UNIVERSIDADE DE SÃO PAULO

FACULDADE DE FILOSOFIA, LETRAS E CIÊNCIAS HUMANAS

DEPARTAMENTO DE HISTÓRIA

PROGRAMA DE PÓS-GRADUAÇÃO EM HISTÓRIA SOCIAL

Lucas Ferreira de Lara

A Música Instrumento: O Padre Antônio Sepp, S.J., e as práticas musicais nas reduções jesuíticas (1691-1733)

Versão Corrigida

São Paulo

2015 
UNIVERSIDADE DE SÃO PAULO

FACULDADE DE FILOSOFIA, LETRAS E CIÊNCIAS HUMANAS

DEPARTAMENTO DE HISTÓRIA

PROGRAMA DE PÓS-GRADUAÇÃO EM HISTÓRIA SOCIAL

\section{A Música Instrumento: O Padre Antônio Sepp, S.J., e as práticas musicais nas reduções jesuíticas (1691-1733)}

Dissertação apresentada ao Programa de PósGraduação em História Social do Departamento de História da Faculdade de Filosofia, Letras e Ciências Humanas da Universidade de São Paulo, para a obtenção do título de Mestre em História Social.

Orientador: Prof. Dr. Carlos Alberto de Moura Ribeiro Zeron

Versão Corrigida

De acordo:

São Paulo

2015 


\section{FOLHA DE APROVACÃO}

Nome: LARA, Lucas Ferreira de

Título: A Música Instrumento: O Padre Antônio Sepp, S.J., e as práticas musicais nas reduções jesuíticas (1691-1733)

Dissertação apresentada ao Programa de Pós-Graduação em História Social do Departamento de História da Faculdade de Filosofia, Letras e Ciências Humanas da Universidade de São Paulo, para a obtenção do título de Mestre em História Social.

Aprovado em:

\section{BANCA EXAMINADORA}

Prof(a). Dr(a).

Instituição: Julgamento:

Assinatura:

Prof(a). Dr(a).

Instituição: Julgamento:

Assinatura:

Prof(a). Dr(a).

Instituição: Julgamento:

Assinatura: 
Aos meus pais, Orlando e Martha, por terem me ensinado o mais importante 


\section{AGRADECIMENTOS}

Em primeiro lugar, agradeço ao meu orientador, Prof. Carlos Zeron, pelo cuidado demonstrado com cada página deste trabalho, por todas as críticas, sugestões e indicações. Agradeço pela confiança, sinceridade e por nossas conversas e batepapos.

Às professoras Maria Cristina Bohn Martins e Eliane Cristina Deckmann Fleck, pelo carinho e por todo incentivo dado a esta pesquisa, mesmo quando ela ainda não passava de uma ideia.

Aos professores Cacá Machado, José Geraldo, Marcos Antonio de Moraes, Marta Amoroso e Paulo Castagna, por todas as contribuições e indicações bibliográficas.

Aos colegas de grupo de estudos, por nossas discussões e valiosas reflexões que enriqueceram, e muito, esta pesquisa. Agradeço a companhia de todos vocês.

Aos amigos Diego Elias dos Santos e Marcus Baccega, por estarem sempre presentes. Obrigado pelo auxílio em todos os momentos e em todos os sentidos.

Aos amigos Carolina Candido, Daniela Chahin Baraúna, Elton Alves, Felipe Rocha, Fernanda Prado, Filipe Nobre Figueiredo, Joyce Pais, Lucas Torigoe, Lucia Esteves, Maiara Ariadne Leones, Rodrigo Lazaresko Madrid e Vinícius Rizzato, pela amizade, pelo companheirismo de todos os dias e pelas contribuições, das mais variadas, a esta pesquisa. Obrigado por tudo.

Ao amigo e professor de música Rafael Vitor Barbosa, pela paciência e generosidade.

Aos amigos do Museu da Pessoa, pelo apoio e compreensão sem os quais esta pesquisa não aconteceria.

Aos meus irmãos, Tiago e Fernanda, companheiros de toda uma vida.

Por fim, agradeço a minha companheira, Mariana Carvalho de Oliveira Rodriguez, pela paciência nos momentos difíceis e apoio incondicional. Obrigado por toda a cumplicidade, incentivo, amizade e amor. Sem você, nada seria possível.

\section{O presente trabalho foi realizado com apoio do CNPq, Conselho Nacional de Desenvolvimento Científico e Tecnológico - Brasil.}


si en las maracas y en las flautas ya estuvo la voz de su Dios, ¿por qué no estaría también en las cajas de los violines, en el seno de las arpas, en el vientre de las campanas, tal como lo enseñaron los Padres y ellos mismos ya habían experimentado?

Bartomeu Melià S.J. 


\section{RESUMO:}

LARA, Lucas Ferreira de. A Música Instrumento: O Padre Antônio Sepp, S.J., e as práticas musicais nas reduções jesuíticas (1691-1733). 2015. 145 f. Dissertação (Mestrado) - Programa de Pós-Graduação em História Social, Faculdade de Filosofia, Letras e Ciências Humanas, Universidade de São Paulo, São Paulo, 2015.

Durante mais de cento e cinquenta anos os missionários jesuítas conviveram, no território da Província Jesuítica do Paraguai, com os índios Guaranis, Guayanás, Mbayás, Chiquitos entre outros. Cientes da multiplicidade de forças em jogo, os padres da Companhia de Jesus buscaram expandir seu poder de influência e atuação por meio da conversão e, posteriormente, da redução dos índios paraguaios.

Neste contexto, os jesuítas precisaram se utilizar de uma gramática civilizatória de amplitude não restrita à cultura europeia. Se, por um lado, os elementos de sua contribuição clerical-pastoral eram, por óbvio, europeus, era necessário encontrar - ou mesmo desenvolver - uma linguagem em comum, uma sintaxe que permitisse a constituição de uma gramática simbólico-religiosa compartilhada. Para o Pe. Antônio Sepp S.J. (1655-1733), fundador da missão de São João Batista e atuante em diversas outras, tratou-se principalmente da música.

Este missionário inaciano, mas também os músicos indígenas formados por ele, são os sujeitos deste trabalho. Em um ambiente de profundas transformações, marca das reduções jesuíticas, a prática musical garantiu papel de destaque a estes atores sociais, que acabaram compondo um grupo diferenciado graças, principalmente, às suas habilidades técnicas.

Palavras-chave: Música. Companhia de Jesus. Missões Jesuíticas 


\section{ABSTRACT:}

LARA, Lucas Ferreira de. The Music as Instrument: The priest Antônio Sepp SJ and the musical practicies in the jesuit reductions (1691-1733). 2015. $145 \mathrm{f}$. Dissertação (Mestrado) - Programa de Pós-Graduação em História Social, Faculdade de Filosofia, Letras e Ciências Humanas, Universidade de São Paulo, São Paulo, 2015.

For over one hundred and fifty years, jesuit missionaries lived in the territory of the Jesuit Province of Paraguay, with the Guarani, Guayanas, Mbayás, Chiquitos among others indians groups. Aware of the multitude of forces at play, the Company of Jesus priests sought to expand their power of influence and action by converting and subsequently reducing the paraguayan indians.

In this context, the jesuits needed to use a civilizing grammar not restricted to european culture amplitude. If the elements of their clerical and pastoral contributions were, obviously, europeans, on the other hand they had to find - or even develop - a common language, a syntax that would allow the creation of a shared symbolicreligious grammar. For the priest Antonio Sepp SJ (1655-1733), founder of the São João Batista mission and active in several other, it was the music.

This jesuit, but also the indigenous musicians formed by him, are the subject of this work. In an environment of profound transformations, aspect of the jesuit reductions, musical practice secured prominent role of these social actors, who had composed a distinct group thanks mainly to their technical skills.

Keywords: Music. Company of Jesus. Jesuit Missions 


\section{LISTA DE SIGLAS}

AR-AGN.DE: Archivo General de La Nación Argentina 


\section{SUMÁRIO}

INTRODUÇÃO _ p. 12

1 MISSÕES EM DEBATE__ p. 20

1.1 Antes de mais nada __ p. 20

1.2 Linhas divisórias_ p. 21

1.3 Apologistas e simpatizantes

1.3.1 Membros da Companhia de Jesus __ p. 23

1.3.2 Simpatizantes _ p. 29

1.4 Os contrários p. p. 33

1.5 Crítica Histórica _ p. 36

1.6 Algumas considerações _ p. 45

2 ANTÔNIO SEPP: A TRAJETÓRIA DE UM MISSIONÁRIO___ p. 48

2.1 A Fase Europeia (1655-1691)_ p. 49

2.1.1 A música nos colégios da Companhia de Jesus __ p. 55

2.1.2 Entrada para a Companhia de Jesus, formação e atuação como professor p. 57

2.1.3 Solicitação para ir às Missões __ p. 62

2.1.4 Cartas p. 65

2.1.5 Os escritos de Sepp p. 67

2.2 A Fase Americana (1691-1733)_ p. 69

2.2.1 Travessia oceânica e primeiras impressões da América__ p. 71

2.2.2 A falta de ferro ___ p. 78

2.2.3 Criação de gado _ p. 81

2.2.4 Tutela e organização do trabalho __ p. 86

2.2.5 Castigos: violência e consentimento __ p. 88

2.2.6 O missionário experiente __ p. 94

3 A MÚSICA INSTRUMENTO _ p. 97

3.1 A música missioneira _ p. 98

3.2 A importância da música para os indígenas __ p. 103

3.3 Ensino musical _ p. 112

3.4 Fabricação de instrumentos __ p. 117

3.5 Instrumento de Celebração _ p. 119

3.6 Instrumento de regência temporal e laboral __ p. 123 
3.7 Instrumento de diferenciação social p. 127

CONSIDERAÇÕES FINAIS p. 136

REFERÊNCIAS p. 142 


\section{INTRODUÇÃO}

A música e o universo missioneiro

Através do Tratado de Tordesilhas firmado entre Portugal e Espanha em 1494, estabeleceram-se limites para as possessões decorrentes das descobertas dos países ibéricos, inseridas no contexto do capitalismo mercantil. ${ }^{1}$ A ocupação colonial do continente americano deu-se a partir e pelo litoral atlântico no caso dos portugueses e a partir do Caribe e ao longo da costa pacífica pelos espanhóis. A Coroa espanhola, de acordo com o tratado, procurou também tomar posse e se fixar na região do Rio da Prata e seus afluentes, onde os caminhos fluviais possibilitavam um rápido escoamento das riquezas produzidas no Peru.

Além da ocupação promovida pelas duas Coroas, também se dirigiram à América diferentes ordens religiosas católicas, num período em que a Igreja passava pela Contra-Reforma, promovida a partir do Concílio de Trento (1545-1563). ${ }^{2}$ Nesse processo é possível destacar a Companhia de Jesus, ordem fundada por Inácio de Loyola e criada oficialmente em 1540 através da Bula Regimini militantis Ecclesiae, do papa Paulo III. Com o objetivo central de propagar a palavra de Cristo aos pagãos, os jesuítas foram levados a outros continentes. Na América, a Companhia teve importante papel na relação com os povos nativos, seja por ter sido responsável pelos contatos iniciais com grande parte dos povos indígenas, seja por intermediar o contato posterior entre índios, colonos e a administração colonial. Por essa ação mediadora, foi fundamental na consolidação dos novos territórios, promovendo a construção de inúmeros colégios, igrejas e povoados, por meio de missões e reduções, utilizadas na conquista espiritual dos indígenas.

Foi no período da União Ibérica (1580-1640) que se iniciaram as tentativas da Companhia de Jesus de levar a palavra de Deus ao que os padres acreditavam ser uma "rica mina de almas". Somente em 1585 chegaram às proximidades do rio Paraguai os primeiros padres jesuítas, provenientes do Peru, e em 1587, do Brasil. O historiador Aurélio Porto destaca três missionários como sendo o tripé básico da formação das primeiras reduções no Prata, em Guairá e no Itatim: o catalão Manuel Ortega, o

\footnotetext{
${ }^{1}$ PRADO JR., Caio. Formação do Brasil Contemporâneo. São Paulo: Editora Brasiliense, 1976. pp. 22-25.

${ }^{2}$ DAVIDSON, N. S. A Contra-Reforma. São Paulo: Editora Martins Fontes, 1991. pp. 36-37.
} 
português João Saloni e o irlandês Tomaz Field. ${ }^{3}$

Em 1604, foi constituída a Província Jesuítica do Paraguai, independente das Províncias do Peru e do Brasil. Na região do Paraná ${ }^{4}$ a primeira missão foi fundada pelos padres Marcial de Lorenzana e Francisco de San Martin, em 1610, tendo sido denominada Santo Inácio Guaçú (distante 185 km de Assunção). Essa redução se desenvolveu de tal forma que por muitos anos não apenas se tornou a mais importante da região, como também o ponto de partida para a fundação das demais. A estrutura missioneira, principalmente na região da Provincia Paracuaria, diferenciou-se do exploratório sistema colonial escravocrata e, segundo o historiador Arno Kern, concedeu uma sobrevida de mais de um século às populações indígenas reduzidas. ${ }^{5}$

Durante mais de cento e cinquenta anos os missionários jesuítas conviveram com os índios Guaranis, Guayanás, Mbayás, Chiquitos entre outros, em diferentes regiões. Estruturaram, neste contato, um sistema reducional ${ }^{6}$ que constituiu-se em uma rede de trinta povoados, articulados por estradas, portos e ligações fluviais; entre estâncias de gado, lavouras e ervais, chegando a envolver cerca de 150 mil índios e 457 jesuítas em seu período de apogeu, entre 1735 e $1750{ }^{7}$

Desta forma, é preciso estar atento a um universo formado por grupos bastante complexos e heterogêneos (jesuítas, diversos povos indígenas, colonos e coroas ibéricas, com todo seu aparato administrativo) que se relacionaram em diversos níveis e instâncias no centro da esfera reducional, espaço de interesse das partes envolvidas.

Os missionários jesuítas, cientes desta multiplicidade de forças em jogo, buscaram expandir seu poder de influência e atuação por meio da conversão e, posteriormente, da redução dos índios paraguaios. Ao sacramentar uma instância simbólica de contato, atrito e intercâmbio de elementos e práticas culturais entre europeus e autóctones americanos, os membros da Companhia de Jesus precisaram traduzir uma "tradição religiosa ocidental para uma cultura que não participava

\footnotetext{
${ }^{3}$ PORTO, Aurélio. História das Missões Orientais do Uruguai. Rio de Janeiro: Imprensa Nacional, 1943. p. 26. Disponível em: http://ufdc.ufl.edu/AA00011461/00001. Acesso em: 05/03/2014.

4 A região não corresponde ao atual estado do Paraná, e sim às proximidades dos rios Paraná e Paraguai, mais precisamente na fronteira entre os atuais países Paraguai e Argentina.

${ }^{5}$ KERN, Arno. Utopia e missões jesuíticas. Porto Alegre: Ed. Universidade/UFRGS, 1994. p. 76.

${ }^{6}$ Faz-se necessária uma distinção conceitual. Utilizaremos os adjetivos missioneiro, missional e reducional para qualificar termos referentes às reduções jesuíticas. Já a designação missionária será utilizada para caracterizar as ações dos jesuítas, de acordo com o projeto de expansão da fé cristã desenvolvido pela Companhia de Jesus.
}

${ }^{7}$ Cf. FURLONG, Guillermo S.J. Missiones y sus Pueblos de Guaranies. Buenos Aires: Imprenta Balmes, 1962. 
dela." ${ }^{8}$ Neste contexto, ao trazer para os indígenas um repositório de práticas cultuais, agrícolas, arquitetônicas e um sistema de balizas morais vinculantes, os jesuítas precisaram se utilizar de uma gramática civilizatória de amplitude não restrita à cultura europeia. Se, por um lado, os elementos de sua contribuição clerical-pastoral eram, por óbvio, europeus, era necessário encontrar - ou mesmo desenvolver - uma linguagem de denominador comum, uma sintaxe que permitisse a constituição de uma gramática simbólico-religiosa compartilhada, composta de semantemas indígenas e europeus. Para o Pe. Antônio Sepp (1655-1733), fundador da missão de São João Batista e atuante em diversas outras na região da Província Jesuítica do Paraguai, tratou-se principalmente da música.

Este missionário inaciano, mas também os músicos indígenas formados por ele, são os sujeitos deste trabalho. Em um ambiente de profundas transformações, marca das reduções jesuíticas, a prática musical garantiu papel de destaque a estes atores sociais, que acabaram compondo um grupo diferenciado graças, principalmente, às suas habilidades técnicas.

As práticas musicais desempenham papel relevante na compreensão das sociedades, uma vez que marcam presença em todas as culturas. No entanto, torna-se extremamente difícil o trabalho com a música tendo o olhar preso a uma única disciplina ou campo de conhecimento. Contribuições de áreas como Musicologia, História, Sociologia e Antropologia são alicerces necessários a um estudo de fundamentação cultural, como nos aponta a musicóloga Fátima Graciela Musri:

La intersección entre la musicología y la historia social ya cruzadas con otros cuerpos conceptuales, da por resultado el estudio de la historia social de la música. Por conseguiente se generan temas novedosos que requieren de nuevos enfoques y métodos, como la etnomusicologia histórica o la historia de la música de aquellos músicos no reconocidos como cimeros. ${ }^{9}$

\footnotetext{
${ }^{8}$ AGNOLIN, Adone. O governo das almas indígenas: missão jesuítica e ritualidade indígena (séc. XVI-XVII). In: SOUZA, Laura de Mello e; FURTADO, Júnia Ferreira; BICALHO, Maria Fernanda (orgs.) O governo dos povos. São Paulo: Alameda, 2009, p. 214.

9 MUSRI, Fátima Graciela. Relaciones conceptuales entre musicologia e historia: análisis de una investigación musicológica desde la teoría de la historia. In: Revista musical chilena. v.53, n. 192. Santiago, 1999.

Disponível em:
} http://www.revistamusicalchilena.uchile.cl/index.php/RMCH/article/viewFile/12803/13090. Acesso em: 20/04/2015. 
Fontes

As fontes primárias de informação disponíveis sobre as missões são constituídas principalmente por documentos produzidos pelos padres da Companhia de Jesus, em suas cartas e relatórios periódicos, pela correspondência oficial espanhola e portuguesa, assim como por relatos e diários de viajantes. O músico e pesquisador Marcos Holler afirma que mesmo tendo a atuação dos jesuítas na América Portuguesa se iniciado mais de meio século antes do que na América Espanhola, esta segunda apresenta, ao contrário da primeira, abundância de informações a respeito da prática musical nas suas reduções, desde a chegada dos primeiros missionários em 1610 até sua expulsão em 1767: "Diferentemente do que ocorre no Brasil, nas reduções da América Espanhola foram descobertos instrumentos musicais e partituras da atuação jesuítica, muitas já publicadas e gravadas."10

A principal fonte primária utilizada neste trabalho consiste no mais antigo documento escrito sobre as reduções junto ao rio Uruguai e, consequentemente, sobre parte do Rio Grande do Sul. Viagem às Missões Jesuíticas foi baseada em cartas escritas pelo padre Antônio Sepp em 1691 e dirigidas, em grande parte, a seu irmão Gabriel von und zu Rechegg. ${ }^{11}$ Além dela, utilizamos também a obra Trabalhos apostólicos, sendo que as cartas que o constituem foram escritas por Sepp em 1700.

Complementa as fontes deste trabalho o volume $\mathrm{V}$ dos Manuscritos da coleção De Angelis, com introdução, notas e sumário por Jaime Cortesão. Ele apresenta uma série de correspondências jesuíticas e da administração colonial ibérica que servirão de complemento às informações que aparecem nas cartas do Pe. Antônio Sepp, auxiliando na construção de um cenário mais completo. Com o mesmo intuito, apresentaremos documentos encontrados no Archivo General de la Nación Argentina e o tomo I da obra Organización Social de las Doctrinas Guaraníes de la Compañia de Jesús. ${ }^{12}$

Por fim, utilizamos a Carta Relación de 1747, do padre jesuíta José Cardiel,

${ }^{10}$ HOLLER, Marcos Tadeu. Os jesuítas e a música no Brasil colonial. Campinas: Editora da Unicamp, 2010, p. 205.

${ }^{11}$ HARNISCH, Wolfgang Hoffmann. Introdução. In: SEPP, Antônio. Viagem às Missões Jesuíticas e Trabalhos apostólicos [Introdução e notas de Wolfgang Hoffmann Harnisch; tradução de Reymundo Schneider e dos alunos da Companhia de Jesus, em Pareci]. São Paulo: Martins, Edusp, 1972, p. XLVII. Obs: A numeração das páginas, após a Introdução, deixa de ser grafada em algarismos romanos e inicia-se com 1 .

${ }^{12}$ Organización Social de las Doctrinas Guaraníes de la Compañia de Jesús. Tomo I. Barcelona: Gustavo Gili, 1911. Disponível em: http://bdh-rd.bne.es/viewer.vm?id=0000012629\&page=1. Acesso em: 01/05/2014. 
especialmente o capítulo Del Gobierno Eclesiástico de los Indios - De sus Costumbres Cristianos. Nela aparecem diversas referências ao padre Sepp, então já falecido, que nos ajudam a dimensionar sua importância e as transformações que impulsionou na região. ${ }^{13}$

Tendo em vista que esses documentos foram produzidos, quase que totalmente, pelos próprios missionários, foi preciso estar atento ao fato de que a "perspectiva indígena aparece de maneira muito sutil, nas entrelinhas e sempre filtrada pela ótica dos interesses de quem a documenta." 14 Vale ressaltar que o conjunto das fontes foi tratado como uma narrativa na qual diversas vozes estão depositadas, em contraponto ou em uníssono, e em diferentes tempos. A adesão ao uso dos símbolos cristãos ou a participação, como músicos, em cerimônias cristãs, nos deram ideia da dinâmica histórica pela qual os indígenas procuravam instrumentos de afirmação política no mundo colonial, construindo um universo simbólico compartilhado por outros atores sociais e reconstruindo com estes uma nova hierarquia das relações sociais e de poder. De qualquer forma, concordamos com a historiadora Daniela Ribeiro Pereira quando afirma que "o cotejamento de fontes não necessariamente inéditas continua sendo a base de uma análise crítica do tema, bem como o uso acurado de conceitos utilizados nos textos de época." 15

As práticas musicais não são algo meramente abstrato e restrito aos sentidos, mas trazem consigo um grau de materialidade que é fundamental em nosso caso. A música é resultado da ação humana. Antônio Sepp, por exemplo, estudou música desde criança, tendo se aperfeiçoado durante os anos de formação jesuíta, o que atesta a existência de uma rede de produção do conhecimento musical, de ensino. Ensino este desempenhado pelo próprio inaciano durante a rotina nas reduções, formando profissionais capazes de executar a música litúrgica ou mesmo profana, dependendo da necessidade ou da demanda de um "público" em formação. O missionário, por sua vez, tomava por base partituras compostas por músicos europeus e copiadas por neófitos especialmente designados para isso, com o objetivo de disseminar o ensino

\footnotetext{
${ }^{13}$ FURLONG, Guillermo S.J. José Cardiel y Su Carta Relación. Libreria del rio de la Plata. Buenos Aires, 1953.

${ }^{14}$ MONTERO, Paula (org.). Deus na aldeia: missionários, índios e mediação cultural. São Paulo: Globo, 2006. p. 13.

15 PEREIRA, D. R. "Si soy misionero es porque canto, bailo y toco música": para uma história social da música na Provincia Paracuaria (1680-1768). 2011. 164f. Dissertação de Mestrado. PUCRS, Porto Alegre. 2001. p. 16. Disponível em: http://tede.pucrs.br/tde_busca/arquivo.php?codArquivo=3678. Acesso em: 15/04/2015.
} 
musical para outras reduções. Além disso, Sepp sabia confeccionar instrumentos, tendo ensinado o ofício a seus pupilos paraguaios.

Em resumo, a materialidade da música torna-se perceptível na ação de professores, compositores, luthiers, copistas e público, assim como nos instrumentos confeccionados e na música posta em papel. Através de sua análise, poderemos observar aspectos que consideramos relevantes para o contexto missioneiro, como a divisão e organização do trabalho nas missões ou a nova noção de temporalidade introduzida pelos missionários.

No que diz respeito à demonstração do espaço ocupado pela música nas reduções, por exemplo, não salientaremos apenas o ensino musical ministrado para os neófitos, mas também aspectos que concernem à materialidade implícita na prática musical. Tanto a compra e confecção de instrumentos musicais quanto os benefícios materiais obtidos pelos índios músicos também receberão atenção, jogando luzes sobre pontos como o abastecimento interno de mercadorias e a circulação de bens entre as missões.

No entanto, textos do musicólogo Leonardo Waisman destacando o fato de que, mais do que pautas musicais, eram as execuções locais que definiam a singularidade das músicas tocadas nas missões, nos fizeram refletir sobre a contribuição real que uma análise de partitura, ou a comparação entre algumas delas, traria a esta pesquisa. E isto porque nosso objetivo é a compreensão das relações estabelecidas através da manifestação musical. O que nos importa é mais o processo que o produto. ${ }^{16}$

Soma-se a isso o fato de termos tido contato com trabalhos de musicólogos que há décadas se debruçam sobre a análise de partituras sobreviventes das missões americanas, como Piotr Nawrot, Paulo Castagna e o já citado Leonardo Waisman, e que de forma muito competente apresentam informações detalhadas destas fontes, além de apontarem para os muitos obstáculos presentes em seu estudo, como as questionáveis caracterizações de autoria e estilo. Há também outros problemas, de ordem prática, como as traduções de termos ligados à linguagem musical e presentes não só nas partituras, mas em correspondências e obras sobre o tema. O músico Jorge Hirt Preiss, por exemplo, enfatizou os equívocos nas traduções das obras,

${ }^{16}$ WITTMANN, Luisa T. Flautas e maracás: música nas aldeias jesuíticas da América Portuguesa (XVI-XVII). 2011. 266f. Tese de Doutorado em História. UNICAMP, Campinas. 2011. p. 107. Disponível em: www.bibliotecadigital.unicamp.br/document/?down=000802385. Acesso em: 13/04/2015. 
especialmente no que diz respeito a instrumentos musicais, tendo apresentando casos de erros anacrônicos, de supressão de dados ou inclusão deliberada e sem embasamento. ${ }^{17}$

Nossa proposta centrou-se, então, em uma análise social das práticas musicais e da cultura material relacionada a elas. Dessa forma, a música não foi tratada como objeto principal, mas como instrumento para compreender relações sociais que se deram através dos sons. ${ }^{18}$ É a própria prática musical, vista como um processo histórico que ocorreu em determinado recorte espacial e temporal, que produziu resultados e permanece latente nas culturas contemporâneas.

Estrutura dos capítulos

Esta pesquisa está dividida em três capítulos. É importante, desde já, salientar que o objetivo não foi esgotar os questionamentos acerca da utilização da música nas missões jesuíticas e das múltiplas relações e negociações advindas dela. Apenas buscamos contribuir com o debate quebrando um pouco as visões tradicionais e cristalizadas sobre o tema, suscitando novas reflexões.

No primeiro capítulo apresentaremos um cotejo entre os diversos trabalhos já realizados sobre as missões jesuíticas. Serão abordadas pesquisas de historiadores, sociólogos, antropólogos, musicólogos, entre outros, com o objetivo de demonstrar a variedade de perspectivas sobre o assunto.

O segundo capítulo apresenta um verdadeiro jogo de escalas, onde a vida de Antônio Sepp serve de guia para a compreensão de determinados aspectos da mentalidade da Contra-Reforma, da organização da Companhia de Jesus, da preparação de seus missionários, além, é claro, de permitir um olhar sobre os papéis da música em sua vida. Da mesma forma, basear-nos-emos nos escritos de Sepp para traçar um histórico de sua atuação como missionário paraguaio, analisando, a partir de suas experiências, a estrutura das reduções jesuíticas e sua organização política e econômica.

No terceiro capítulo, central nesta dissertação, buscaremos demonstrar o

\footnotetext{
${ }^{17}$ PREISS apud PEREIRA, D. R. Por uma História da Música das Missões - Entrevista com Jorge Hirt Preiss. Realizada em 04/05/2009. Disponível no CPHO-PUCRS.

18 WITTMANN, Luisa T. Flautas e maracás: música nas aldeias jesuíticas da América Portuguesa (XVI-XVII). 2011. 266f. Tese de Doutorado em História. UNICAMP, Campinas. 2011. p. 22. Disponível em: www.bibliotecadigital.unicamp.br/document/?down=000802385. Acesso em: $13 / 04 / 2015$.
} 
espaço ocupado pela música nas reduções paraguaias. Tentaremos mostrar que a utilização da música foi fundamental, enquanto instrumento simbólico e prático, para as traduções culturais, aproximações, disputas e negociações ocorridas dentro do contexto missioneiro, sendo, por isso, importante ferramenta para o domínio exercido pela Companhia de Jesus no território colonial espanhol.

Defenderemos a hipótese de que a prática musical agiu como um facilitador da assimilação de elementos culturais exógenos aos nativos, servindo, portanto, como um verdadeiro "instrumento", executado pelos padres da Companhia para auxiliar no controle das populações reduzidas, de cujos braços necessitavam na manutenção do território e sucesso das missões e cujas almas buscavam salvar. No entanto, buscaremos mostrar que os indígenas viram na música um poderoso meio de obtenção de benefícios e privilégios neste novo universo no qual estavam inseridos.

Por fim, nas considerações finais trabalharemos com o binômio violência e consentimento, apresentado pelo antropólogo Maurice Godelier, na tentativa de propor uma reflexão sobre as relações sociais estabelecidas entre indígenas convertidos e missionários jesuítas no universo das reduções paraguaias. Nossa intenção também é demonstrar como o surgimento de novas formas de dominação e exploração implicou no aparecimento de grupos especializados, com funções de maior prestígio dentro da estrutura política e econômica missioneira. É este o caso dos índios músicos. 


\section{MISSÕES EM DEBATE}

\subsection{Antes de mais nada}

O tema das reduções jesuíticas e a atuação dos missionários da Companhia de Jesus junto aos indígenas, por sua importância fundamental no contexto colonial, sempre despertou avaliações e interpretações inflamadas. Na medida em que envolveu interesses de setores concorrentes como as duas Coroas ibéricas, a Igreja Católica e os povos nativos, relacionados a territórios com fronteiras ainda maleáveis, comparece na historiografia de cada país e na memória das áreas envolvidas, sob diferentes versões e interpretações, nas várias disciplinas interessadas em seu estudo, como por exemplo a História, a Geografia e a Antropologia.

Nos próximos capítulos, nos lançaremos à análise da formação e da atuação do Pe. Antônio Sepp como missionário, do universo missioneiro e da presença e papel da música neste contexto. Porém, antes, cabe fazermos uma apreciação crítica de alguns estudos que serviram de base para esta pesquisa e que focalizaram vários elementos do trabalho catequético dos jesuítas na América do Sul. ${ }^{19}$ Nosso objetivo é mostrar os diferentes enfoques dados pelos especialistas em relação à atuação missionária. Buscaremos também demonstrar que, embora existam muitos trabalhos sobre o assunto, eles encontram-se dispersos em suas áreas de conhecimento devido aos recortes nacionais ou regionais adotados pela historiografia, o que muitas vezes tornase um obstáculo a novas pesquisas.

Tivemos dificuldade em encontrar várias das obras utilizadas nesta dissertação. Embora a bibliografia de alguns livros nos levasse a outras obras, que remetiam a inúmeros outros estudos e assim por diante, poucos deles, mesmo entre os considerados clássicos, estavam disponíveis em bibliotecas brasileiras. $\mathrm{O}$ surgimento deste capítulo deveu-se, em grande parte, ao desejo e à necessidade de reunir referências de alguns trabalhos sobre o tema. Nesta tarefa, a internet foi uma ferramenta essencial, na localização de obras digitalizadas e disponíveis para consulta on-line, na obtenção de publicações existentes apenas em outros países e no contato com alguns autores com a intenção de encontrar soluções para o impasse.

Portanto, fizemos questão de buscar, de acordo com a disponibilidade, versões digitais que possibilitem o acesso via links (colocados sempre nas notas de rodapé) já

${ }^{19}$ Falamos em América do Sul pois, no recorte selecionado, o tema das fronteiras é permeável, oscilante e palco de distintas dinâmicas que antecedem a constituição dos Estados-Nação. 
que, como será possível notar pela leitura deste capítulo, a esmagadora maioria dos estudos relacionados às missões encontra-se em espanhol e inglês, sem publicações no Brasil. Esperamos, assim, contribuir para o surgimento de novos estudos sobre as missões, especialmente em língua portuguesa.

\subsection{Linhas divisórias}

Em um primeiro momento, nossa ideia era apresentar os trabalhos divididos em quatro grandes linhas: apologéticos à Companhia, anti-jesuítas, história econômica das missões e enfoques culturais. No entanto, à medida que analisávamos cada estudo, percebemos que a divisão entre aspectos econômicos e culturais seria um erro, já que existem trabalhos de história econômica das missões que defendem a atuação dos jesuítas e outros que a condenam. O mesmo pode-se dizer dos textos que focam em elementos culturais. Demo-nos conta de que uma divisão tão esquemática não traria benefícios ao nosso trabalho, já que essas linhas de pesquisa são extremamente permeáveis. Como buscamos interpretar a utilização da música no contexto missionário, portanto um enfoque de História da Cultura, percebendo sua inserção na estrutura das reduções, o que inclui aspectos políticos, econômicos e sociais, não faria sentido apresentar cultura e economia como elementos estanques. Longe de serem paralelas, estas duas linhas se entrecruzam em diversos pontos.

Pelo foco desta dissertação, daremos maior atenção aos estudos envolvendo manifestações culturais surgidas no contato entre indígenas e missionários, que são inúmeras e bastante variadas. Pode-se dizer que os trabalhos acerca da música, pinturas e representações gráficas, rituais e celebrações, arquitetura, dança e teatro nas missões, têm crescido consideravelmente nos últimos vinte anos. Cada vez mais, pesquisadores têm se dado conta do valor dos aspectos culturais para a compreensão da realidade histórica no contexto colonial. Trabalhos recentes, inclusive, fazem referência a uma nova corrente de estudos sobre o tema, denominada "New Missions History" ${ }^{20}$ que, além de apresentar uma abordagem cultural, vem tentando superar as visões tradicionais, recuperando a perspectiva nativa e certa capacidade estratégica

\footnotetext{
${ }^{20} \mathrm{Cf}$. WILDE, Guillermo. Poderes del ritual y rituales del poder: un análisis de las celebraciones en los pueblos jesuíticos de Guaraníes. In: Revista Española de Antropologia Americana. 2003, pp. 203-229. Disponível em: http://www.google.com.br/search?q=guillermo+wilde+poderes+del+ritual\&ie=utf- $8 \&$ oe $=$ utf$8 \& \mathrm{aq}=\mathrm{t} \& \mathrm{rls}=$ org.mozilla:en-US:official\&client=firefox-a\&gfe_rd=cr\&ei=RvARUifCMai8wfN0oDoAQ. Acesso em: 01/03/2014
} 
dos indígenas.

Todavia, não podemos nos esquecer de importantes trabalhos anteriores que serviram de base para os que agora surgem. Como o tema de nossa pesquisa diz respeito à música, trabalhos neste âmbito receberam maior destaque, embora outras vertentes também tenham sido abordadas.

O antropólogo Guillermo Wilde traz uma interessante classificação acerca dos trabalhos existentes sobre as missões jesuíticas. Ao refletir sobre a importância das celebrações e rituais no contexto das reduções, Wilde aponta que:

La fuerte tradición de historiadores apologistas, haciéndose eco acríticamente de las fuentes jesuitas de los siglos XVII y XVIII, entendió la atracción indígena hacia los regalos y el ceremonial como una actitud pueril, vacía de contenidos socioculturales. Por su parte, los historiadores antijesuitas, tomando en cuenta un conjunto diferente de fuentes, simplemente dejaron de lado este aspecto de la vida reduccional. Por último, los trabajos más recientes de la historia económica misionera, pese al rigor que los caracteriza, han tendido a apartar del análisis la dimensión ritual y simbólica, considerándola como un elemento de la superestructura, es decir, una herramienta oculta de la opresión económica. ${ }^{21}$

Ao realizar esta divisão, Wilde leva em conta apenas o aspecto cultural presente, ou não, nestes trabalhos. No decorrer de seu artigo, defende uma linha de pensamento mais voltada para a cultura. São trabalhos acerca da arquitetura, arte, cerimônias, música e outros elementos importantes para a compreensão do universo missioneiro e suas estruturas de poder. Colocamo-nos nesta categoria. Embora nosso objetivo central seja o estudo da música e seus papéis na relação índios-missionários surgida nas reduções, consideramos fundamental o estudo de aspectos políticos e econômicos deste contexto. Da mesma forma, é essencial para nós compreender melhor os agentes dessa relação, evidenciando seus interesses nestas trocas culturais e como reagiram às profundas transformações acarretadas por elas.

Optamos, por fim, por dividir os trabalhos aqui apresentados em três categorias: Apologéticos e simpatizantes, Contrários e Crítica Histórica. Esta divisão, embora possa soar simplória e um pouco ingênua, é profundamente representativa dos estudos sobre as missões, já que a quase totalidade dos pesquisadores, sejam eles

${ }^{21}$ Cf. WILDE, Guillermo. Poderes del ritual y rituales del poder: un análisis de las celebraciones en los pueblos jesuíticos de Guaraníes. In: Revista Española de Antropologia Americana. 2003, p. 204. Disponível em: http://www.google.com.br/search?q=guillermo+wilde+poderes+del+ritual\&ie=utf8\&oe=utf-8\&aq=t\&rls=org.mozilla:en-US:official\&client=firefox-a\&gfe_rd=cr\&ei=RvARUifCMai8wfNOoDoAQ. Acesso em: 01/03/2014 
historiadores, musicólogos, antropólogos, arquitetos, entre outros, ou situa-se no binômio "pró e contra" ou tenta ao máximo, algumas vezes sem sucesso, demonstrar imparcialidade nesta discussão, apresentando pontos que consideram positivos e negativos da atuação dos missionários junto aos ameríndios. Evidentemente, não consideramos esta divisão como definitiva e ideal para pesquisas com temáticas diferentes, tendo clara a ideia de que as categorias criadas nada mais são do que instrumentos de análise. Nossa intenção foi elucidar e problematizar, em um primeiro momento, a antítese rígida em que incorreram, de modo reiterado, muitos dos trabalhos até então desenvolvidos.

\subsection{Apologistas e simpatizantes}

A primeira destas categorias é constituída por autores que fazem apologia à ação da Companhia de Jesus junto aos indígenas paraguaios. São eles padres jesuítas ou simpatizantes, incluindo historiadores, teólogos, educadores, entre outros. Seus trabalhos geralmente são marcados por muitos elogios, enaltecendo o esforço, sacrifício, capacidade intelectual e liderança dos inacianos. Tendem a tratar os indígenas como um bloco homogêneo: "bárbaros e infiéis" que, após a ação dos padres da Companhia, se tornam cristãos exemplares, que amam os missionários como a seus pais. A diversidade cultural das várias nações reduzidas não é abordada ou, quando ocorre, aparece de maneira muito superficial. Quanto à crítica das fontes, tendem a utilizá-las como "narrativa de acontecimentos", sem problematizações ou levantamento de hipóteses contrárias ao que o documento apresenta.

\subsubsection{Membros da Companhia de Jesus}

O historiador Antônio Serafim Leite, S.J. (1890-1969), talvez seja o nome mais emblemático para representar esta primeira categoria. Desejando mostrar o que pretendiam os missionários, o que fizeram "na realidade", em que suportes ideológicos se sustentava a instituição a que pertenciam, o padre jesuíta escreve sua História da Companhia de Jesus no Brasil. ${ }^{22}$ A obra levou 18 anos para ser concluída (entre 1932 e 1950) e é uma das maiores referências no estudo da presença e atuação

\footnotetext{
${ }^{22}$ LEITE, Serafim S. J. História da Companhia de Jesus no Brasil. 10 v. in 4. $2^{\text {a }}$ Edição. São Paulo. Edições Loyola, 2004.
} 
dos jesuítas no Brasil. Seu valor reside, sobretudo, na extensa documentação pesquisada. Nos dez volumes de sua obra, Serafim Leite, de forma muito erudita, discorre sobre diversos aspectos da história da Companhia, como, por exemplo, o estabelecimento da Ordem, as atividades nos aldeamentos, a catequese, descrição das províncias, além de um detalhado levantamento de escritores jesuítas do Brasil, contendo informações biográficas e bibliográficas.

Tendo sido escrito com base quase que exclusivamente em documentação da própria Companhia, seu alcance interpretativo acaba limitado, ainda mais pelo tom sempre apologético. Ressalta só o ponto de vista do colonizador, com um enfoque na ação missionária como ferramenta de dominação colonial, engrandecendo a obra da Coroa portuguesa e dos jesuítas, sempre defendidos e louvados.

Há também o caso de trabalhos de cunho biográfico, cujo objetivo é apenas contar a vida e obra de algum ilustre missionário, sem a preocupação com citações, referências e retirando das fontes apenas o que pode "referendar" as qualidades do personagem em questão. Geralmente escritos por padres da Companhia, estes textos apresentam visões cristalizadas e parciais, contribuindo para o debate historiográfico, a nosso ver, apenas pela apresentação de fontes em alguns casos desconhecidas e de acesso, no período de publicação da obra, apenas aos próprios membros da Companhia de Jesus.

O estudo biográfico Pe. Antônio Sepp, SJ - O gênio das Reduções Guaranis, ${ }^{23}$ do padre Arthur Rabuske, S.J. (1924-2010), é um exemplo claro deste tipo de trabalho. Em um capítulo em que se ocupa de desconstruir a visão de que os jesuítas gozavam de vida mansa, Rabuske defende incondicionalmente Antônio Sepp, apresentando trechos de suas cartas em que narra obrigações diárias do missionário, chegando ao extremo de tecer críticas ácidas aos que ousam discordar de sua visão:

Que ainda hoje se considere e se chame de marajá um padre Sepp, não passa de crassa ignorância ou evidente maledicência, sendo ambas de correção obrigatória para quem quiser o qualificativo de pessoa culta. ${ }^{24}$

A contribuição do trabalho do Pe. Arthur Rabuske reside na competente listagem de textos escritos por Sepp e de trabalhos sobre o missionário. Algumas das

\footnotetext{
${ }^{23}$ RABUSKE, Arthur S.J.. Pe. Antônio Sepp, SJ - O Gênio das Reduções Guaranis. São Leopoldo: Editora Unisinos, 2003.

${ }^{24}$ Ibidem, p. 138
} 
cartas do jesuíta foram traduzidas pelo autor e publicadas como anexos em seu livro. Como os originais das correspondências estão em latim ou alemão, localizados em arquivos e bibliotecas europeias, como os da Companhia de Jesus ou de universidades alemãs, a disponibilização deste material em português torna a obra de Arthur Rabuske valiosa para pesquisas sobre os jesuítas inseridos no sistema reducional. Além disso, o pesquisador inaciano ainda contribui com informações retiradas da extensa biografia de Antônio Sepp produzida por outro inaciano, Johann Mayr, ${ }^{25} \mathrm{e}$ não acessível em português ou outras línguas latinas (escrita em alemão).

Outro exemplo deste tipo de trabalho é o 3.000 Guaraníes y un Tirolés, ${ }^{26}$ escrito pelo padre jesuíta Francisco Braumann. Nele, o autor tece um pequeno panorama inicial sobre o surgimento das missões paraguaias a fim de apresentar ao leitor o cenário em que atuará o personagem Antônio Sepp Von Rainegg. ${ }^{27}$ Passa então a narrar sua história, desde o nascimento até a ida ao Novo Mundo como missionário e posterior atuação junto aos índios. Excertos das cartas de Sepp entremeiam a narrativa à medida que o autor as complementa com considerações apologéticas e bastante imaginação. Impossível não notar o tom laudatório presente em toda a obra:

Las reducciones nascidas del sacrificio sin cuento de los misioneros constituyeron oasis de cultura. (...) Tras múltiples fracasos y grandes pruebas, las Reducciones mostraron su eficiencia. Grupos de pueblos que antes se combatían y eliminaban mutuamente, ahora convivían en paz. Se hallaban a las puertas de una nueva cultura, de una estupenda civilización... ${ }^{28}$

A necessidade de transformar o Pe. Sepp em um verdadeiro herói leva a alguns exageros, páginas em que o autor reescreve acontecimentos narrados pelo missionário, carregando fortemente nos detalhes dramáticos. Tudo com o objetivo de encantar o leitor. Exemplo disso é a descrição de um dos assaltos sofridos por Sepp em sua viagem desde o Tirol até o porto de Cádiz, de onde partiria rumo às missões. Segue o relato que encontramos na obra do padre Francisco Braumann. Embora um

\footnotetext{
${ }^{25}$ MAYR, Johann. Anton Sepp: Ein Südtiroler im Jesuitenstaat. Verlagsnstalt Athesia, Bozen, 1988. 480p.

${ }^{26}$ BRAUMANN, Francisco. 3.000 Guaraníes y un Tirolés: Reducciones guaraníticas - Sepp Von Rainegg (1655-1733). Tradução: José Gallinger. Buenos Aires. Editorial Guadalupe. 1981. Título do original alemão: 3000 Indianer und ein Tiroler. Verlag St. Gabriel Steyer Verlag, 1977.

${ }^{27}$ Conforme veremos no próximo capítulo, o sobrenome do Padre Sepp aparece com diferentes grafias em documentos, estudos e publicações. Para mais Cf. RABUSKE, Arthur S.J.. Pe. Antônio Sepp, SJ - O Gênio das Reduções Guaranis. São Leopoldo: Editora Unisinos, 2003. pp. 43-53

${ }^{28}$ BRAUMANN, op. cit., p. 16.
} 
pouco extenso, o trecho reproduzido serve para ilustrar as características apresentadas acima:

\begin{abstract}
Dos hombres de a caballo se apearon frente a él y lo interrogaron sobre su destino. Antonio, un inocente en esas lides, les informó detalladamente. Supieron entonces que se trataba de un caminante solitario, y que llevaba consigo una importante suma para el largo viaje. Le exigieron, pues, les entregase el dinero. Dedujo, con un inmediato golpe de intuición, que su 'misión' podía quedar concluida antes de su iniciación. Joven como era, sano y amigo de los ejercicios gimnásticos, no dudó: tomó por la chaqueta a uno de los ladrones y lo arrojó a un charco, cosa que repitió con el segundo antes que éste lograse desenvainar una tosca espada de su endurecida vaina. Y montando una de las cabalgaduras, y arriando la otra, prestamente se alejó del sitio peligroso. ${ }^{29}$
\end{abstract}

$\mathrm{Na}$ contracapa do livro, integrante da coleção "Misioneros que hicieron historia", explicita-se o desejo de que a vida e obra desses personagens tornem-se modelos para os leitores, "especialmente os mais jovens". O autor, em diversas passagens, afirma sua preocupação em adaptar os escritos de Sepp para um formato mais atual e em um estilo mais acessível. ${ }^{30}$ No entanto, o que fica evidente não é um resumo ou adaptação com linguagem mais moderna, mas a construção de toda uma cena, na qual o missionário, assim como os heróis dos filmes de gênero Western, utiliza suas habilidades para dominar bandidos, safando-se de apuros: "(...) tomó por la chaqueta a uno de los ladrones y lo arrojó a un charco. (...) Y montando una de las cabalgaduras, y arriando la otra, prestamente se alejó del sitio peligroso." ${ }^{31}$ Já que voltado especialmente para um público juvenil, a obra de Francisco Braumann busca atrair a simpatia do leitor para a narrativa do "nobre aventureiro jesuíta".

O jesuíta e antropólogo Bartomeu Melià (1932), por sua vez, estudou a fundo o lado indígena da relação de contato surgida no contexto missionário através de pesquisas principalmente nos campos da etnografia guarani, da etnohistória e da linguística. Neste último, analisa a questão da transformação da língua nativa, ao mesmo tempo em que a cultura se transformava com a inserção dessas populações em um esquema reducional. Para ele, a chave é a língua, vista como uma forma de se compreender a vida, a economia, as relações políticas e a sociedade. Busca traçar o

\footnotetext{
${ }^{29}$ BRAUMANN, Francisco. 3.000 Guaraníes y un Tirolés: Reducciones guaraníticas - Sepp Von Rainegg (1655-1733). Tradução: José Gallinger. Buenos Aires. Editorial Guadalupe. 1981. Título do original alemão: 3000 Indianer und ein Tiroler. Verlag St. Gabriel Steyer Verlag, 1977. p. 31.

${ }^{30}$ Ibidem, p. 80.

${ }^{31}$ Ibidem, p. 31.
} 
histórico destas transformações para tecer críticas sobre a situação da língua guarani no Paraguai atual (portanto, em sua condição de Estado-Nação). Defende uma postura de resistência dos guaranis, e não de aceitação total como é corrente na historiografia jesuítica, frente ao que seria uma invasão política, cultural e religiosa:

Los movimientos de resistencia activa contra la invasión y la dominación española por parte de los indios guaraní fueron mucho más numerosos que lo que deja entender la historiografía tradicional, que habla sobre todo de alianza hispano-guaraní y de mestizaje. Entre 1537 y 1616 los documentos históricos registran nada menos que veinticinco rebeliones de los guaraní contra la colonización española. ${ }^{32}$

Por outro lado, no que diz respeito especificamente ao contato de indígenas e missionários, o antropólogo jesuíta afirma que embora existissem conflitos, na maior parte das vezes este se dava de maneira pacífica, com a boa acolhida dos padres, que propunham um sistema de vida que parecia mais político e humano aos olhos dos índios:

(...) o mais freqüente, foi a boa acolhida que os padres tiveram. A fundação de povos foi feita de acordo com o gosto dos índios. A aprendizagem da língua guarani não podia ser feita sem um alto grau de convivência, embora os padres mantivessem suas habitações separadas e um estilo de vida que não era certamente o indígena. Os Guarani, por seu lado, participaram com entusiasmo da vida litúrgica proposta, que, em realidade, era muito solene e cheia de novidades. (...) Os jesuítas mostraram sentir-se muito bem com "seus" guarani, e os guarani com "seus" padres. ${ }^{33}$

Melià também atesta o valor de outros pesquisadores jesuítas e afirma que os lê como "colegas e amigos, não como hipócritas sonegadores da verdade (...)". ${ }^{34}$ Embora faça elogios constantes à atuação dos jesuítas junto aos povos nativos e, de certa forma, contribua para uma visão hegemônica de relação pacífica e harmoniosa entre eles, Bartomeu Melià traz inúmeras reflexões importantes para uma abordagem mais abrangente da história missioneira, que considera a atuação guarani seja na

32 MELIÀ, Bartomeu. El guarani conquistado y reduzido: ensayos de etnohistoria. Asunción: Universidad Católica, 1988, p. 33.

${ }^{33}$ MELIÀ, Bartomeu. As missões jesuíticas nos sete povos das missões: depoimento [18 de setembro, 2006]. São Leopoldo: Revista do Instituto Humanitas Unisinos. Entrevista concedida a IHU online. Disponível em: http://www.ihuonline.unisinos.br/index.php?option=com_content $\&$ view=article $\&$ id= $407 \&$ secao $=1$ 96. Acesso em: 04/03/2014.

${ }^{34}$ Ibidem. 
contestação ou aceitação de um projeto cristão colonizador.

Outro importante pesquisador jesuíta é o historiador Guillermo Furlong (18891974), cuja extensa produção alcança mais de oitenta obras, abordando os mais diversos temas do universo missioneiro, sendo todas de caráter apologético à Companhia de Jesus. Não podemos deixar de considerar louváveis seus esforços no levantamento de documentações em diversos arquivos espalhados pelo mundo, além do fato de ter sido um dos primeiros estudiosos a se propor elaborar uma História cultural das missões, em $1969 .{ }^{35}$ Embora possua problemas no tratamento e crítica das fontes utilizadas, a obra, divida em três tomos (Arte, Ciência e Sociedade), além de abarcar muitos aspectos que compõem o ambiente cultural surgido na região do rio da Prata, traz diversas informações sobre práticas musicais que nos serão úteis nesta pesquisa. Em uma das alusões ao aspecto musical no âmbito das missões, Furlong afirma:

(...) gracias a la singularísima aptitud de los indígenas para la música, ésta tuvo en América, desde California hasta Tierra del Fuego, una aceptación tan brillante como clamorosa, y una vez asentadas las primeras poblaciones fue la música uno de los elementos que más contribuyeron a su consolidación. En las treinta Reducciones de guaraníes la música, a la par de la vida espiritual, lo fue todo. ${ }^{36}$

Além desta obra, o historiador inaciano trata das atividades musicais nos povoamentos jesuítico-guaranis em outros trabalhos ${ }^{37}$ que, embora de caráter bastante laudatório e com alguns problemas na utilização de termos técnicos referentes à música ou instrumentos musicais, nos apresentam panoramas gerais. Ainda mais importante para nós é o livro que escreveu sobre a vida e atuação do padre Antônio Sepp, ${ }^{38}$ que utilizaremos como referência nesta pesquisa. Embora enalteça constantemente as qualidades do missionário tirolês e defenda-o em todos os momentos, Furlong, diferente de outros autores que escreveram sobre este personagem, não omite informações que poderiam contradizer a imagem que busca construir.

\footnotetext{
35 FURLONG, Guillermo S.J. Historia social y cultural del Rio de la Plata: 1536-1810. Buenos Aires: Tipográfica Editora Argentina, 1969.

${ }^{36}$ Ibidem, p. 167.

${ }^{37}$ Cf. FURLONG, Guillermo S.J. Músicos argentinos durante la dominación hispánica. Buenos Aires: Huarpes, 1944.

38 FURLONG, Guillermo S.J. Antonio Sepp y su "gobierno temporal" (1732). Buenos Aires: Ediciones Theoria, 1962.
} 


\subsubsection{Simpatizantes}

Robert Southey (1774-1843), historiador inglês, protestante, que escreveu uma História Geral do Brasil, ${ }^{39}$ publicada entre 1810 e 1819, abrangendo todo o período colonial, é um exemplo de autor que pode ser considerado simpático à Companhia de Jesus, pois vê com apreço o trabalho realizado pelos jesuítas. Apoiando-se fartamente em documentos dos séculos XVI e XVII (sobretudo referentes a viajantes e missionários), descreve, numa perspectiva ainda etnocêntrica, o indígena e seus costumes, muitos dos quais coloca como "grandes e numerosos obstáculos" à empresa jesuítica. Em diversos momentos de sua obra, relata as precariedades em que viviam os inacianos, empenhados não só na salvação espiritual, mas também na salvação física dos indígenas, destacando os méritos do trabalho de Anchieta e Nóbrega. Ao discorrer sobre a expulsão dos missionários do território brasileiro, afirma que foram expulsas "as únicas pessoas que desinteressadamente promoveriam o adiantamento e a felicidade dos índios, as únicas que pelo amor de Deus se voltariam de alma e coração ao serviço do próximo." 40

O historiador Aurélio Porto (1879-1945) representa uma linha de pesquisadores comprometidos com a elaboração de uma história oficial, estabelecendo relações entre a experiência missioneira e a identidade cultural de uma região, no caso, o Rio Grande do Sul. Sobre o contexto histórico em que foi publicada sua obra História das Missões Orientais do Uruguai, ${ }^{41}$ Focking afirma: "A necessidade de uma 'história oficial das missões' surge no momento de institucionalização de políticas federais de preservação do Patrimônio Histórico no Brasil, no contexto do Estado Novo." ${ }^{42}$ Dessa forma, Aurélio Porto busca, através de seu texto, apresentar a contribuição da experiência missioneira para a história da arte brasileira e para a formação histórica do estado gaúcho.

Porto avança em comparação à produção historiográfica anterior por mostrar-

\footnotetext{
${ }^{39}$ SOUTHEY, Robert. História do Brasil. São Paulo, Melhoramentos. 1977.

${ }^{40}$ Ibidem, vol. 3, p. 294.

${ }^{41}$ PORTO, Aurélio. História das Missões Orientais do Uruguai. Rio de Janeiro: Imprensa Nacional, 1943. Disponível em: http://ufdc.ufl.edu/AA00011461/00001. Acesso em: 05/03/2014.

${ }^{42}$ FOCKING, G. F. A História das Missões Orientais do Uruguai e a memória nacional. In: XXVII Simpósio Nacional de História - Conhecimento histórico e diálogo social. Natal, 22 a 26 de julho de 2013. 20 p. 6.6 Disponível em: http://snh2013.anpuh.org/resources/anais/27/1364743174_ARQUIVO_Gabriel_Focking_Missoese memorianacional.pdf. Acesso em: 05/03/2014.
} 
se preocupado em referenciar as informações apresentadas. Baseia-se em ampla documentação retirada da Coleção De Angelis, ${ }^{43}$ da qual nossa pesquisa também se utiliza, na abordagem da atuação dos jesuítas na Província do Paraguai, denominandoa "civilização jesuítica-colonial". No entanto, persiste uma visão dos jesuítas como civilizadores dos povos indígenas "bárbaros, primitivos e pagãos".

Francisco Curt Lange (1903-1997), por sua vez, é referência não só para esta pesquisa como para todas aquelas que se debruçam sobre a música colonial iberoamericana. Mesmo tendo trabalhado em grande parte com a região das Minas Gerais de fins do século XVIII, realizando a primeira abordagem aprofundada sobre a atividade musical colonial e suas implicações em aspectos administrativos e sociais, ou seja, dando o devido valor ao contexto em que esta música se inseria, e tornandose célebre por seus exaustivos trabalhos de compilação documental, o musicólogo alemão radicado no Uruguai também se voltou para as evidências de músicas praticadas nas missões. Nas décadas de 1950 e 1960, Lange levou a cabo uma investigação sistemática em torno das atividades musicais da Companhia de Jesus na região do Rio da Prata, Gran Chaco, junto aos Índios Chiquitos e Moxos, inventariando os bens musicais presentes em algumas missões na época da expulsão dos jesuítas, ${ }^{44}$ assim como importantes mapas dos domínios de atuação da ordem. O musicólogo mostra simpatia com a atuação dos missionários, tecendo elogios em diversos momentos: "Aquellos que están familiarizados con sus incalculables sacrificios, abnegación y amor paternal hacia los indios, comprenderán su grandeza." ${ }^{45}$ No entanto, esta postura não diminui a relevância de seu trabalho.

A pequena monografia do organista Jorge Hirt Preiss também traz contribuições valiosas para esta pesquisa. A publicação de seu livro, A Música nas Missões Jesuíticas nos Séculos XVII e XVIII, ${ }^{46}$ assim como o de Aurélio Porto, teve

43 Os sete volumes que compõem os Manuscritos da coleção de Angelis foram publicados pela Biblioteca Nacional em diferentes datas, com introdução, notas e glossário de Jaime Cortesão. Todos eles encontram-se hoje em formato digital, no site da Biblioteca Nacional. Disponível em: http://bndigital.bn.br/projetos/angelis/spa/exposicion2.html. Acesso em: 05/03/2014.

${ }^{44}$ LANGE, Francisco Curt. El Extrañamiento de la Compañia de Jesús del Río de la Plata (1767). Los bienes musicales y la constancia de su existencia a través de los inventarios practicados - $1^{\mathrm{a}}$ Parte. In: Revista Musical Chilena. $165 \quad$ (XL): 4-58, 1986. Disponível em: www.revistamusicalchilena.uchile.cl/index.php/RMCH/article/download/13286/13561+\&cd=2\&hl $=$ pt-BR\&ct=clnk\&gl=br. Acesso em: 05/03/2014. A segunda parte, presente no número $176(\mathrm{XLV})$ da Revista Musical Chilena: 42-56, é de 1991 e está disponível em: www.revistamusicalchilena.uchile.cl/index.php/RMCH/article/viewFile/13909/14196+\&cd=7\&hl= pt-BR\&ct=clnk\&gl=br. Acesso em: 05/03/2014.

45 Ibidem, p. 5.

${ }^{46}$ PREISS, Jorge Hirt. A música nas missões jesuíticas nos séculos XVII e XVIII. Porto Alegre: Martins Livreiro Editor, 1988. 
significativas influências do contexto em que o autor estava inserido. Um ano antes da publicação da obra, Preiss, compositor da trilha sonora do Espetáculo de Luz e Som de São Miguel, ${ }^{47}$ recebeu o convite do Instituto Gaúcho de Tradição e Folclore para apresentar uma palestra, cujo conteúdo era um resumo do que se tornaria seu livro, no II $^{\mathrm{o}}$ Simpósio de Estudos Missioneiros de São Luiz Gonzaga, organizado em comemoração do tricentenário da cidade-redução, que ocorreria em 1988.

O autor afirma, na introdução de sua obra, que ao compor o espetáculo para São Miguel, notou a ausência de estudos sistemáticos sobre a música nas reduções, o que o levou a dedicar-se ao assunto. Após a apresentação de sua palestra em 1987, recebeu o apoio e incentivo de amigos do Instituto Histórico e Geográfico de São Luiz Gonzaga, em especial de Dante de Laytano, então Presidente da Academia SulRio Grandense de Letras, para que escrevesse um livro sobre o tema. No entanto, diferente do trabalho de Aurélio Porto, Jorge Hirt Preiss não se ocupa em tecer relações entre a cultura missioneira e a gaúcha, o que se restringe apenas ao Prefácio, escrito por Laytano. Nesta pequena obra, o musicólogo se atém exclusivamente ao fenômeno cultural representado pelas práticas musicais nas Missões.

Preiss apresenta um panorama da música europeia no período, salientando as profundas transformações pelas quais passava e mostrando, com ricas ilustrações, os diferentes instrumentos existentes lá e que foram trazidos para a América. Tais imagens são complementadas pela existência de um glossário de instrumentos musicais, presente ao final do livro. Não esquece, porém, de refletir sobre a música guarani e seus papéis na estrutura das sociedades nativas. Ancorado principalmente em cartas de missionários e crônicas de viajantes, o autor analisa o ensino da música ministrado pelos jesuítas aos indígenas, cuja vocação para ela é destacada, e relaciona missionários que contribuíram para esta tarefa desde o início do estabelecimento de reduções jesuíticas em terras paraguaias até a expulsão da Companhia do continente. Aborda ainda a fabricação de instrumentos em oficinas nas reduções e algumas das composições que acredita terem circulado no universo missioneiro.

Mesmo analisando quase que exclusivamente aspectos musicais, Preiss deixa

47 “Criado em 1978, pelo Governo do RS, trata-se de uma narrativa da história das Missões JesuiticoGuarani contada através de efeitos de som e luzes. Narra em 48 minutos o nascimento, desenvolvimento e o fim da civilização criada no Rio Grande do Sul por padres jesuítas e índios guarani. Texto e roteiro de Henrique Grazziotin Gazzana e as vozes de Lima Duarte, Paulo Gracindo, Armando Bógus, Fernanda Montenegro, Maria Fernanda, Juca de Oliveira e Rolando Boldrin." Texto tirado do site da Prefeitura de São Miguel das Missões. Disponível em: http://www.saomiguel.rs.gov.br/portal1/municipio/ponto_turistico.asp?iIdMun=100143378. Acesso em: 05/03/2014. 
transparecer certa simpatia, se não pela Companhia de Jesus em si, pela prática musical levada a cabo pelos jesuítas na relação com os povos nativos. Dedica um capítulo de seu livro a Antônio Sepp, tecendo elogios ao missionário:

Esse padre de personalidade fascinante, de uma cultura geral invulgar para a sua época, de uma sensibilidade artística tamanha que deu novo impulso e novos rumos à música nas Missões, foi instruído nessa arte desde criança. ${ }^{48}$

Com relação ao resgate das músicas executadas nas reduções jesuíticas da América do Sul, temos que salientar os esforços do maestro e investigador musical Luis Szarán. Através de pesquisas em arquivos, transcrições, reconstruções e edições de repertório musical, com ênfase no compositor jesuíta Domenico Zipolli (16881726), o autor busca possibilitar o estudo e a revalorização da música missioneira. ${ }^{49}$

Szarán possui, inclusive, um premiado projeto de integração social e comunitária por via da música, chamado Sonidos de la Tierra. ${ }^{50}$ Salvo os benefícios diretos surgidos com esta iniciativa, como a redução da violência entre jovens e o fomento cultural, tais ações são criticadas por outros estudiosos que consideram suas orquestras juvenis uma perpetuação do racismo e da experiência opressiva dos missionários, fazendo com que, em festivais contemporâneos de música missioneira, turistas brancos, assim como os viajantes de outrora, se admirem com a capacidade daqueles jovens indígenas em executar músicas europeias. Pode-se ter um exemplo do caráter civilizador desta prática pela frase considerada o lema do projeto de Szarán, presente em seu site oficial: “el joven que durante el día interpreta a Mozart por la noche no romperá vidrieras." 51

Enquanto seus estudos no campo da Musicologia e no resgate de partituras trazem significativas contribuições, seus trabalhos investigativos e biográficos, como

\footnotetext{
${ }^{48}$ PREISS, Jorge Hirt. A música nas missões jesuíticas nos séculos XVII e XVIII. Porto Alegre: Martins Livreiro Editor, 1988. p. 29.

49 A lista completa de edições de repertório musical organizado e revisado por Luis Szarán está disponível em seu website: http://www.luisszaran.org/Libros.php?lang=es. Acesso em: 03/02/2014.

${ }^{50}$ Para mais, acessar: http://www.sonidosdelatierra.org.py/. Acesso em: 03/02/2014.

${ }^{51}$ Para mais sobre as discussões acerca do surgimento de orquestras com crianças indígenas para execução de repertórios clássicos e missioneiros, conferir os trabalhos de Guillermo Wilde e Leonardo Waisman. Em especial: WAISMAN, Leonardo. The Singing Demons Of San Ignacio: Musical Interfaces Between Jesuits and Indians. In: Colloquim on the Department of Music Columbia University. New York, 15/02/2013. Disponível em: https://www.academia.edu/3815396/The_Singing_Demons_of_San_Ignacio_Musical_Interfaces_b etween_Jesuits_and_Indians. Acesso em: 13/08/2013.
} 
o livro sobre a vida de Domenico Zipolli, ${ }^{52}$ deixam a desejar. Músico de formação, ele acaba pecando pela falta de problematizações e pelo caráter de História factual, com certo tom apologético aos jesuítas. Em muitos trechos, apenas reproduz a opinião presente em obras de historiadores da Companhia.

\subsection{Os contrários}

A segunda categoria de pesquisas que abordaremos neste balanço diz respeito aos trabalhos com viés "anti-jesuíta". Em geral são escritos de historiadores, antropólogos e sociólogos, que apresentam algum nível de crítica documental, não vinculada institucionalmente à produção historiográfica e, ainda menos, à construção da memória oficial da Ordem dos Jesuítas. Por não estarem preocupados em resguardar a imagem dos personagens estudados ou em legitimar ações pelos contextos em que se inserem, na maior parte das vezes apresentam críticas à atuação da Companhia de Jesus junto aos indígenas paraguaios. Tais estudos, utilizando fontes jesuíticas e também estudos de outras áreas de conhecimento, contribuíram muito para o avanço das pesquisas sobre o universo missioneiro ao apresentarem novas visões, hipóteses e, principalmente, questionamentos. Deve-se, porém, estar atento ao fato de que muitos autores enquadrados nesta tipologia por vezes comprometem suas análises na busca pela construção de uma imagem necessariamente pessimista da atuação da Companhia de Jesus de forma geral, caindo na mesma armadilha dos apologéticos, mas por motivos diametralmente opostos.

Como primeiro representante desse grupo, apresentamos o historiador e ensaísta paraguaio Efraím Cardozo (1877-1951), que contribui para este debate através de seus inúmeros e sistemáticos trabalhos acerca da história do Paraguai (aqui entendido como Estado-Nação). Sua intensa atuação política marca profundamente sua obra, pois busca através da investigação histórica, baseada em farta documentação, defender os interesses de seu país, como é o caso de seus estudos sobre a região do Chaco, que na época da publicação de sua tese de doutoramento em História (1932) era reivindicada pela Bolívia.

Cardozo estudou praticamente todos os períodos da história de seu país, desde a conquista espanhola até a contemporaneidade, tendo publicado mais de uma dezena

52 SZARÁN, Luis. Domenico Zipolli (1688-1726): Una vida, un enigma. Nurenberg: Fundación Paracuaria - Missionsprokur S.J., 2005. 
de livros, além de artigos e ensaios. Dentre estes, destacamos sua impressionante Historiografía Paraguaya. ${ }^{53}$ No primeiro volume (o segundo não chegou a ser publicado), elabora uma das mais detalhadas sistematizações de autores, obras e fontes referentes ao estudo das populações nativas e da atuação tanto da Coroa espanhola quanto de religiosos, não os poupando de críticas, em territórios que hoje correspondem aos da nação paraguaia. O quinto capítulo (quinta parte) de sua obra é dedicada exclusivamente às missões jesuíticas paraguaias e apresenta importantes referências a documentos e bibliografia sobre o Padre Sepp.

Efraím Cardozo expõe, inclusive, informações que muitas vezes foram omitidas de obras de pesquisadores jesuítas aos quais tivemos acesso, como no caso de quando Antonio Sepp S.J. foi "vergonzosamente desterrado" ${ }^{54}$ de sua redução por certas acusações feitas pelos indígenas. Ao debruçar-se sobre as correspondências de Sepp, Cardozo censura seus comentaristas anteriores, em sua maioria intelectuais ligados à Ordem, pela falta de olhar crítico no tratamento das fontes. Aliás, uma de suas maiores qualidades reside justamente na preocupação em referenciar as informações dadas, apontando fontes e documentos pesquisados.

Também não podemos deixar de fora a abordagem de Luiz Felipe Baêta Neves, em Os combates dos soldados de Cristo na Terra dos Papagaios: Colonialismo e Repressão Cultural, ${ }^{55}$ de 1978. O antropólogo tece duras críticas ao falar da permanência e dominância de uma determinada ideologia jesuítica relativa ao indígena que, segundo ele, se faria presente até os dias em que sua obra foi publicada, permeando políticas públicas e práticas institucionais:

A posição jesuíta se beneficiou de um silêncio espantoso que se impôs a dezenas de gerações (...). Silêncio que se consubstancia em uma ausência maciça, quase absoluta, de estudos críticos sobre tal posição. Mas tal silêncio é absolutamente enganoso; na verdade não há silêncio - o que há é a repetição da fala (e da ação) dos religiosos. ${ }^{56}$

Baêta Neves apresenta seu texto como uma tentativa de demolição do que considera como "fantasmas ideológicos que insistem em vagar pela cena brasileira."

53 CARDOZO, Efraím. Historiografía Paraguaya. Tomo I. México: Instituto Panamericano de Geografia e Historia, 1959.

${ }^{54}$ Ibidem, p. 264.

${ }^{55}$ NEVES, L. F. B. O Combate dos Soldados de Cristo na Terra dos Papagaios: Colonialismo e Repressão Cultural. Rio de Janeiro, Forense - Universitária, 1978.

${ }^{56}$ Ibidem, pp. 16-7. 
Sua monografia está inserida em um cenário de produção historiográfica que tem como característica fundamental investigar as formas de domínio colonial colocando as práticas culturais no centro de sua reflexão. Inova na temática ao destacar a atuação dos jesuítas sob a ótica das formas de preocupações cotidianas, ou seja, as formas não institucionais de exercício de poder. Ao privilegiar o estudo da imposição de valores da cultura do europeu-cristão sobre as sociedades ameríndias, sua abordagem está ligada à análise antropológica do processo do contato. Dessa forma, sua pesquisa expõe um discurso religioso substituído por uma prática, fruto da experiência. Em sua problematização, é notório o esforço para mostrar o jesuíta como indivíduo, passível de críticas por suas ações junto aos indígenas. Ainda que novos estudos tenham surgido para ajudar a "demolir fantasmas" e "romper o silêncio", a obra de Luiz Felipe Baêta Neves ainda pode ser considerada como referência.

Outro nome a fazer coro aos críticos da Ordem Inaciana é o do sociólogo Florestan Fernandes (1920-1995) que, ao pensar a relação das sociedades indígenas com o mundo colonial, vê os jesuítas como autênticos agentes da colonização. Ele afirma que:

A atuação aparentemente construtiva dos jesuítas convergiu, no entanto, para resultados negativos, pois ela era dirigida no sentido de fazer com que as tribos submetidas se acomodassem à ordem social ditada pelo invasor. ${ }^{57}$

Para o autor, o indígena torna-se elemento chave de uma ideologia dominante no mundo colonial, neste caso, lusitano, acabando por instaurar polarizações com os diversos elementos colonizadores. Em primeiro lugar, com o colono que o submetia à escravidão; em segundo lugar, com o administrador ou agente da Coroa que organizava a exploração agrícola; e por último, com o clero, notadamente os jesuítas, que, mesmo contrariando muitos dos interesses dos colonos, igualmente geravam profundas alterações na cultura nativa e desarranjo da "sociedade tribal".

Considerando desigual a interação entre sociedades marcadas por estruturas diversas, Florestan Fernandes inaugura um modo de pensar a relação das sociedades indígenas com o mundo colonial. Admite o processo desagregador levado a cabo

57 FERNANDES, Florestan. Antecedentes indígenas: organização social das tribos tupis. In: HOLANDA, S. B.; CAMPOS, P. M. (org.). Historia Geral da Civilização Brasileira - A Época Colonial. Do Descobrimento a Expansão Territorial. Rio de Janeiro. Bertrand Brasil, 1989. v.1 t.1 p. 83. Para mais sobre as diferentes interpretações sobre a atuação dos jesuítas no Novo Mundo Cf. BRANDAO, H. H. N. Estudos sobre o discurso. Tese (Livre Docência). FFLCH-USP, São Paulo, 2001. 
pelos jesuítas nas "sociedades tribais" e, acima de tudo, situa este mundo na perspectiva sócio-histórica, compreendendo a importância das contradições sociais surgidas entre brancos e índios para a explicação da formação da sociedade brasileira.

\subsection{Crítica Histórica}

A impossibilidade de enquadrar a totalidade dos trabalhos dentro da dicotomia apologistas e "contrários" à atuação da Ordem deve-se a diversos estudos em que a crítica está ligada a um maior rigor documental e metodológico, o que não necessariamente implica em um enaltecimento, contestação ou detração dos jesuítas. Por este motivo, optamos em criar uma terceira categoria, a de crítica histórica, que envolve pesquisadores preocupados com a análise aprofundada de aspectos da atuação missionária e em geral com trabalhos mais específicos do que panorâmicos, com recortes mais definidos e focando em determinadas áreas científicas na busca pela compreensão do contexto. Destaque para historiadores e musicólogos.

Darcy Ribeiro (1922-1997), ao abordar a experiência dos padres da Companhia de Jesus junto às reduções do Rio da Prata e seus afluentes, insere-a no contexto colonial espanhol como um espaço de exceção. Um sistema cooperativo, livre da encomienda, já consolidada em territórios coloniais espanhóis e através da qual os colonizadores recebiam da Coroa a permissão de obrigar os índios a trabalhar, como forma de indenização pelos serviços de civilização e cristianização recebidos. Em seu livro As Américas e a Civilização, o antropólogo, ao abordar os missionários jesuítas, afirma:

Suas missões paraguaias constituem a tentativa mais bem sucedida da Igreja Católica para cristianizar e assegurar refúgio às populações indígenas, ameaçadas de absorção ou escravização pelos diversos núcleos de descendentes de povoadores europeus para organizá-los em novas bases, capazes de garantir sua subsistência e seu progresso. ${ }^{58}$

Outro trabalho a ser destacado é o do sociólogo Maxime Haubert, Índios e Jesuítas no Tempo das Missões. ${ }^{59} \mathrm{O}$ autor parte de uma perspectiva em que os jesuítas

\footnotetext{
${ }^{58}$ RIBEIRO, Darcy. As Américas e a civilização: processo de formação e causas do desenvolvimento desigual dos povos americanos. $2^{\mathrm{a}}$ edição. Petrópolis: Vozes, 1977, p. 41.

${ }^{59}$ HAUBERT, Máxime. Índios e Jesuítas no Tempo das Missões. Prefácio de Jacques Soustelle; tradução de Marina Appenzeller. São Paulo, Companhia das Letras: Círculo do Livro, 1990. Título
} 
não são os únicos agentes das relações de contato, dando espaço para que o indígena apareça como agente histórico e porta-voz dessas relações. O autor critica as pesquisas tradicionais que tratam os guaranis como "uma raça perdida e degenerada, que só pode entrever o Bem por intermédio da graça divina e da santidade inabalável de todos os jesuítas." 60

Aproximando-se de Baêta Neves, analisa a conquista através das práticas. Desse modo, a visão idealizada, marca de uma historiografia tradicional da Companhia de Jesus, desaparece para dar lugar à análise do choque surgido no confronto de sistemas sociais opostos. Ressalta a constituição de uma cultura e sociedade que se caracterizaram por formas híbridas, tendo no jesuíta o negociador desse novo sistema, à medida que são os condutores da tradução dos signos e códigos do mundo cristão para o ameríndio.

Haubert mostra maior amplitude na escolha das fontes, baseando-se nas correspondências e relatórios dos missionários, assim como nas recomendações e ordens dos superiores da Companhia de Jesus, além de obras antropológicas. Sua narrativa, no entanto, algumas vezes carrega na imaginação, apresentando, como descrito na orelha de seu livro, "um resultado literário mais próximo dos romances de aventura do que das teses acadêmicas."

Neste ponto, vale citarmos o trabalho de doutoramento em Teologia de Carlos José Griebeler ${ }^{61}$, que analisa, a partir das cartas de Antônio Sepp, o que acredita ser a elaboração de um imaginário missionário jesuíta que legitimaria ações junto aos indígenas. Para o autor, os escritos do missionário constituem uma fonte de pesquisa relevante, pois revelam a complexidade das relações surgidas no contato de jesuítas e ameríndios, assim como o processo de instituição de significados que as complementa. O discurso estruturado por Sepp manifestaria dimensões constitutivas das práticas missionárias levadas a cabo pelo padre e do imaginário que lhes é inerente.

Griebeler preocupa-se em demonstrar como as opções ideológicas do jesuíta, herdeiras de sua formação inaciana, europeia e ocidental, podem ser evidenciadas no

original: La vie quotidienne des indiens et jésuites du Paraguay au temps de missions. Librairie Hachette, 1967.

${ }^{60}$ Ibidem, p. 23.

61 GRIEBELER, Carlos José. A construção do imaginário missionário na correspondência epistolar de Antônio Sepp. 2008. 199f. Tese de Doutorado em Teologia. EST/IEPG, São Leopoldo. 2008. Disponível em: http://tede.est.edu.br/tede/tde_busca/arquivo.php?codArquivo=80. Acesso em: 15/04/2014. 
desenvolvimento de suas elaborações discursivas. Sua intenção é captar como o missionário percebia e apreciava a realidade com a qual estava em contato e como sua percepção estava, obviamente, carregada de juízos preconceituosos em relação aos indígenas. Trabalhando com o conceito de alteridade, Carlos José Griebeler busca demonstrar que as formulações do jesuíta tenderiam a ressaltar e estigmatizar aspectos característicos da cultura ameríndia que não fossem condizentes com a implementação da nova vida reducional. Para o teólogo, o entendimento, por parte de Sepp, de que na missão encontrava-se ao lado de "índios irracionais", e tendo em mente seu dever apostólico de trazer os "pagãos" à fé católica, justificaria a necessidade de sua intervenção, de caráter tutelar.

A pesquisa de Griebeler, embora não traga grandes novidades ao debate, nos é útil ao analisar os escritos de Antônio Sepp por outro viés, tendo outras preocupações e questionamentos e não levando em conta apenas sua atuação como músico ou fundador e administrador de reduções. Além disso, não se restringe a um caráter biográfico.

Atuando em uma área de conhecimento diferente de Carlos José Griebeler, mas também buscando entender melhor aspectos do universo missioneiro, o músico, artista plástico e investigador de História da Arte, Horacio Bollini, parece seguir os passos de Jorge Hirt Preiss e apresenta dois estudos aprofundados sobre variadas manifestações artísticas nas missões, as quais o autor caracteriza como um fenômeno sócio-cultural imenso. Seu Arte en las Misiones Jesuíticas ${ }^{62}$ apresenta um resumo da história da Companhia de Jesus e de sua atuação em terras paraguaias para, a partir daí, descrever amplamente as práticas artísticas nas reduções, em especial as artes visuais e a música. Preocupa-se também em tentar entender quais eram os povos reduzidos e quais eram os elementos centrais de sua cultural e universo cosmológico.

Horacio Bollini busca mostrar como as práticas culturais formavam, no espaço missioneiro, um mosaico cujo poderoso influxo simbólico guiava os povoamentos. Descreve como o trabalho nas oficinas deu luz a interpretações singulares da arte europeia através de sincretismos culturais, convertendo o território compreendido pela Província Jesuítica do Paraguai no mais ativo centro de trabalhos artísticos da América do Sul. Dedica todo um capítulo à questão da música no contexto reducional e muitas páginas para a atuação do Padre Antônio Sepp, que considera como "una de

${ }^{62}$ BOLLINI, Horacio. Arte en las Misiones Jesuíticas: Los espejos del Mundo Jesuítico-Guaraní. Buenos Aires: Corregidor, 2007. 
las personalidades más importantes que pasaron por las reducciones guaraníes: sus escritos se han vuelto espejos donde los perdidos escenarios de las misiones ensayan otra vez el sortilegio de la música." ${ }^{63}$

Em seu outro livro, Misiones Jesuíticas - visión artística y patrimonial, ${ }^{64} \mathrm{o}$ enfoque passa a ser urbanístico e Bollini busca compreender as relações entre o espaço das reduções e o universo simbólico que os jesuítas tentavam criar. Analisa as construções, as igrejas e a concepção urbana repleta de alegorias cristãs, que tinham por objetivo influenciar o cotidiano e o imaginário de seus habitantes. Bollini realiza um sistemático estudo de elementos arquitetônicos e artísticos de cada uma das trinta reduções jesuítico-guaranis. Embora suas obras tenham caráter de ensaios, pecando pela falta de referências, podem ser consideradas como muito relevantes no que diz respeito à análise de aspectos culturais, em especial à música das missões.

Devemos mencionar também os instigantes trabalhos do musicólogo Leonardo Waisman, que há mais de trinta anos estuda práticas musicais no espaço colonial americano. Vários de seus artigos abordam a problemática do barroco missioneiro como termo para designar a música que se executava nas missões nos séculos XVII e XVIII. Waisman problematiza a corrente tradicional de pensamento entre músicos, críticos e musicólogos que tenta representar a música ibero-americana do período colonial como um produto original e uma manifestação das singularidades deste continente, principalmente por duas vias inter-relacionais: o excesso e a mestiçagem. O musicólogo segue uma linha de raciocínio que, em primeiro lugar, busca entender o que caracterizamos como barroco; em seguida, busca compreender como este conceito se ajusta, ou não, à música praticada nas missões. Por fim, conclui que:

Llamar de "barroco misional" a la música de las reducciones jesuíticas, puede, entonces, representar algún grado de verdad. De alguna manera, y hechas las debidas reservas, puede ayudarnos a colocar a este objeto dentro de nuestro mapa cognitivo. Pero, en grado mucho mayor, significa colaborar con un slogan de las industrias culturales, vacío de contenido como todos los eslóganes. ${ }^{65}$

Em outro artigo abordando compositores coloniais, o musicólogo critica a

${ }^{63}$ BOLLINI, Horacio. Arte en las Misiones Jesuíticas: Los espejos del Mundo Jesuítico-Guaraní. Buenos Aires: Corregidor, 2007. p. 204.

${ }^{64}$ BOLLINI, Horacio. Misiones Jesuíticas - visión artística y patrimonial: Voces y emblemas en las reducciones jesuítico-guaraníes: 1609-1768. Buenos Aires: Corregidor, 2009.

${ }^{65}$ WAISMAN, Leonardo. Musica Del Barroco Misional: ¿Un Concepto o un Slogan?. In: WILDE, Guillermo (org.). Saberes de la Conversión - Jesuítas, Indígenas e Impérios Coloniales en las Fronteras de la Cristiandad. Buenos Aires: Editora Sb, 2011. p. 344. 
valorização exagerada das contribuições indígenas na música executada nas missões, afirmando que, na maior parte das vezes, o que lemos nas partituras é a voz dos dominadores, os missionários, sendo mínimos os resquícios que nos permitem atestar alguma característica impressa pelos "subordinados", os indígenas. ${ }^{66}$ A contribuição de Leonardo Waisman é valiosa na medida em que traz inúmeros questionamentos sobre temas e conceitos cristalizados na historiografia tradicional. Ajuda-nos a pensar quem eram os atores envolvidos na prática musical, em que espaços e circunstâncias essa prática se dava e como ela interferia na sociedade missioneira ao mesmo tempo em que recebia influências decorrentes de sua estruturação. Além disso, traz novas perspectivas para as contribuições entre Musicologia e História que nos serão úteis neste trabalho.

Evocamos novamente a importância dos estudos de Guillermo Wilde. Sua produção contribui muito para o avanço dos estudos sobre a música nas missões paraguaias, ao estudá-la em seus diversos papéis no ambiente reducional. Aborda tanto o controle que os missionários tentavam fixar através de seu uso, quanto a apropriação pelos indígenas como forma de resistência e afirmação de identidade. Em seus diversos artigos e obras publicadas, Wilde defende um olhar antropológico sobre as fontes históricas e incentiva a necessidade de maior interdisciplinaridade nos estudos missioneiros.

Para ele, a música missioneira se caracterizava por ser híbrida, múltipla e fluida, suscetível à incorporação de elementos locais e, portanto, sumamente diversa. $\mathrm{O}$ autor nega a passividade dos indígenas, afirmada e reafirmada por seus antecessores, no que atenta para a produção musical. Reflete inclusive sobre as adaptações feitas pelos missionários nas partituras vindas da Europa, copiadas e executadas nas missões. Ao contrário das correspondências dos jesuítas e das crônicas de viajantes, que apontam a adaptação/simplificação das músicas como necessária para que os indígenas pudessem executá-las, em decorrência de uma suposta falta de capacidade, Wilde afirma que tais modificações poderiam se tratar, porém, de uma tentativa dos missionários de se aproximarem dos padrões de produção estética indígenas, já que guaranis e chiquitos, por exemplo, não costumavam ornamentar suas melodias.

Ele aponta também para o perigo de se cair em anacronismos na utilização de

66 WAISMAN, Leonardo. La contribuición a la música misional em mojos (Bolívia). Revista Memoria Americana: cuadernos de etnohistoria. n.12. Buenos Aires, 2004. 
conceitos e valores ocidentais, como "autoria de composições", durante a análise da música missioneira, repleta de significados religiosos e cerimoniais. Tais conceitos, como afirma o autor, são resultantes de uma autonomização do campo das artes que se deu posteriormente ao período em questão. Uma de suas obras, Saberes de la conversión: Jesuitas, indígenas e imperios coloniales en las fronteras de la cristiandad, ${ }^{67}$ compila artigos de especialistas em música, artes, arquitetura colonial entre outros aspectos, sendo de fundamental importância para aqueles que buscam se aprofundar na matéria.

Fica evidente, até aqui, a predominância de trabalhos em língua espanhola. $\mathrm{Na}$ historiografia em língua portuguesa, não são muitos os estudos que problematizam o espaço ocupado pela música e a função temporal e espiritual que sua prática adquiriu junto a indígenas e missionários nas reduções jesuíticas dos rios da Prata, Paraná e Paraguai. Mesmo sendo poucos, não pudemos nos furtar de pesquisas em português que trazem aspectos relevantes ao debate que nos propusemos realizar. Em sua maioria, abordam a música no contexto colonial da América portuguesa e têm a região das Minas Gerais como foco. Alguns deles, porém, nos trazem um panorama geral ou focam a região que aqui nos interessa.

Um musicólogo brasileiro com extensa produção científica é Paulo Castagna, que traz importantes contribuições para este trabalho ao traçar um histórico detalhado das prescrições tridentinas quanto ao uso do estilo antigo e moderno na música religiosa católica. Ele caracteriza estes estilos, demonstrando suas diferenças, as ocasiões em que eram utilizados e o contexto em que tais alterações normativas foram surgindo, tanto na Europa quanto na América. ${ }^{68}$ Como se atribui ao padre Antônio Sepp o crédito pela transmissão do estilo moderno em terras paraguaias, ${ }^{69}$ os estudos de Castagna ajudam a compreender as funções e características da música religiosa católica latino-americana de fins do século XVII e início do XVIII. De forma mais específica, em outro trabalho, o musicólogo faz um interessante cotejo entre as edições das cartas de Sepp em três línguas diferentes, atentando para as diferenças nas

67 WILDE, Guillermo. (org. e ed.) Saberes de la Conversión - Jesuítas, Indígenas e Imperios Coloniales en las Fronteras de la Cristandad. Buenos Aires: Editorial SB, 2011.

68 "Enquanto o estilo antigo baseava-se em normas composicionais derivadas da música romana contra-reformista, o estilo moderno utilizava inúmeras técnicas composicionais, sobretudo italianas, derivadas da ópera e da música instrumental.” Cf. CASTAGNA, P. A. Estilo antigo e estilo moderno na música antiga latino-americana. In: Apostila do curso História da Música Brasileira. São Paulo, Instituto de Artes da Unesp, 2004. p. 2. Disponível em: http://www.ia.unesp.br/Home/AreadoAluno/HMB_2004_apostila05.pdf. Acesso em: 04/03/2014.

${ }^{69}$ Todos os musicólogos que incluímos no grupo de Crítica Histórica parecem concordar neste ponto. 
traduções e destacando que realizou adaptações para minimizar erros presentes no texto (traduções erradas de termos referentes às notações musicais e instrumentos). ${ }^{70}$

Ao discorrer sobre a música missioneira, Paulo Castagna faz coro com Leonardo Waisman ao afirmar que:

Uma das questões mais complexas no estudo dessa música é a sua caracterização estilística. Os estilos utilizados na música religiosa latino-americana e mesmo europeia têm sido objeto de vários trabalhos, mas ainda são frequentes as classificações baseadas na nomenclatura utilizada em compêndios de história da música européia, essencialmente aplicada à música profana: renascimento, barroco, classicismo, etc. ${ }^{71}$

Para o musicólogo, o fato de a música antiga latino-americana ser predominantemente religiosa é um dos principais obstáculos ao seu estudo. Isso se dá pois, tanto na América Latina quanto na Europa, a música religiosa não é tão conhecida quanto a profana, existindo uma tendência de se analisar a primeira com uma metodologia própria da segunda, obtendo-se conclusões pouco satisfatórias.

Assim como as pesquisas desenvolvidas por Castagna, o trabalho do cravista e doutor em Musicologia Marcos Holler, Os jesuítas e a música no Brasil colonial, ${ }^{72}$ impressiona pelo fôlego na busca por fontes documentais, neste caso levantadas em arquivos da Companhia de Jesus em Roma, Lisboa e em estados brasileiros como Bahia e Maranhão. Holler sistematiza todas as informações que encontra acerca da atividade musical levada a cabo pelos jesuítas no território colonial português. A partir daí, traça um histórico das discussões acerca da utilização da música por parte da ordem inaciana, relaciona os estabelecimentos onde era ensinada, ocasiões em que era executada, lista instrumentos e personagens emblemáticos, além de apresentar alguns motivos pelos quais a prática musical se desenvolveu mais na América espanhola. Segundo o musicólogo: "Era importante para o processo de catequese isolar os índios do branco colonizador, pois este, além de não ser um bom exemplo,

\footnotetext{
${ }^{70}$ CASTAGNA, P. A. Estilo antigo e estilo moderno na música antiga latino-americana. In: Apostila do curso História da Música Brasileira. São Paulo, Instituto de Artes da Unesp, 2004. p. 8. Disponível em: http://www.ia.unesp.br/Home/AreadoAluno/HMB_2004_apostila05.pdf. Acesso em: 04/03/2014.

${ }^{71}$ Ibidem, pp. 1-2.

${ }^{72}$ HOLLER, Marcos Tadeu. Os jesuítas e a música no Brasil Colonial. Campinas: Editora da Unicamp, 2010.
} 
buscava a escravidão do índio de forma explícita ou velada (...)."73

Enquanto em solo pertencente à Coroa espanhola os jesuítas buscaram estabelecer suas reduções no interior do continente, protegidas dos espanhóis e principalmente dos mestiços bandeirantes que vinham do Norte em busca de índios para serem levados como escravos, no território colonial português, a proximidade das missões com vilas, além do regime de repartição, que dificultava o trabalho dos padres nas aldeias, não permitiam a formação de uma população estável. Assim, a diferença na forma dos aldeamentos teria trazido consequências para produção musical das duas colônias. ${ }^{74}$ Quanto à escassez de fontes documentais sobre música colonial no Brasil, Marcos Holler considera um dos principais motivos a destruição dos manuscritos, entre eles partituras e inventários de instrumentos, no processo de sequestro dos bens dos jesuítas, por ocasião de sua expulsão.

Enquanto o trabalho de Marcos Holler foca na compilação de fontes e no levantamento de informações sobre as práticas musicais, Luisa Tombini Wittmann, em sua tese de doutoramento, ${ }^{75}$ esforça-se por apresentar um universo de constantes negociações, marcado pela presença de práticas musicais e onde diferentes sujeitos históricos reinventaram aspectos de sua vida cultural e social, tendo a música como elemento indispensável. Seu trabalho parte para a constituição de um cenário de trocas culturais entre ameríndios e jesuítas que não se baseia na análise de partituras ou no inventário de instrumentos, mas nos papéis ocupados pela música em um cenário de intenso contato: os aldeamentos. A historiadora inclusive discorda do musicólogo no que diz respeito ao tratamento da música como um elemento prático inserido num trabalho assistencialista jesuítico, o que o trabalho de Holler daria a entender. Sobre a falta da escrita musical no contexto estudado, afirma:

Após o desapontamento inicial, encarei o fato de que a música em si não era o meu enfoque, e que a escolha mais interessante seria mesmo me dedicar com afinco a uma história musical sem sons. (...) Não será via símbolos da notação musical - que se interpretados geram sons - que esta história relacional será reconstruída, mas através da análise de documentos escritos, sobretudo por jesuítas em

${ }^{73}$ HOLLER, Marcos Tadeu. Os jesuítas e a música no Brasil Colonial. Campinas: Editora da Unicamp, 2010. p. 208.

${ }^{74}$ Ibidem, pp. 208-215.

75 WITTMANN, Luisa T. Flautas e maracás: música nas aldeias jesuíticas da América Portuguesa (XVI-XVII). 2011. 266f. Tese de Doutorado em História. UNICAMP, Campinas. 2011. Disponível em: www.bibliotecadigital.unicamp.br/document/?down=000802385. Acesso em: 13/04/2015. 
missão na parte portuguesa da América. ${ }^{76}$

Objetivando, assim, reconstruir esta história de contato não através da música, em sentido estrito, mas das relações sonoras vividas entre os sujeitos envolvidos, Luisa Tombini Wittmann abre espaço para a reflexão sobre o papel da música na cultura indígena, o que geralmente é relegado ao segundo plano. A historiadora se preocupa em estudar as funções das práticas sonoras nas comunidades ameríndias, demonstrando sua importância central e as formas como os jesuítas foram levados a adaptar suas regras ao notarem, na música, um privilegiado canal para o diálogo religioso e posterior conversão. Wittmann ainda descreve algumas características das práticas missionárias no Oriente, possibilitando um cotejo entre as experiências ÁsiaAmérica, a fim de entender melhor as missões ocidentais e ressaltando a questão da adaptabilidade como traço definidor da prática missionária, variando de acordo com o contexto.

Por fim, é preciso citar o competente trabalho de Daniela Ribeiro Pereira. Em sua dissertação de mestrado, ${ }^{77}$ a autora busca traçar uma história social da música nas missões da Companhia de Jesus no Rio da Prata, compreendendo mais de um século (1609-1768) de atividade, o que corresponde praticamente ao tempo de existência da Província Jesuítica do Paraguai. Assim como Wittmann, Pereira também focou nas relações geradas pelas práticas musicais no contexto reducional, buscando entender as funções da música e seu poder de influência.

Para isso, analisa a consolidação dos Trinta Povos fundados pelos jesuítas na Provincia Paracuaria atrás de elementos que favoreceriam e propiciariam o desenvolvimento da música no contexto reducional. Após um levantamento sobre abordagens e conceitos utilizados por outros autores que se debruçaram sobre o tema, faz uma breve reflexão sobre a importância da música para os índios guaranis e então parte para sua tentativa de compreender a dinâmica das práticas musicais como catalisadoras de interesses para a manutenção dos ameríndios reduzidos. Daniela mostra-se atenta no manejo das fontes e preocupa-se em desconstruir a visão de

${ }^{76}$ WITTMANN, Luisa T. Flautas e maracás: música nas aldeias jesuíticas da América Portuguesa (XVI-XVII). 2011. 266f. Tese de Doutorado em História. UNICAMP, Campinas. 2011. Disponível em: www.bibliotecadigital.unicamp.br/document/?down=000802385. Acesso em: 13/04/2015. pp. 19-20.

${ }^{77}$ PEREIRA, D. R. "Si soy misionero es porque canto, bailo y toco música": para uma história social da música na Provincia Paracuaria (1680-1768). 2011. 164f. Dissertação de Mestrado. PUCRS, Porto Alegre. 2011. Disponível em: http://tede.pucrs.br/tde_busca/arquivo.php?codArquivo=3678. Acesso em: 15/04/2015. 
deslumbramento ingênuo dos índios pela música do europeu, buscando mostrar o que eles tinham a ganhar com ela e como se davam as constantes negociações entre missionários e neófitos.

Embora estude um grande espaço de tempo e aborde vários missionários com formação musical, o que acaba não permitindo um maior aprofundamento nas reflexões, não é possível dizer que sua pesquisa tenha caráter panorâmico. Apenas percebe-se que alguns pontos receberam maior atenção da historiadora, o que é compreensível se considerarmos a amplitude do tema.

Seu trabalho foi de extrema importância para esta pesquisa, tendo diversos pontos em comum e dialogando diretamente com ela. Contribuiu, assim, tanto na apresentação de fontes e estudos até então desconhecidos por nós como na colocação de outros questionamentos. Não podemos deixar de destacar a exaustiva prospecção de incidências relacionadas à música nos escritos de Antônio Sepp, levada a cabo pela pesquisadora e apresentada como apêndice de sua pesquisa.

\subsection{Algumas considerações}

Com a leitura das obras apresentadas neste capítulo é possível inferir alguns pontos importantes. A historiografia sobre as missões jesuíticas paraguaias foi, durante muito tempo, quase toda produzida por membros da própria Companhia de Jesus. Com descrições elogiosas e pouco apuro na verificação de informações, estes trabalhos buscaram escrever uma história oficial, construir uma imagem da presença e atuação dos missionários inacianos em terras paraguaias, demonstrando, através de fontes muitas vezes inéditas e disponíveis apenas internamente, os sacrifícios e obstáculos aos quais estavam sujeitos os padres na árdua e gloriosa tarefa de civilizar e catequizar os povos "bárbaros e pagãos", trazendo-os para o seio da cristandade. Nestes estudos, a diversidade étnica e cultural dos indígenas é, geralmente, deixada de lado e predomina a visão do europeu, expressa nas cartas dos missionários ou nos relatos de viajantes.

Notamos, no entanto, que exceções ocorreram e alguns trabalhos, embora apologéticos, refletiram sobre aspectos importantes do contato índios-jesuítas, como a busca pelo entendimento dos papéis da música para as culturas ameríndias e a relevância de elementos culturais na compreensão da estrutura missioneira. Ou então, simplesmente demonstraram preocupação em disponibilizar documentos inéditos 
através de apêndices em suas obras, o que não deve ser desconsiderado. Ao tratarmos de autores considerados aqui como simpatizantes, pudemos ver que o grau de "simpatia" varia muito e se manifesta em âmbitos diversos. Enquanto alguns pesquisadores escrevem como autênticos inacianos, outros tecem elogios a determinados aspectos ou personagens, mas sem a preocupação com a manutenção de determinada imagem oficial.

Com relação àqueles que criticam a ação da Companhia de Jesus e seu projeto missionário, também se nota grande variedade no tom das críticas. Existem pesquisas que desconsideram os trabalhos existentes, por serem apologéticos e não terem nenhum rigor metodológico. Estas buscam desconstruir o já existente e dar início a uma nova linha de estudos, apontando a incapacidade de se produzirem conhecimentos novos a partir de trabalhos tão comprometidos com uma imagem a ser preservada e propagada. Outros, embora critiquem as falhas presentes nos historiadores jesuítas e apresentem suas limitações, partem justamente da contestação destas obras para a construção de suas reflexões, dando os devidos créditos aos aspectos positivos que porventura encontrem nos textos produzidos por estes padres pesquisadores.

O capítulo se ateve mais aos trabalhos incluídos na terceira tipologia, a da crítica histórica. Aí, pudemos notar que tais pesquisadores demonstram maior apuro das fontes e, não preocupados de antemão em elogiar ou criticar os inacianos, atêm-se a seus objetos de pesquisas e seus recortes temporais na busca pela compreensão do contexto histórico e da construção de um quadro mais complexo das relações surgidas do contato entre jesuítas e ameríndios. Com este objetivo, utilizam-se das ferramentas metodológicas de suas especialidades: Musicologia, História, Arquitetura, entre outras. Talvez por isso, muitos deles, sem fazer qualquer tipo de apologia, simplesmente demonstrem apreço por algum aspecto resultante da ação dos jesuítas junto aos nativos, como é caso corrente entre os que estudam manifestações artísticas ou arquitetônicas das missões.

De forma mais ampla, ficou claro que na historiografia em língua portuguesa, são escassas as pesquisas que problematizam os papéis desempenhados pelas práticas musicais no âmbito missioneiro. Alguns dos trabalhos apresentados, como os de Marcos Holler e Luisa Tombini Wittmann, são referências dentro da reflexão neste campo, mas, como o próprio título da pesquisa de Holler indica, trabalham com o tema inserido, em sua maioria, no contexto da América Portuguesa. 
Por fim, posicionando-nos neste debate, creio estarmos entre os pesquisadores da crítica histórica à atuação dos padres jesuítas. Nosso interesse, longe de perpetuar uma história oficial, é tentar apresentar novas visões sobre um tema cuja produção historiográfica vem crescendo nos últimos anos. Não deixamos de salientar a importância dos estudos já realizados, mas nos propomos fazer algo diferente. A partir da crítica às fontes, a maior parte delas produzidas pela própria Companhia e seus membros, como as cartas do padre Sepp ou documentos referentes à administração das reduções, buscamos apresentar hipóteses de como a música se inseria no universo missioneiro e quais os papéis desempenhados por ela neste contexto. Para isso, ao invés de nos basearmos em diversos personagens, em recortes temporais amplos ou abrangendo várias áreas geográficas, nos restringiremos ao estudo das ações de apenas um missionário, o Padre Antônio Sepp, analisando sua formação e atuação em determinadas missões.

Acreditamos que, ainda que em número crescente, faltam pesquisas que tenham clara a relevância da música como instrumento de mistagogia e pedagogia da Contra-Reforma e da construção, nas reduções paraguaias, de uma experiência autorepresentada como uma Nova Jerusalém. Pesquisas que ajudem, portanto, a desconstruir uma visão apologética e limitadora, existente até os dias de hoje. Daí nota-se a consonância deste trabalho com alguns dentre os apresentados neste capítulo no que diz respeito à valorização de aspectos culturais para a compreensão do funcionamento de uma sociedade marcada por profundas mudanças sociais, políticas e econômicas. Além disso, demonstraremos, na medida do possível e até onde as fontes permitirem, a participação dos indígenas neste processo de utilização da música.

Não pretendíamos aqui realizar uma exaustiva análise de todas as obras dos pesquisadores apresentados, até porque a maioria deles possui vasta produção historiográfica e mereceria trabalhos específicos sobre seus estudos. Nossa intenção foi a de contribuir para outras pesquisas, apresentando tanto autores consagrados nesta seara quanto novos nomes, trazendo novas reflexões e pontos de vista. Evidente que, como toda a seleção de trabalhos, corremos o risco de ter deixado autores relevantes de fora. Podemos afirmar, porém, que nos esforçamos para contemplar o máximo de estudos que, de uma maneira ou de outra, contribuíram para o desenvolvimento desta pesquisa. 


\section{ANTÔNIO SEPP: A TRAJETÓRIA DE UM MISSIONÁRIO}

A persuasão dos jesuítas, ainda que levada em conta a necessidade de improvisação, era produto de uma larga reflexão e se caracterizava por ser sistemática e baseada na extensa formação intelectual dos membros da ordem. A historiadora Yara Kassab, ao estudar as estratégias lúdicas dos missionários jesuítas na América, neste caso em terras de colonização portuguesa, afirma:

Falando nas adaptações que os jesuítas adotaram nas terras brasílicas, podemos afirmar que todas tiveram por pilares de sustentação as normas das Constituições. As danças, as músicas, as dramatizações, aqui incluímos as cenas dos autos anchietanos, os instrumentos, entre outros elementos, foram utilizados com consciência e intencionalidade pedagógica, prescritas pelas Constituições. ${ }^{78}$

As próprias missões eram concebidas como cenários detalhadamente planejados nos quais se sucediam múltiplas sugestões e atos dirigidos - inclua-se aí a prática musical - a um mesmo fim: a conversão e controle dos indígenas. ${ }^{79} \mathrm{E}$ é exatamente buscando compreender melhor quem eram estes missionários europeus, formados pela Companhia de Jesus e que, estando alicerçados por textos como as Constituições, a Ratio Studiorum e os Exercícios Espirituais, se utilizavam de ferramentas teórico-metodológicas no trato com os nativos americanos, que o estudo da vida e das atividades do Pe. Antônio Sepp se apresenta como de grande relevância. A prática musical, presente em sua vida desde muito cedo, foi marca registrada de sua atuação tanto como professor em colégios da Companhia na Europa quanto como missionário no Novo Mundo, auxiliando-nos na reflexão sobre os espaços que a música ocupou e conquistou dentro da Ordem dos Jesuítas. Além disso, os muitos anos como mestre de Retórica e Gramática, assim como a autoria e direção de peças teatrais edificantes, mostram um indivíduo extremamente imbuído do projeto pedagógico inaciano. Os mais de 40 anos de trabalho nas reduções ${ }^{80}$, porém, nos

${ }^{78} \mathrm{KASSAB}$, Yara. As estratégias lúdicas nas ações jesuítas, nas terras brasílicas (1549-1597), "para a maior glória de Deus". 2010. Tese de Doutorado em História Social. USP, São Paulo. Ano de obtenção: 2010. p. 129.

${ }^{79}$ Cf. RICO CALLADO, Francisco Luis. Conversión y persuasión en el barroco: propuestas para el estudio de las misiones interiores en la España postridentina. In: Studia Historica. Historia moderna, 24, Ediciones Universidad de Salamanca, 2002, pp.363-386.

${ }^{80}$ Dentre as trinta reduções fundadas pelos jesuítas na Província do Paraguai, Antônio Sepp atuou em onze. A saber: Reyes ou Santos Reis (Magos) de Yapeyú, Encarnación de Itapúa, Santa María de 
revelam um missionário em constante conflito entre necessidades práticas de adaptação que viabilizassem um "encontro catequético" 81 com os guaranis e as regras e preceitos da Companhia de Jesus.

Como nos aponta o pesquisador jesuíta Arthur Rabuske, a vida de Antônio Sepp pode ser dividida em duas grandes etapas: a primeira corresponde aos anos em que esteve na Europa (1655-1691) e a segunda refere-se à sua presença junto aos indígenas, nas reduções paraguaias (1691-1733). ${ }^{82}$ Embora seja o segundo intervalo de tempo aquele que mais nos interessa aqui, estando inclusive no título desta pesquisa e tendo sido, em boa parte, relatado pelo próprio jesuíta em suas cartas, não podemos deixar de nos debruçar também sobre o período anterior, relativo aos anos de formação intelectual e extensa preparação para a vida missionária, pela importância desta etapa em sua atuação no novo continente.

Utilizaremos as etapas propostas por Rabuske como divisoras deste capítulo. Seguiremos os passos de Sepp com a intenção de facilitar a compreensão de aspectos chave de sua atuação como missionário. Ajustaremos as "lentes" de nossa análise, indo do personagem ao contexto e vice-versa sempre que o momento se mostrar favorável à elucidação de pontos caros a esta pesquisa, que permitam um olhar não só sobre os atores sociais, mas também sobre as dinâmicas em que suas ações estão inseridas.

Enquanto a primeira fase terá uma apresentação, acima de tudo, cronológica dos eventos, a segunda seguirá um caminho mais livre temporalmente, destacando acontecimentos específicos, avançando e retrocedendo no tempo para privilegiar alguns aspectos do contexto e da atuação do missionário.

\subsection{A Fase Europeia (1655-1691)}

Antonio Sepp Seppenburg Zu Salegg era muy alemán, pero ello no obstó para que en América, sin claudicar de su íntimo germanismo, llegara a ser muy español, como él mismo nos lo dice, y lo que es más, aunque él no lo dice, muy indio. Es que por encima de todo germanismo y de todo hispanismo había un elemento capaz de

Fé, San Ignácio Guazu, San Carlos, San Javier, São Miguel (Arcanjo), São João Batista, São Luís Gonzaga, La Cruz e San José.

${ }^{81}$ AGNOLIN, Adone. O governo das almas indígenas: missão jesuítica e ritualidade indígena (séc. XVI-XVII). In: SOUZA, Laura de Mello e; FURTADO, Júnia Ferreira; BICALHO, Maria Fernanda (orgs.) O governo dos povos. São Paulo: Alameda, 2009. p. 217.

82 RABUSKe, Arthur S.J. Pe. Antônio Sepp, SJ - O Gênio das Reduções Guaranis. 3.ed. São Leopoldo: Editora Unisinos, 2003. p. 13. 
congeniar ambos elementos, posiblemente contrarios o antagónicos y plasmarlos en la pasta indígena: el ideal religioso. ${ }^{83}$

Nascido no dia 21 de dezembro de 1655, em Kaltern, no Tirol alemão (atualmente território italiano), Antônio Clemente Sepp recebeu seu nome em homenagem ao padroeiro franciscano Santo Antônio de Pádua e a São Clemente I, celebrado no dia 23 de novembro (data do batismo de Sepp) segundo o antigo calendário litúrgico. Este fato já nos permite entrever a influência católica de sua família, ${ }^{84}$ na qual dos onze irmãos (Antônio Sepp é o quinto), cinco seguiram vocações religiosas, sendo um agostiniano, dois beneditinos (um irmão e uma irmã) e um padre secular, além do próprio Sepp, jesuíta. Vale salientar que os onze filhos receberam nomes de santos e santas da Igreja Católica.

Antônio obteve sua formação inicial em escolas da região, em Kaltern e Eppan, tendo depois dirigido-se a Viena, onde chamou a atenção por seus dotes musicais. Aparentemente, a música esteve presente em sua vida desde muito cedo, já que entre seus irmãos mais velhos dois também apresentaram talentos musicais, tendo um deles, Paulo Sepp, se tornado músico de ofício. Segundo Rabuske, era costume das famílias nobres austríacas investirem na formação artístico-musical de seus filhos. ${ }^{85}$ Além disso, de acordo com Johann Mayr, nas escolas destes pequenos vilarejos, o professor, contratado por uma espécie de Conselho Municipal, mais do que apenas ensinar as crianças a ler e escrever, acumulava a função de organista tanto na matriz quanto nas igrejas secundárias. ${ }^{86} \mathrm{E}$ não é difícil supor a existência de pequenos corais de meninos cantores, onde Antônio Sepp possa ter figurado.

Fato é que, entre os anos de 1664 e 1667, tornou-se membro do coral "Meninos Cantores da Corte de Viena", função para a qual eram selecionadas apenas 6 crianças em todo o território da Áustria. Neste período, que durou dos nove aos doze ou treze anos, aprendeu, além do canto, a tocar diversos instrumentos musicais, principalmente órgão. O próprio imperador Leopoldo I (1640-1705) participava da

${ }^{83}$ FURLONG, Guillermo S.J. Antonio Sepp y su "gobierno temporal" (1732). Buenos Aires: Ediciones Theoria, 1962. p. 8.

${ }^{84}$ Existem indícios de certa nobreza na família Sepp, principalmente pela parte materna. Arthur Rabuske, S.J., tomando por base o trabalho de fôlego de outro jesuíta, o alemão Johann Mayr, apresenta um breve histórico dos pais e da família do missionário. Para mais, ver RABUSKE, Arthur S.J. Pe. Antônio Sepp, SJ - O Gênio das Reduções Guaranis. 3.ed. São Leopoldo: Editora Unisinos, 2003. 43-53.

${ }^{85}$ Ibidem, p. 68.

${ }^{86}$ MAYR, Johann. Anton Sepp: Ein Südtiroler im Jesuitenstaat. Verlagsnstalt Athesia, Bozen, 1988. 480p. apud RABUSKE, op. cit. p. 70. 
seleção dos jovens integrantes de seu coral.

Arquiduques da Áustria, os príncipes da casa de Habsburgo eram também, no século XVII, imperadores do Sacro Império Romano-Germânico e reis da Boêmia e da Hungria, esta reduzida à chamada Hungria real, pois a maior parte do território estava ocupada pelos Turcos desde o século XVI. Eram famosos por sua musicalidade e por um apreço pelas práticas musicais que agiu como um verdadeiro catalisador para a crescente importância de Viena como um centro musical na Europa. Segundo o músico e pesquisador Timothy Paul Westerhaus:

The Habsburg emperors who reigned from 1619 to 1720 exemplified pious Catholicism and perpetuated an aggrandized view of themselves both within and outside the Holy Roman Empire. Furthermore, each emperor placed an exceptionally high value upon music in his personal life and in the life of the court. ${ }^{87}$

Dentre aqueles a quem podemos chamar de "imperadores musicistas", Leopoldo I se destaca como sendo o compositor mais producente, o instrumentista mais hábil e um grande patrono musical da vida cortês. Não estava destinado a tornarse sucessor do trono; segundo filho de Fernando III (1608-1657), seria encaminhado à carreira clerical. Desta forma, sua educação ficou a cargo dos jesuítas, que garantiram ao futuro imperador uma ampla formação humanística. Mesmo falando diversas línguas e tendo habilidades poéticas, destacou-se na música: além de ser capaz de tocar vários instrumentos, como violino e cravo, foi instruído em composição.

Em 1654, com apenas 14 anos, tornou-se herdeiro quando seu irmão morreu de forma inesperada. Ele foi coroado imperador do Sacro Império Romano em 1658, quando Antônio Sepp contava apenas três anos de idade. Durante seu reinado, Leopoldo I promoveu fortemente a vida musical, especialmente o teatro musical, ao qual estava particularmente ligado. Considerando que entre 1630 e 1657 o número de apresentações de musicais somaram 16, entre 1658 e 1675 havia nada menos do que $400 .^{88}$ Estas tomaram a forma de, por exemplo, óperas, dramas carnavalescos seculares, oratórios durante a Quaresma, performances em ocasião de aniversários ou dias de santos. Como um patrono das artes, Leopoldo I ampliou e reorganizou a

\footnotetext{
${ }^{87}$ WESTERHAUS, Timothy Paul. The Baroque Requiem Mass at the imperial Habsburg Court in Vienna: musical and historical context, rhetoric, and signification. 2013. Thesis (D.M.A.), Boston University. 2013. pp. 1-2. Disponível em: http://hdl.handle.net/2144/11085. Acesso em: 05/05/2015.

${ }^{88}$ Ibidem, pp. 33-34.
} 
capela imperial, tendo em 1696 estabelecido a posição de compositor da corte. O número de músicos aumentou e, uma vez que foram predominantemente recrutados na Itália, isso fortaleceu a influência italiana no estilo musical vienense, em detrimento da influência francesa. Esta perdeu espaço devido aos atritos políticos entre o imperador e seu primo, o monarca Luís XIV. Segundo os musicólogos Donald J. Grout e Claude V. Palisca:

A primazia musical da Itália durante o período barroco não foi absoluta, mas mesmo os países que desenvolveram e conservaram o idioma nacional próprio não escaparam à influência italiana. (...) No final do período barroco, com efeito, a música da Europa tinha-se convertido numa linguagem internacional com raízes italianas. ${ }^{89}$

Prova do predomínio italiano quanto ao estilo musical é que, em 1679, o imperador nomeou o primeiro mestre de capela vienense não originário da Itália, desde 1619. Era ele o renomado violinista austríaco Johann Heinrich Schmelzer (c. 1620-1680). Quando Antônio Sepp já atuava como missionário em terras paraguaias, são peças de Schmelzer, além das de Johann Melchior Gletle (1626-1683), as que solicita aos seus irmãos de ordem, pedindo veementemente que as enviasse ao novo continente para que servissem de base na composição de peças a serem utilizadas em seus trabalhos nas missões. Como não restaram, ou ainda não foram descobertas, partituras cuja autoria seja atribuída ao padre Antônio Sepp, conhecer suas referências musicais serve de pista importante para compreendermos melhor sua atuação como músico e professor de música.

O imperador Leopoldo I não contou só com seus músicos, mas também estava envolvido na criação do repertório musical de sua corte. Além de contribuir para composições que tinha encomendado de seus compositores, também compôs uma quantidade considerável de obras. Estas composições incluem uma ampla gama de gêneros musicais e abarcam obras litúrgicas e seculares, como óperas, oratórios, madrigais, sonatas, danças, canzonettas, massas, antífonas, motetos, hinos etc.

Considerando a quantidade de problemas políticos durante seu reinado (por exemplo: grande praga de Viena em 1679; cerco de Viena pelo Império Otomano em 1683; o expansionismo de Luís XIV de França), o crescimento cultural na corte durante a vida de Leopoldo I é impressionante, ainda mais se tivermos em mente que,

${ }^{89}$ GROUT, Donald. J., PALISCA, Claude V. História da música ocidental. Revisão Técnica de Adriana Latino; tradução Ana Luísa Faria. Lisboa: Gradiva, 1994. p. 309. 
durante este período, Viena fortaleceu sua posição como centro musical de destaque na Europa. ${ }^{90}$

Toda a importância histórica deste personagem, assim como o ambiente de proeminência cultural vivida pela corte vienense em meados do século XVII, nos dão uma ideia da relevância da escolha de Antônio Sepp para o restrito grupo de meninos cantores e das influências de estilo que marcaram sua formação musical. Não podemos, desta forma, desconsiderar a hipótese de que desde muito cedo as habilidades de Sepp chamassem a atenção.

Sabe-se, inclusive, que em algum momento durante o ano de 1667, o jovem, então com onze para doze anos, fez uma viagem até a Inglaterra. ${ }^{91}$ Não se tem certeza, porém, dos motivos deste deslocamento. Supomos que seus talentos musicais tenham despertado o interesse de possíveis patronos. Segundo Guillermo Furlong: "(...) estuvo en Inglaterra y tuvo trato con personas de jerarquía y prestancia, hasta el punto de sentir el mareo que producen en la juventud los honores, lujos y boatos de las cortes y de los cortesanos." 92

Também o próprio Sepp nos dá indícios favoráveis a esta hipótese. Em sua carta de felicitação ao novo geral da Ordem, Pe. Charles de Noyelle, escolhido para o cargo em 1682, aproveitou para solicitar autorização de servir como missionário nas Índias. Entre os argumentos, apresenta o fato de ter preterido, quando teve possibilidade, uma vida cortesã em favor da religiosa:

Se eu não faltar naquilo que me cabe, então aquele Deus que chama tanto as coisas que são como as que não são, dará Sua graça ao pecador. Isto, sobretudo, se eu considerar a sua Infinita Misericórdia, pela qual já outrora, quando fora chamado à Inglaterra em atenção do lucro ou do favor agraciado dos príncipes, contudo me fez preferir o seguimento de seu Filho pobre e desprezado na

${ }^{90}$ Para mais sobre Leopoldo I e sua relação com a música, ver: WESTERHAUS, Timothy Paul. The Baroque Requiem Mass at the imperial Habsburg Court in Vienna: musical and historical context, rhetoric, and signification. 2013. Thesis (D.M.A.), Boston University. 2013. Disponível em: http://hdl.handle.net/2144/11085. Acesso em: 05/05/2015. pp. 25-41.

${ }^{91} \mathrm{O}$ reino, que há menos de uma década havia restaurado a monarquia parlamentarista sob o jugo de Carlos II, voltava suas atenções aos acordos que culminaram no Tratado de Breda. Tal acordo, assinado pela República das Sete Províncias Unidas dos Países Baixos, pelo Reino da GrãBretanha, da França e da Dinamarca no dia 31 de julho daquele ano, pôs fím à segunda guerra anglo-holandesa (1665-1667) que, vencida pelos holandeses, envolvia a disputa pelo controle de rotas comerciais de navegação. Ver: MAHN, A. T. The influence of Sea Power uppon History, 1660-1783. Cambridge University Press, 2001.

92 FURLONG, Guillermo S.J. Antonio Sepp y su "gobierno temporal" (1732). Buenos Aires: Ediciones Theoria, 1962. p. 9. 
sua Companhia, a buscar as coisas deste mundo. ${ }^{93}$

Independente do motivo, a jornada parece não ter sido bem sucedida, já que no ano seguinte o encontramos de volta ao Tirol, fora do coro de meninos cantores da corte vienense e realizando seus estudos ginasiais no Colégio dos Jesuítas de Innsbruck, onde permaneceria por sete anos.

Vale ressaltar que o criador da ordem, Inácio de Loyola, considerava a atividade pedagógica tão essencial à Companhia de Jesus quanto a pregação e a administração dos sacramentos. ${ }^{94}$ No período em que Sepp iniciou sua formação, os colégios jesuítas já contavam com mais de cem anos de experiência pedagógica, alicerçada em uma série de regras presentes na Ratio studiorum..$^{95}$ E embora não haja menção à música neste documento central da pedagogia inaciana, o crescimento das instituições escolares da Companhia de Jesus teve papel fundamental no fortalecimento das práticas musicais por parte dos membros da ordem.

Mesmo que não fosse primordial, a música conquistou seu espaço a partir de seu valor como instrumento pedagógico. Ainda que inicialmente executada por religiosos externos à Companhia, ou por profissionais contratados, no decorrer dos anos já vemos professores jesuítas (estudantes em processo de ordenação) atuando nos colégios à frente de aulas de música, corais e representações teatrais, sempre com acompanhamento musical. Não é algo digno de espanto, se pensarmos que muitas das crianças formadas nestas instituições posteriormente viriam a ingressar nas fileiras da ordem, trazendo consigo toda a bagagem, inclua-se a musical, absorvida durante os anos de formação. É o caso de Antônio Sepp, como veremos mais adiante.

Luisa Tombini Wittmann afirma que "a expansão dos colégios jesuíticos fez com que a música se tornasse parte importante do currículo e do cotidiano escolar na

${ }^{93}$ Carta latina de 19 de setembro de 1682, desde Lucerna, endereçada ao Geral dos Jesuítas em Roma. Arquivo Romano da Companhia de Jesus, Fondo del Gesù, Indipetae 23, 247. Tradução vernácula de Arthur Rabuske. In: Pe. Antônio Sepp, SJ - O Gênio das Reduções Guaranis. 3.ed. São Leopoldo: Editora Unisinos, 2003., pp. 86-87.

$94 \mathrm{KASSAB}$, Yara. As estratégias lúdicas nas ações jesuítas, nas terras brasílicas (1549-1597), "para a maior glória de Deus". 2010 Tese de Doutorado em História Social. USP, São Paulo. Ano de obtenção: 2010. p. 32.

95 A codificação do Plano de Estudos da Companhia de Jesus - o Ratio atque Institutio Studiorum Societatis Jesu -, redigido por comissões de destacados jesuítas, sob a direção do Geral da Ordem, P. Acquaviva, submetido a várias análises e alterações, até adquirir forma definitiva e obrigatoriedade em 1599, tem por cerne o objetivo de assegurar a uniformidade de procedimentos, de mente e coração dos educadores jesuítas e dos alunos, para a consecução dos objetivos propostos. Para mais, ver: BRIZZI, G. P. (ed.). La ratio Studiorum. Modelli culturali e pratiche educative dei Gesuiti in Italia fra cinquecento e seicento. Roma: Bulzoni. 1981. 
Europa." 96 Com o Colégio de Innsbruck não era diferente. Contava com coros ginasiais (dois dos irmãos de Sepp aparecem listados como integrantes por diversos anos) e encenações teatrais em datas comemorativas do calendário cristão, interpretadas por alunos e professores e voltadas ao público em geral. Em uma delas, encenada em 1672 e de nome Xaverianum suspirum (Suspiro Xaveriano), Antônio Sepp aparece na relação de atores, desempenhando o papel de personagem principal, São Francisco Xavier. ${ }^{97}$

\subsubsection{A música nos colégios da Companhia de Jesus}

Ao tratarmos da formação recebida por Antônio Sepp durante os anos passados em um colégio jesuíta, vale abrirmos um breve parêntese com o objetivo de detalhar melhor a questão da música para os inacianos.

A Igreja Católica, em geral, sempre se preocupou em normatizar a prática musical em suas cerimônias religiosas. Geralmente, tentava evitar as alterações que desviassem a música de padrões estabelecidos oficialmente, procurando manter os modelos tradicionais romanos. No entanto, eventualmente admitia práticas já estabelecidas por costume. Segundo Paulo Castagna:

Encíclicas, Decretos e os mais variados tipos de determinações foram emitidos para controlar a prática musical, proibindo os cânticos que subvertessem os ideais católicos e regulamentando aqueles que contribuíssem para a unidade cristã. ${ }^{98}$

Já para a Companhia de Jesus, a utilização da música sempre gerou discussões. Inácio de Loyola acreditava que a prática musical absorveria os padres, tirando-lhes a atenção das tarefas do cotidiano, e lembrava o compromisso da ordem com o "cuidado dos bens espirituais", que envolviam desde a administração da comunhão até a catequese. Tais cuidados necessitavam de atenção contínua e não abririam espaço para a prática musical.

96 WITTMANN, Luisa T. Flautas e maracás: música nas aldeias jesuíticas da América Portuguesa (XVI-XVII). 2011. 266f. Tese de Doutorado em História. UNICAMP, Campinas. 2011. p. 45. Disponível em: www.bibliotecadigital.unicamp.br/document/?down=000802385. Acesso em: 13/04/2015.

${ }^{97}$ MAYR apud RABUSKe, Arthur S.J.. Pe. Antônio Sepp, SJ - O Gênio das Reduções Guaranis. 3.ed. São Leopoldo: Editora Unisinos, 2003. pp. 73-74.

98 CASTAGNA, P. A. Cantochão e liturgia: implicações na pesquisa da música católica latinoamericana (séculos XVI-XX). In: IV SIMPÓSIO LATINO-AMERICANO DE MUSICOLOGIA, Curitiba, 20-23 jan. 2000. Anais. Curitiba, Fundação Cultural Curitiba, 2001, p. 199-222. 
Após uma imposição do papa Paulo IV, a Companhia de Jesus permitiu a utilização de música em suas cerimônias, mas com diversas restrições, que se alteravam no decorrer dos anos e de acordo com a localidade. ${ }^{99} \mathrm{E}$ isso porque, apesar de a ordem ter um posicionamento contrário às práticas musicais, as necessidades apostólicas acabaram evidenciando o valor das manifestações sonoras não só nas atividades litúrgicas, atraindo fiéis, quanto nas pedagógicas. Isto acabou por propiciar o desenvolvimento de uma tradição musical nas igrejas e colégios inacianos na Europa. Durante este processo de rejeição, imposição, aceitação e utilização que, longe de ser linear, durou quase um século, as diretrizes gerais da Companhia de Jesus foram, em muitos casos, adaptadas pelos padres provinciais, que nem sempre estavam de acordo com elas. Conforme nos conta Wittmann:

O mais famoso caso de discórdia sobre a música parece ter sido o do colégio jesuítico de Viena, cujo reitor Nicolau Lanoy foi advertido e até mesmo penalizado por Loyola. No espaço que havia sido um monastério Carmelita [sic], e inclusive possuía um órgão, jesuítas e irmãos realizavam missas e ofícios cantados, conforme costume antigo do local. ${ }^{100}$

No que se refere particularmente aos colégios jesuíticos da Europa no século XVII, as práticas musicais se firmaram conforme as especificidades de cada região. $\mathrm{O}$ crescimento se deu em maior intensidade justamente nos colégios de cidades como Viena e Praga, em regiões onde a formação musical dos padres e do povo era mais significativa. ${ }^{101} \mathrm{~A}$ inclusão de práticas musicais ocorreu em diversos âmbitos, como, por exemplo, em celebrações litúrgicas, cultos de devoção mariana ou, como vimos no caso do colégio de Innsbruck e através da participação de Antônio Sepp e seus irmãos, em encenações teatrais e coros estudantis, utilizados como um método pedagógico eficaz para o ensino da doutrina católica.

Em todo caso, levando em conta as afirmações de Wittmann e o contexto histórico do Sacro Império Romano-Germânico, com toda a efervescência cultural promovida pelo imperador Leopoldo I, podemos afirmar que Antônio Sepp se encontrava em um terreno privilegiado para o desenvolvimento de suas habilidades

\footnotetext{
${ }^{99}$ Cf. HOLlER, Marcos Tadeu. Os jesuítas e a música no Brasil Colonial. Campinas: Editora da Unicamp, 2010. pp. 138-63.

100 WITTMANN, Luisa T. Flautas e maracás: música nas aldeias jesuíticas da América Portuguesa (XVI-XVII). 2011. 266f. Tese de Doutorado em História. UNICAMP, Campinas. 2011. p. 40. Disponível em: www.bibliotecadigital.unicamp.br/document/?down=000802385. Acesso em: 13/04/2015.

${ }^{101}$ Ibidem, p. 43.
} 
musicais, em uma zona de "exceção" às normas proibitivas da Companhia de Jesus no que tange à utilização da música. O imperador, formado por jesuítas e certamente conhecedor das regras e preceitos da ordem, exercia pressão suficiente no sentido de favorecer as práticas musicais em cerimônias religiosas e na formação dos jovens. ${ }^{102}$ Além disso, não devemos nos esquecer que a utilização de música por parte da Igreja luterana era um grande atrativo aos fiéis, o que também levantava questionamentos por parte do clero católico local acerca dos benefícios de proibições relativas à música.

\subsubsection{Entrada para a Companhia de Jesus, formação e atuação como professor}

Após concluir o ginásio no colégio jesuíta de Innsbruck, Antônio Sepp entrou para a Companhia de Jesus, aos 19 anos de idade. Seu ingresso se deu na Província da Alemanha Superior, que abrangia juridicamente os territórios da Baviera, da Suábia, Suíça e todo o Tirol austríaco e italiano (de hoje), onde se incluía até a região de Trento. Tais informações serão importantes quando abordarmos sua solicitação para ir às missões. A casa de formação a que se dirigiu foi a de Landsberg, na Baviera Superior, tendo iniciado sua preparação no dia 28 de setembro de 1674.

A formação dos jesuítas, semelhante até os dias atuais, começa no noviciado, que dura dois anos. Este período serve como uma fase de teste quanto às disposições do pretendente ao ingresso na ordem. Os noviços devem examinar suas vocações e provar que reúnem as condições exigidas para assumir a vida religiosa. Ao fim deste período, o candidato professa seus primeiros votos religiosos (pobreza, castidade e obediência) ${ }^{103}$ o que Antônio Sepp fez em 29 de setembro de 1676.

Passado este biênio, tem início o período de formação científica, no qual os recém-professos assistem a três matérias de nível superior. São elas: Humanidades (ou Letras Clássicas), Filosofia Escolástica e Teologia. Somente quando concluem os ensinamentos finais, os teológicos, os estudantes são ordenados, passando ao subdiaconato, diaconato e presbiterato. Segundo Rabuske, os candidatos atingem o

102 WESTERHAUS, Timothy Paul. The Baroque Requiem Mass at the imperial Habsburg Court in Vienna: musical and historical context, rhetoric, and signification. 2013. Thesis (D.M.A.), Boston University. 2013. p. 30. Disponível em: http://hdl.handle.net/2144/11085. Acesso em: 05/05/2015

103 Para mais sobre os votos feitos pelos jesuítas, Cf. Constituições da Companhia de Jesus e Normas Complementares. São Paulo: Loyola, 2004 (1558), p. 46. Disponível em: http://books.google.com.br/books?id=TF3d94YuJYoC\&printsec=frontcover \&hl=pt-

$\mathrm{BR} \&$ source=gbs_ge_summary_r\&cad=0\#v=onepage \&q\&f=false. Acesso em: 11/05/2015. 
sacerdócio por volta dos 31 a 33 anos. ${ }^{104}$

Logo após concluir seu curso filosófico, Antônio Sepp foi enviado para lecionar no ginásio da Companhia em Landsberg. Este período de magistério fazia parte do que os jesuítas chamavam de interstício, caracterizado como uma espécie de estágio prático a ser cumprido durante o período de formação religiosa e científica. Nesta função, exercida nos colégios de Landsberg, Lucerna e Solothurn, o estudante Sepp permaneceu por cerca de cinco anos (entre 1679 e 1683).

Como relatamos anteriormente, a utilização da música pela Companhia de Jesus foi permitida em grande parte devido ao seu valor pedagógico. Ela poderia ser executada e ensinada conquanto não ocupasse os religiosos inacianos, tirando-os de suas atividades espirituais. E certamente os estudantes que cumpriam o interstício magisterial serviram muito bem a esta tarefa. No caso de Antônio Sepp, suas atividades nos colégios em que lecionou não se limitaram às aulas. Foi não só professor de Gramática, Retórica e Humanidades (Línguas Clássicas), mas também de Música, tendo ainda escrito e dirigido peças teatrais edificantes. Seus talentos musicais fizeram com que se tornasse prefeito de música e regente do canto coral, em um período que certamente serviu para que se aperfeiçoasse ainda mais no estudo da música, religiosa e profana. Como nos informa Daniela Ribeiro Pereira:

Em 1688 se encontra em Augsburgo como professor de retórica e "praefectus musicae", enquanto mantinha contato com o diretor de música da catedral, Johan Melchior Gletle, num círculo onde a renovação da polifonia e a novidade do estilo moderno despontavam. ${ }^{105}$

Como dissemos acima, tanto Gletle, reconhecido compositor de música sacra, quanto Schmelzer foram grandes influências na formação de Sepp e acabaram servindo como referências às pequenas peças que compunha para uso litúrgico nas reduções.

$\mathrm{Na}$ historiografia sobre as missões jesuíticas é comum encontrarmos referências às habilidades musicais de Antônio Sepp, deixando transparecer um certo

104 RABUSKe, Arthur S.J.. Pe. Antônio Sepp, SJ - O Gênio das Reduções Guaranis. 3.ed. São Leopoldo: Editora Unisinos, 2003. p. 77. É possível verificar as etapas da formação dos membros da Companhia de Jesus no site da ordem. Disponível em: http://www.jesuita.org.br/vocacao-jesuitaetapas-de-formacao-do-jesuita/. Acesso em: 08/05/2015.

105 PEREIRA, D. R. "Si soy misionero es porque canto, bailo y toco música": para uma história social da música na Provincia Paracuaria (1680-1768). 2011. 164f. Dissertação de Mestrado. PUCRS, Porto Alegre. 2011. p. 109. Disponível em: http://tede.pucrs.br/tde_busca/arquivo.php?codArquivo=3678. Acesso em: 15/04/2015. 
senso comum quanto à genialidade do jesuíta. Porém, alguns pesquisadores, inclusive da própria ordem, apresentam visões que contradizem este cenário, destacando seu valor como instrumentista, instrutor musical e luthier, ${ }^{106}$ mas relevando seus dotes artísticos para a composição e apontando para possíveis "exageros" tanto de pesquisadores do tema quanto de jesuítas e observadores contemporâneos ao missionário. Segundo Guillermo Furlong S.J.:

Sepp, como músico, estaba muy lejos de ser un Zipoli, ${ }^{107}$ como parecería que le consideraban algunos jesuitas alemanes de la época, que le conocieron y trataron en América, y como se expresaron, entre otros, los Padres Lozano y Peramás. Los asertos de éstos son, a las veces, en términos tales que se creería que Sepp era un maestro consumado en música y un compositor exímio, capaz de figurar entre los notables maestros de Capilla de Europa, pero no era así. Había en él un músico capaz de apreciar y ejecutar las obras ajenas, y hasta componer algunas cositas de su propria cosecha, y sabía tocar diversos instrumentos musicales, teniendo gran habilidad de fabricarlos con la ayuda de sus indios. ${ }^{108}$

Com isso, o que gostaríamos de ressaltar é que, muito provavelmente, Antônio Sepp se destacou mais por suas habilidades técnicas, como instrumentista e luthier, do que pelas artísticas, como "compositor exímio" e diferenciado. Voltaremos a este ponto quando abordarmos o papel da música nas missões.

Retornando à formação do jovem religioso, sabemos, através das fontes coletadas por Mayr, que foi durante a realização dessa etapa do interstício que o jovem religioso manifestou institucionalmente sua vontade de servir como missionário nas Índias. Sepp aproveitou-se da nomeação de um novo Geral da Ordem, o Pe. Charles de Noyelle (1615-1686), e endereçou a ele uma carta de felicitações acompanhada de seu pedido, "manifestação de intensa disposição", no dia 19 de setembro de $1682 .{ }^{109}$ Esperaria sete anos, porém, até ver o deferimento de sua

106 "Lutherie [Fr.]. Lute making; by extension, the making and repair of any stringed instruments, especially those of the violin family." In: RAENDEL, Don Michael. The Harvard Dictionary of Music. 4th ed. Cambridge, Massachusetts and London, England. The Belknap Press of Harvard University Press. 2003 (1986). p. 477.

107 Contemporâneo do Pe. Sepp, o organista e compositor Domenico Zipoli (1688-1726) criou diversas obras sacras para as missões jesuíticas dos atuais Paraguai e Bolívia, sendo reconhecido por muitos especialistas como um dos compositores de maior prestígio dentro da Companhia de Jesus. Para mais, Cf. SZARÁN, Luis. Domenico Zipoli (1688-1726): Una vida, un enigma. Nurenberg: Fundación Paracuaria - Missionsprokur S.J., 2005.

${ }^{108}$ FURLONG, Guillermo S.J. Antonio Sepp y su "gobierno temporal" (1732). Buenos Aires: Ediciones Theoria, 1962. pp. 63-64.

${ }^{109}$ MAYR apud RABUSKe, Arthur S.J.. Pe. Antônio Sepp, SJ - O Gênio das Reduções Guaranis. 3.ed. São Leopoldo: Editora Unisinos, 2003. pp. 86-87. 
solicitação.

Portanto, voltou à Universidade de Ingolstadt em 1683 para completar sua instrução científica. Durante os quatro anos seguintes, realizou seus estudos de teologia, nos quais teve de enfrentar especulações doutrinárias e relacionadas à questão da salvação, da missão junto aos "povos pagãos". Após a conclusão desta graduação, deveria submeter-se aos exames finais, conforme o artigo 518, capítulo II, da Quinta Parte das Constituições da Companhia de Jesus, que versa sobre as "Qualidades dos que hão de admitir":

Por isso, para alguém ser admitido à profissão, será conveniente que se tenha dado ao estudo da teologia por todo esse tempo, e que nela tenha feito bons progressos para glória de Deus Nosso Senhor. Como prova do seu aproveitamento, deverá cada um, antes da profissão, defender tese de lógica, filosofia e teologia escolástica, diante de quatro examinadores designados para arguir e julgar com toda a verdade e sinceridade se, em seu sentir, ele atinge um nível satisfatório. Se se visse que lhe faltavam suficientes conhecimentos, seria preferível esperar até que os alcance. De igual modo devem ser adiados aqueles que, na abnegação de si mesmos e nas outras virtudes religiosas, não deram provas plenamente satisfatórias. ${ }^{110}$

Ao que tudo indica, Sepp apresentou dificuldades nestes testes:

Durante los exámenes que siguieron a sus estudios de filosofia y teología no se había desempeñado en forma tal que, a juicio de los jueces, mereciera la Profesión de cuatro votos, y así sólo llegó a ser Coadjutor Espiritual, pero no Profeso. ${ }^{111}$

Também os votos religiosos que o jesuíta pronuncia até se unir em definitivo à Companhia de Jesus apresentam-se diversos, podendo ser os de professo de quatro votos, os de coadjutor espiritual ou coadjutor temporal. Como nos aponta Furlong, o futuro missionário não chegou a ser professo de quatro votos na ordem, tendo atingido apenas o nível hierárquico de coadjutor espiritual. ${ }^{112}$

${ }^{110}$ CONSTITUIÇõeS da Companhia de Jesus e Normas Complementares. São Paulo: Edições Loyola, 2004. (1558). pp. 153-154. Disponível em: http://books.google.com.br/books?id=TF3d94YuJYoC\&printsec=frontcover\&hl=ptBR\&source=gbs_ge_summary_r\&cad=0\#v=onepage\&q\&f=false. Acesso em: 11/05/2015.

111 FURLONG, Guillermo S.J. Antonio Sepp y su "gobierno temporal" (1732). Buenos Aires: Ediciones Theoria, 1962. p. 54.

112 As Constituições da Companhia de Jesus distinguem quatro "categorias de pessoas que se admitem". São elas: professos de quatro votos, coadjutores (espirituais ou temporais), escolásticos e aqueles "admitidos indeterminadamente em relação ao grau para o qual com o tempo se revelarem mais aptos". Quanto aos coadjutores, diz o artigo treze: "(...) compõe-se daqueles que são recebidos como coadjutores para o serviço divino e auxílio da Companhia nas coisas espirituais ou temporais. 
Com o término de seus estudos de graduação em Filosofia e Teologia, Antônio Sepp encaminhou os preparativos para sua ordenação sacerdotal. Sendo assim, foi-lhe conferida a ordem do subdiaconato no dia 22 de fevereiro de 1687. Um mês depois, em 15 de março, ordenou-se diácono. Tornou-se presbítero no dia 24 de maio de 1687, em celebração ocorrida na Catedral de Augsburgo. Então com 32 anos de idade, tornava-se o terceiro membro de sua família a receber ordenação presbiterial.

Antônio Sepp, agora presbítero, deveria ser conduzido à etapa final de sua formação jesuítica mediante a realização da terceira provação, ou terciado, em Altötting, localidade que possuía uma casa especialmente destinada a receber os sacerdotes nesta fase. Seu retiro, porém, acabou postergado pelo período de um ano, no qual foi solicitado para atuar novamente como professor ginasial de Retórica, agora no Colégio de Augsburgo.

O terciado baseia-se em um período de formação intensa, de aperfeiçoamento do recém-jesuíta na vida específica da Companhia. Tais objetivos eram buscados com a utilização de ferramentas características da formação inaciana: a realização do retiro grande de trinta dias, o aprofundamento da espiritualidade da Ordem, o estudo de suas Constituições e a preparação imediata para o trabalho pastoral. Essas práticas se apresentavam como modos concretos de vivência dos Exercícios Espirituais sugeridos pelo fundador da Companhia, Inácio de Loyola. Toda esta trajetória acontecia sob a direção de um instrutor, geralmente um padre experimentado no espírito inaciano.

No entanto, Sepp não conseguiu dedicar-se plena e permanentemente a esse propósito, pois novamente fora requisitado para atuar, de forma temporária, no magistério, desta vez no Colégio de Landshut. De qualquer forma, ao final desse período, em março de 1689, seu provincial lhe concedeu o certificado de missionário

Estes, depois das devidas experiências e provações, hão de fazer os três votos simples de obediência, pobreza e castidade, sem o quarto de obediência ao Papa, nem algum outro voto solene. E hão de alegrar-se com o seu grau, pois sabem que, aos olhos de nosso Criador e Senhor, os que mais merecem são os que se dão a ajudar e servir a todos com maior caridade, por amor de sua divina Majestade, quer nas coisas de maior importância, quer nas mais baixas e humildes." Ver: CONSTITUIÇÕES da Companhia de Jesus e Normas Complementares. São Paulo: Edições Loyola, 2004. (1558). p. 46-47. Disponível http://books.google.com.br/books?id=TF3d94YuJYoC\&printsec=frontcover\&hl=pt-

$\mathrm{BR} \&$ source $=\mathrm{gbs} \_g e \_s u m m a r y \_r \& c a d=0 \# \mathrm{v}=$ onepage $\& \mathrm{q} \& \mathrm{f}=$ false. Acesso em: 11/05/2015. Ainda segundo os artigos 112 e 113 das Constituições: "Os coadjutores espirituais são sacerdotes com suficiente instrução intelectual para ajudar nos ministérios espirituais.", existindo uma diferenciação entre coadjutores espirituais e temporais na qual "pertence mais aos primeiros ajudar a Companhia nas confissões, exortações, ensino da doutrina cristã ou de outras matérias no campo da instrução. Poderão ser-lhes comunicados os mesmos privilégios que aos professos para auxílio das almas." CONSTITUIÇÕES, op. cit., pp. 66-67. 
paraguaio. $^{113}$

\subsubsection{Solicitação para ir às Missões}

É importante lembrarmos que a Companhia de Jesus, fundada por Inácio de Loyola e criada oficialmente em 1540, através da Bula Regimini militantis Ecclesiae do papa Paulo III, surgiu em pleno processo da Contra-Reforma. Tendo como um de seus objetivos centrais o de propagar a palavra de Cristo aos pagãos, os jesuítas foram rapidamente levados a outros continentes. Ao tempo da entrada de Sepp na Ordem inaciana, difundia-se pela Europa o ideal e um entusiasmo pelas missões em terras estrangeiras. Segundo a historiadora Eliane Cristina Deckmann Fleck: "A vocação de servir, idealizada por Loyola, foi transformada então na ideia de missão, que passou a moldar indiscutivelmente o pensamento e a prática da Companhia de Jesus."114

Como dissemos acima, entre os anos em que Antônio Sepp cumpria seu interstício, surgiu a oportunidade de enviar ao geral da ordem o pedido para servir como missionário nas Índias. Vários anos se passaram até que o já sacerdote recebesse uma resposta favorável. Na verdade, foi justamente no período em que cumpria seu terciado que recebeu a carta-resposta de seus superiores, concedendo-lhe permissão de ir às missões. Tal possibilidade, no entanto, não se efetivaria de imediato. Sepp embarcaria rumo ao novo continente somente em janeiro de 1691, praticamente dois anos depois. ${ }^{115}$

O período de sete anos de espera muito tem a ver com o processo de seleção daqueles membros que seriam enviados para outros continentes. Porém, mais do que isso, pesava no caso de Sepp o fato de ter origem germânica. Ou seja, uma questão política. As missões de ultramar contavam com o suporte das Coroas Ibéricas, que viam na ação dos jesuítas junto aos "pagãos" de diversas partes do globo uma forma de conquistar novos súditos, estabelecer núcleos de povoação e, consequentemente, assegurar o domínio territorial de suas colônias. Sendo assim, ficava a cargo dos superiores jesuítas da Província espanhola a escolha dos sacerdotes que seriam

\footnotetext{
113 RABUSKE, Arthur S.J.. Pe. Antônio Sepp, SJ - O Gênio das Reduções Guaranis. 3.ed. São Leopoldo: Editora Unisinos, 2003.p. 40.

${ }^{114}$ FLECK, Eliane. Sobre martírios e curas: medicina e edificação nas reduções jesuítico-guaranis. In: Estudos Ibero-Americanos. PUCRS, v.XXXI, n. 1, pp. 35-50, junho de 2005. Disponível em: http://revistaseletronicas.pucrs.br/iberoamericana/ojs/index.php/iberoamericana/article/viewFile/13 24/1029. Acesso em: 15/04/ 2015.

${ }^{115}$ Cf. RABUSKE, op. cit., pp. 35-42.
} 
enviados para missões localizadas em territórios da Coroa de Espanha.

O historiador Wolfgang Hoffmann Harnisch, responsável pela introdução e notas da edição brasileira dos escritos de Sepp, resume bem a questão:

Segundo a legislação colonial espanhola, a entrada para os territórios americanos só era permitida a jesuítas de determinada nacionalidade. E entre os não-espanhóis esta permissão se estendia especialmente aos súditos habsburgueses. De cada vez, cabiam $25 \%$ das levas saídas dos portos espanhóis a súditos da Áustria e Flandres. Era também dada certa porcentagem aos filhos de possessões italianas, sendo Nápoles a mais importante. ${ }^{116}$

Quanto a este fato, Antônio Sepp complementa:

(...) em geral os espanhóis nem distinguem essas nações entre si, mas para eles todos pertencem ao Império Romano e Alemanha. Dizem: Se os Padres, que enviamos para as Índias, procedem da Província Germania Superior é o quanto basta. O essencial é que não sejam franceses, porque só esta nação é que é odiada na Espanha e é excluída do direito de penetrar no território das Províncias espanholas. ${ }^{117}$

Vemos logo que, embora leis espanholas permitissem o envio de missionários de outras nacionalidades a seus domínios coloniais, as autorizações estavam longe de serem comuns. O próprio padre Sepp relata a surpresa de missionários espanhóis com o fato de nunca terem visto, na América, inacianos da mesma procedência ou província que ele:

Todos queriam saber de que Província éramos e por que a nossa Província Germania Superior até aí não mandara nenhum missionário para o meio dos indígenas. Porque aqui sempre houve Padres de todas as Províncias, até da Galo-Bélgica, uns padres meio franceses. Por isso - assim diziam os Padres - parecia até que nossa Santa Província era ou muito orgulhosa ou não considerava devidamente as Índias, ou então entre nós não havia candidatos suficientes. ${ }^{118}$

Segundo o pesquisador e padre jesuíta Francisco Braumann, eram impostos severos exames de seleção, por parte dos superiores da Companhia na Província

\footnotetext{
116 HARNISCH, Wolfgang H. Introdução. In: SEPP, Antônio. Viagem às Missões Jesuíticas e Trabalhos apostólicos [Introdução e notas de Wolfgang Hoffmann Harnisch; tradução de Reymundo Schneider e dos alunos da Companhia de Jesus, em Pareci] São Paulo: Martins, Edusp, 1972. p. XXVII.

${ }^{117}$ SEPP, op. cit., p. 46.

${ }^{118}$ Ibidem. p. 45.
} 
espanhola, a todos os aspirantes a missionários que, não sendo espanhóis, desejassem servir nas missões americanas. Desconfiava-se particularmente dos candidatos de origem germânica, pois se tinha em conta que praticamente todo o norte da Alemanha havia aderido ao protestantismo. ${ }^{119}$ Se lembrarmos que Antônio Sepp ingressou na Companhia de Jesus justamente na Província da Alemanha Superior (ou Germânia Superior), fica evidente a dificuldade envolvida no processo de sua admissão.

Sepp, ao descrever sua viagem rumo ao novo mundo, saindo do porto de Cádiz em janeiro de 1691, afirma que estava acompanhado de mais quarenta e três jesuítas, sendo ele o único tirolês. Lista espanhóis, italianos, neerlandeses (holandeses), sicilianos, sardos, genoveses, milaneses, romanos, boêmios e austríacos. $^{120}$

No afã de superar estes obstáculos e conseguir a liberação para as atividades missionárias, alguns sacerdotes, e mesmo provinciais, recorriam a certos subterfúgios, como fraudes em documentos que atestavam sua origem. É o caso do jesuíta Antônio Böhn. Companheiro de Sepp desde o período do noviciado, tendo inclusive seguido para América no mesmo navio que ele, Böhn era de origem bávara. Como a Baviera não fazia parte dos domínios habsburgos, o jesuíta temia que seu pedido fosse negado. Assim, alterou parte de seu nome e local de procedência no documento enviado ao Conselho Real de Madri.

Abaixo, reproduzimos este fato com as palavras e explicações de Antônio Sepp. O trecho, embora extenso, elucida muito bem os recursos encontrados por seu colega para evitar o indeferimento da solicitação de ida às missões:

Meu caro Padre Antônio Böhm estava muito preocupado que o considerassem como ambergernse [NE: Amberg, cidade do Alto Palatinado, a leste de Nuremberg.] ou como palatinense, e por isso o excluíssem da missão indígena! Para tanto, modificou parte do seu nome, acrescentando-lhe "Adami Bohemi"; portanto, "filho de Adão Böhm", conforme o nome do pai. Segundo, acrescentou ainda Montipolitanus [NE: Montipolitanus quer dizer, portanto: natural de

119 BRAUMANN, Francisco. 3.000 Guaraníes y un Tirolés: Reducciones guaraníticas - Sepp Von Rainegg (1655-1733). Tradução: José Gallinger. Buenos Aires. Editorial Guadalupe. 1981. Título do original alemão: 3000 Indianer und ein Tiroler. Verlag St. Gabriel Steyer Verlag, 1977. p. 27.

${ }^{120}$ Registros apontam que os anos que se sucederam à chegada de Sepp à América foram favoráveis aos estrangeiros. O Padre Ignacio de Frías, que foi reitor do Colégio de Buenos Aires de 1687 a 1691, foi eleito para representar a Província do Paraguai nas Cortes de Madrid, em Roma. Nessa viagem, conseguiu que o papa Inocêncio XII solicitasse ao Rei da Espanha a permissão de que metade dos missionários enviados à América fosse espanhóis, enquanto a outra metade fosse de súditos do Imperador ou italianos. Cf. HOFFMANN, Werner. Introducción. In: SEPP, Antonio. Relación de viaje a las misiones jesuíticas. Buenos Aires: EUDEBA, 1971. pp. 16-17. 
Amberg], modificando depois o nome para Molipolitanus [NE: Molipolitanus, no entanto, significa: cidade dos molhes ou pontes, isto é, Innsbruck]. Um montipolitano de Innsbruck - isto equivale mais ou menos como a um veneziano natural de Munique! Numa informação sobre nomes e locais de procedência dos missionários que de tempos em tempos é enviado ao Conselho Real de Madri, inscreveu-se então o seguinte: Pater Antonius Adami Bohemi Montipolitanus Ratisbonae in Tyroli natus anno etc. [NE: Padre Antônio, filho de Adão Böhn, ambergense - ou montipolitano de Ratisbona no Tirol] Quem quiser rir, que ria! Eu e meu caro Padre Antônio, nós nos ríamos a valer e estávamos de bom ânimo! No assunto propriamente dito, constitui isso um erro, porque o Padre Procurator Indiarum fez o seguinte: Para não precisar citar em separado a pátria com o nome de cada Padre, colocou ele todos os Padres da mesma origem sob o nome da Província correspondente; e como nossos dois nomes estivessem juntos e eu escrevera "natural do Tirol", era claro que o bom Padre Böhm também tinha que ser do Tirol, a saber de Ratisbona, o que explica o que já disse acima. Isto, meu prezado leitor, meus caros Padres e Irmãos, se deu por puro santo zêlo e por amor que tenho para com estes pobres indígenas. ${ }^{121}$

Certamente outros sacerdotes, de diferentes nacionalidades, pertencentes a diversas províncias, buscaram formas de aumentar suas chances neste processo de seleção extremamente concorrido. As correspondências do Arquivo Romano da Companhia de Jesus relativas aos pedidos de envio às Índias, as chamadas Indipetae, somam mais de 24 mil, em um intervalo de 150 anos. ${ }^{122}$

Uma das possíveis explicações para tamanha procura pela vida missionária é que começaram a circular, desde os primeiros anos de presença jesuíta em outros continentes, correspondências de missionários que atuavam junto aos povos longínquos, o que certamente contribuiu para despertar e desenvolver este fervor, especialmente entre os jovens.

\subsubsection{Cartas}

Desde seus primeiros anos, a Companhia de Jesus preocupou-se em normatizar a prática epistolar de seus membros. Como Ordem criada para expandir os limites da fé católica, os jesuítas encontraram nas cartas uma forma de manterem-se

${ }^{121}$ SEPP, Antônio. Viagem às Missões Jesuíticas e Trabalhos apostólicos [Introdução e notas de Wolfgang Hoffmann Harnisch; tradução de Reymundo Schneider e dos alunos da Companhia de Jesus, em Pareci] São Paulo: Martins, Edusp, 1972. pp. 46-47.

${ }^{122}$ Cf. FABRE, Pierre-Antoine; VINCENT, Bernard (dir.). Missions religieuses modernes "notre lieu est le monde". Rome: École française de Rome, 2007. 410p. Collection de l'École française de Rome 376. 
informados do que ocorria em cada local de atuação, aumentando o controle sobre seus membros e buscando evitar possíveis desvios das práticas estabelecidas pelas Constituições.

No caso das missões, tanto as da América quanto as de outras partes do globo, os superiores tinham como dever escrever ao provincial e estes ao Pe. Geral, a cada quatro meses, uma carta com informações sobre o trabalho nas missões. Deveriam ser escritas tanto em sua língua materna como em latim. Tais orientações encontram-se na parte VII das Constituições da Companhia de Jesus, voltada à união dos membros da Ordem com seus superiores e entre si. ${ }^{123}$ Elas deveriam contar fatos edificantes e transmitir informações sobre a vida e a atividade jesuítica local, seus êxitos e dificuldades, para que os demais jesuítas, em outras missões ou nos colégios e igrejas na Europa, soubessem e se consolassem. Assuntos como saúde, problemas pessoais, deveriam constar em outra carta, escrita de acordo com a necessidade e permanecendo sob sigilo. As cartas geralmente eram lidas nos colégios durante as refeições, para a edificação de quem as ouvisse. Em resumo, para os jesuítas, as correspondências informavam e tinham o objetivo de reunir os dispersos em um só coração, não só transmitindo experiências místicas, mas também as provocando. Como afirma João Adolfo Hansen, no caso dos missionários "a função inicial da correspondência como relatório é sobredeterminada no consumo da mesma pela comunidade da Cia., produzindo-se um novo valor de uso, o de uma leitura edificante." ${ }^{\prime 24}$ Dessa forma, a correspondência acaba cumprindo duas grandes funções iniciais: fornecer informações sobre o andamento da ação, tratando tanto de negócios exteriores quanto interiores à Ordem, e propagar e reforçar internamente o controle, a obediência e a piedade da sua "devotio moderna." 125

Antônio Sepp participou desta dinâmica não só pela leitura de correspondências de missionários nos tempos em que ainda era noviço ou já sacerdote atuante nos colégios da Companhia, como também pela escrita de suas próprias experiências junto aos indígenas paraguaios. Assim como seus irmãos de Ordem, Sepp também remeteu diversas cartas a seus provinciais, superiores e também

\footnotetext{
${ }^{123}$ CONSTITUIÇÕES da Companhia de Jesus e Normas Complementares. São Paulo: Edições Loyola, $2004 . \quad$ (1558). pp. 187-204. Disponível em: http://books.google.com.br/books?id=TF3d94YuJYoC\&printsec=frontcover\&hl=pt$\mathrm{BR} \&$ source=gbs_ge_summary_r\&cad=0\#v=onepage\&q\&f=false. Acesso em: 11/05/2015.

${ }^{124}$ HANSEN, João Adolfo. O nu e a Luz: Cartas jesuíticas do Brasil. Nóbrega, 1549-1558. Revista do Instituto de Estudos Brasileiros, n. 38, p. 87-119, 1995. pp. 108-109. Disponível em: http://www.revistas.usp.br/rieb/article/view/71891. Acesso em: 11/05/2015.

125 Ibidem.
} 
familiares que nos permitem analisar sua atuação.

\subsubsection{Os escritos de Sepp}

Ao trabalharmos a primeira fase da vida de Antônio Sepp, utilizamos principalmente estudos biográficos realizados por pesquisadores, em sua maioria da própria Ordem, já que, por estarem localizadas em arquivos europeus e por não terem sido até hoje publicadas em obras em português, as fontes primárias referentes aos anos em que Sepp viveu na Europa não nos foram acessíveis. Porém, ao tratarmos do período em que esteve na América, serão os escritos do próprio missionário que nos servirão de guia. Não abandonaremos, todavia, os trabalhos utilizados até aqui. Adicionaremos a estas pesquisas aquilo que o próprio jesuíta relatou. Faremos aqui um breve resumo destes relatos, antes de passarmos à análise da trajetória americana de Antônio Sepp.

As cartas escritas pelo missionário em 1691 e dirigidas, em grande parte, a seu irmão Gabriel von und zu Rechegg, redigidas tanto em latim, a língua utilizada pela Companhia, como em alemão, sua língua materna, compõem a obra intitulada Viagem às Missões Jesuíticas. Este livro, reunindo parte do material enviado pelo jesuíta a seu irmão, continha na edição inicial apenas cinco cartas, tendo sido editado em 1698. Ao todo, supõe-se que a obra teve quatro edições. ${ }^{126}$

Outra compilação baseada nas cartas do padre Sepp é Trabalhos Apostólicos, sendo que as cartas que a constituem foram escritas por ele em 1701, abrangendo o período de 1693 a 1701 e tendo o livro sido editado pela primeira vez em $1710 .{ }^{127}$ Durante sua edição, foi dividido em capítulos, que não necessariamente correspondem ao conteúdo de cada carta escrita por Sepp, podendo duas ou mais correspondências compor um capítulo ou, ao contrário, uma única carta ter sido desmembrada em vários capítulos. Os nomes dados aos nove capítulos da primeira compilação e aos trinta e cinco da segunda seguem a lógica de pequenos resumos dos acontecimentos e temas que serão descritos na sequência. Como exemplos temos De como estão

126 HARNISCH, Wolfgang H. Introdução. In: SEPP, Antônio. Viagem às Missões Jesuíticas e Trabalhos apostólicos [Introdução e notas de Wolfgang Hoffmann Harnisch; tradução de Reymundo Schneider e dos alunos da Companhia de Jesus, em Pareci] São Paulo: Martins, Edusp, 1972. p. XLVII.

127 Atualmente, ambas as compilações se encontram publicadas, no Brasil, em uma edição de 1972 da Livraria Martins Editora em conjunto com a Editora da Universidade de São Paulo, contendo notas e introdução de Wolfgang Hoffmann Harnisch e com tradução de Reymundo Schneider e dos alunos da Companhia de Jesus em Pareci. 
organizadas as aldeias de índios convertidos; Prodigiosa conversão de Moreyra, aquele mágico, tirano e régulo sexagenário, ou Edificam-se hospitais para acolher os contaminados de ambos os sexos.

Outros dois importantes escritos do padre Antônio Sepp servem de base para este capítulo. O primeiro deles é a carta escrita pelo missionário quando este já contava com mais de 25 anos de atuação entre os indígenas na Província Jesuítica do Paraguai. A Carta latina de 13 de junho de 1714, procedente de São Xavier e endereçada ao Pe. José Preiss, S.J., está publicada na terceira edição da obra $P e$. Antônio Sepp, SJ - O Gênio das Reduções Guaranis, do Pe. Arthur Rabuske SJ (2003), que se encarregou da tradução do documento, baseado na tradução alemã de Johann Mayr (1988). Nos apêndices da segunda edição ampliada do livro de Rabuske, encontramos ainda a relação de instruções escritas pelo próprio padre Sepp na Redução de São José, em 1732, e destinada aos jesuítas recém-chegados às missões. Algumas instruções relativas ao governo temporal das reduções em suas fábricas, sementeiras, estâncias e outras fainas nos permite um olhar mais aprofundado sobre os métodos de trabalho dos missionários e a vida econômica das reduções. A tradução vernácula deste documento data de 1958, de autoria do padre Pedro Inácio Schmitz, S.J.

As cartas de Antônio Sepp contém narrativas riquíssimas e que, baseadas nos preceitos epistolares da Companhia de Jesus, referem-se predominantemente ao cotidiano de trabalho. É necessário, porém, atenção. Suas correspondências não buscavam apenas informar ou edificar, como muitas vezes quer nos fazer crer o jesuíta. Eram relatos estruturados de forma a criar determinada imagem do padre missionário. E isso é perceptível na riqueza de detalhes com que descreve situações e atividades nas quais se destaca, como as artimanhas realizadas para a conversão de um "afamado" feiticeiro, seus esforços e sucessos no ensino musical dos indígenas ou a fundação de uma nova redução. Certamente pensava em como seria lido, interpretado e lembrado, tanto por seus irmãos de Ordem quanto pelo público leigo. Algo a se esperar em um homem que durante anos foi professor de Retórica, que dominava plenamente a utilização das cartas e estava imbuído dos preceitos e normas inacianas. 
Embora Antônio Sepp tenha recebido a permissão para ir às missões em 1687, em resposta à solicitação feita cinco anos antes, só recebeu seu certificado de missionário paraguaio, assinado pelo provincial alemão, em 1689. Neste ano tem início, de forma inesperada, sua jornada rumo ao novo mundo. Viagem que ainda levaria dois anos para se concretizar.

Segundo Mayr, o já citado Pe. Antônio Böhm teve, em 1689, outro contratempo: o missionário destinado a acompanhá-lo às missões americanas adoeceu, o que obrigou o Geral da Ordem, Tirso González (1624-1705), a buscar um substituto. Acionando o provincial alemão, González solicitou que se apressasse o envio de Antônio Sepp, então em Altötting realizando seu terciado, com fins de substituir o companheiro adoecido. ${ }^{128}$ Seu destino era Gênova, ponto de partida dos missionários rumo ao reino de Espanha, de onde navegariam com destino à América saindo do porto de Cadiz. Neste roteiro, Sepp passaria ainda por cidades como Trento, Gibraltar e Sevilha.

O vilarejo de Altötting, localizado próximo da fronteira bávaro-austríaca, era importante local de peregrinação graças à considerada milagrosa Virgem Negra de Altötting. ${ }^{129}$ Como Sepp era um fervoroso devoto da santa, recebeu dos cônegos locais uma lasca da imagem original, para que fosse levada ao novo mundo e lá despertasse a devoção de muitos. Com esta relíquia e mais alguns objetos pessoais, Antônio Sepp dirigiu-se a sua terra natal para despedir-se de familiares e então, de Trento, rumou para Gênova. Neste percurso, como o próprio missionário nos informa, passou por alguns apuros: "Vindo de Trieste, cheguei a 9 de julho de 1689 a Gênova, depois de haver escapado de dois grandes perigos, a saber do saque das coisas do meu uso e dum atentado assassino contra a minha vida." ${ }^{130}$ E continua: "De Gênova viajei pelo Mar Mediterrâneo através de um naufrágio iminente e entrei felizmente em

${ }^{128}$ MAYR apud RABUSKe, Arthur S.J. Pe. Antônio Sepp, SJ - O Gênio das Reduções Guaranis. 3.ed. São Leopoldo: Editora Unisinos, 2003. p. 104.

129 “Altötting é pequena localidade na fronteira bávaro-austríaca, onde se encontra uma imagem de Nossa Senhora, de 1300, toda denegrida pelo tempo. Não quiseram restaurá-la nem tocá-la, tornando-se por isso a chamada 'Virgem Negra de Altötting'. A vila constitui lugar de peregrinação, motivo por que é chamada 'Loreto alemã'." HARNISCH, Wolfgang H. Nota 1. In: SEPP, Antônio. Viagem às Missões Jesuíticas e Trabalhos apostólicos [Introdução e notas de Wolfgang Hoffmann Harnisch; tradução de Reymundo Schneider e dos alunos da Companhia de Jesus, em Pareci] São Paulo: Martins, Edusp, 1972. p. XXIII.

${ }^{130}$ Ibidem, p. 10. 
Cádiz aos 11 de setembro (...).”131

Após chegar em Sevilha de Andaluzia, Antônio Sepp se juntou a seu amigo e companheiro Antônio Böhm e a diversos outros jesuítas que aguardavam a oportunidade de realizar a travessia do Atlântico. Esta espera levaria mais de um ano.

Enquanto aguardavam a chance de viajarem, os jesuítas aproveitavam o tempo para complementar sua formação. Segundo Braumann: "Con tal fin, los Padres ya en Sevilla aprendían a sembrar y cosechar maíz, cebada, mandioca y yerba. También debían conocer de que módo secar, trillar y moler los granos." ${ }^{132}$ Sepp, neste período, ainda buscou aprender o castelhano e se voltou ao aprendizado inicial da língua guarani.

Além disso, dedicou-se, com o auxílio de outros inacianos, à produção de centenas de cópias de barro da imagem de Nossa Senhora de Altötting, para que pudesse distribuí-las no novo continente, o que auxiliaria no processo de conversão e catequese. A historiadora Jacqueline Ahlert, ao estudar as representações imagéticas nas missões da Província Jesuítica do Paraguai, afirma que poucos eram os missionários especializados em artes plásticas, sendo que a maioria consistia em "padres dedicados e estudiosos, formados pela pressão das circunstâncias. Parte deles passou por uma prévia preparatória de dois anos em Sevilha, deixando registrada na escultura da América colonial a influência desta Escola (...). ${ }^{133}$

Finalmente, em 17 de janeiro de 1691, parte a frota de três navios que transportariam Antônio Sepp e mais 43 missionários jesuítas do porto de Cádiz rumo a Buenos Aires. Conforme relata Sepp: "Eram três grandes navios de guerra e bem providos de toda espécie de munição de guerra. Todos levavam 50 a 60, sim, até mais peças de guerra."134 Os navios, Capitânea, Almiranta e Pinque, eram todos capitaneados e tripulados por espanhóis. Antônio Sepp e os jesuítas seguiram no Almiranta, junto com:

131 SEPP, Antônio. Viagem às Missões Jesuíticas e Trabalhos apostólicos [Introdução e notas de Wolfgang Hoffmann Harnisch; tradução de Reymundo Schneider e dos alunos da Companhia de Jesus, em Pareci] São Paulo: Martins, Edusp, 1972. p. 10

132 BRAUMANN, Francisco. 3.000 Guaraníes y un Tirolés: Reducciones guaraníticas - Sepp Von Rainegg (1655-1733). Tradução: José Gallinger. Buenos Aires. Editorial Guadalupe. 1981. Título do original alemão: 3000 Indianer und ein Tiroler. Verlag St. Gabriel Steyer Verlag, 1977. p. 34.

133 AHLERT, Jacqueline. Amálgamas culturais e representações imagéticas nas doutrinas da Província Jesuítica do Paraguai. In: Sæculum - Revista de História [28]; João Pessoa, jan./jun. 2013. pp. 6781. Disponível em: http://periodicos.ufpb.br/ojs/index.php/srh/article/view/18189. Acesso em: 10/04/2015.

${ }^{134}$ SEPP, op. cit., p. 11. 
os senhores governadores de Buenos Aires, Assunção e Chile, além da senhora governadora e seus filhos. Vinham conosco ainda diversos negociantes, caixeiros, barbeiros, escravos pretos ou negros, negras, duzentos soldados, cem marinheiros e toda espécie de gente vil, trapalhões e gentalha. ${ }^{135}$

\subsubsection{Travessia oceânica e primeiras impressões da América}

Os relatos acerca das condições precárias que marcavam as travessias marítimas desde o século XVI são abundantes. Problemas relacionados com a comida a bordo, as instalações dos navios, a instabilidade do tempo em alto mar e a vida cotidiana dessas viagens é tema trabalhado em inúmeros trabalhos historiográficos. Segundo o historiador Paulo Miceli, as condições de isolamento durante as longas travessias faziam com que a escassez de suprimentos fosse regra para a quase totalidade dos viajantes:

Quando a viagem transcorria sem incidentes, a comida mal bastava para as necessidades dos embarcados, mas, se um longo período de calmaria, a imperícia do piloto ou qualquer outra ocorrência provocassem o alongamento da viagem, a fome atingia o navio de modo implacável. ${ }^{136}$

Antônio Sepp não deixa de descrever em seu Viagem às missões jesuíticas a rotina desta temível travessia. Conta que, devido ao mar turbulento, tinham que manter fechadas as pequenas janelas da embarcação, o que alastrava um odor nauseabundo por todo o navio. Além disso, havia ratos por toda parte. Quanto às condições das cabines ocupadas pelos missionários, descreve: “O lugar que o capitão indicou para um padre era tão pequeno que aí não se podia nem ficar parado, nem caminhar. Sim, mal dava para se deitar. Media dois pés de largura e cinco pés de comprimento." 137

Não obstante a alimentação deficiente, a falta de água potável, que chegou a ser racionada, e apesar dos "calores" que molestavam todos os embarcados, houve apenas uma baixa entre todas as embarcações. E durante a viagem, o padre Sepp encontrou na música uma forma de amenizar as condições hostis e entreter seus

135 SEPP, Antônio. Viagem às Missões Jesuíticas e Trabalhos apostólicos [Introdução e notas de Wolfgang Hoffmann Harnisch; tradução de Reymundo Schneider e dos alunos da Companhia de Jesus, em Pareci] São Paulo: Martins, Edusp, 1972. p. 11

${ }^{136}$ MICELI, Paulo. O ponto onde estamos: viagens e viajantes na história da expansão e da conquista (Portugal, século XV e XVI). 4. ed. - Campinas, SP: Editora da Unicamp, 2008. p. 138.

${ }^{137}$ SEPP, op. cit., p. 11. 
companheiros:

Para que os pobres missionários se pudessem alegrar no Senhor, toquei, à mesa, com minha tiorba. ${ }^{138}$ Mais tarde, o Pe. Antônio e eu tocamos na flauta algumas cançonetinhas pastorais e cantamos também aquele cântico consolador de São Paulo (...). ${ }^{139}$

Além disso, fez questão de atrair a simpatia dos governadores a bordo, dando aulas de música para alguns de seus negros escravos:

Hoje dei lição de música aos meus quatro trombetas negros. Já que não conheciam as notas, tive que tocar e cantar primeiro as peças, até que entrassem nas cabeças duras, o que requeria muita paciência. Finalmente, aprenderam seis ou sete pecinhas, com grande satisfação dos senhores governadores, aos quais pertenciam estes escravos. Mais tarde, em Buenos Aires, esses senhores me agradeceram muito gentilmente. ${ }^{140}$

Segundo os relatos do missionário, foi nesta rotina de ensino musical aos escravos e da doutrina cristã "às mães negras e seus filhos", que transcorreram os dois meses e meio de viagem. Miceli também aponta o importante papel dos religiosos a bordo, cujas vozes "levantavam-se em ladainhas e orações, e as procissões solenes percorriam o convés, na tentativa de combater as dores e dificuldades que alimentavam o medo coletivo." ${ }^{141}$ O próprio Sepp relata diversas missas que rezou a bordo da Almiranta e descreve celebrações religiosas em dias de santos como São Francisco Xavier.

Após ter enfrentado tormentas e calmarias, a frota chegou a Buenos Aires em uma sexta-feira santa, no dia 6 de abril de 1691. Antônio Sepp, extremamente aliviado pelo fim da travessia, surpreende-se com a pequena cidade que encontra. A seu juízo, não passava de uma pequena aldeia situada sobre a margem ocidental do impressionante Rio da Prata. Com algumas poucas casas "de barro e lama", Buenos Aires resumia-se a duas ruas, abertas em encruzilhada. Sobre a organização da

138 "A tiorba, surgida também nesse século [XVII], é uma variante ampliada do alaúde, com duas cravelheiras e possuindo entre vinte e vinte e cinco cordas. Usada até meados do séc. XVIII." PREISS, Jorge Hirt. A música nas missões jesuíticas nos séculos XVII e XVIII. Porto Alegre: Martins Livreiro Editor, 1988. p. 65.

${ }^{139}$ SEPP, Antônio. Viagem às Missões Jesuíticas e Trabalhos apostólicos [Introdução e notas de Wolfgang Hoffmann Harnisch; tradução de Reymundo Schneider e dos alunos da Companhia de Jesus, em Pareci] São Paulo: Martins, Edusp, 1972. p. 21.

${ }^{140}$ Ibidem, p. 27.

${ }^{141}$ MICELI, Paulo. O ponto onde estamos: viagens e viajantes na história da expansão e da conquista (Portugal, século XV e XVI). 4. ed. - Campinas, SP: Editora da Unicamp, 2008. p. 156. 
pequena cidade, descreve que: "está nas mãos dum prefeito da coroa espanhola. Em cada cinco anos é mandado da Espanha um novo senhor, que assume o governo." 142

E era exatamente neste contexto que os navios vindos da Europa aportavam na modesta, porém estrategicamente importante, povoação. A frota trazia Agustín de Robles Lorenzana, nomeado pelo rei Carlos II de Espanha para assumir a Gobernación del Rio de La Plata, território que fazia parte do Vice-Reino do Peru. Contradizendo a afirmação de Sepp, Lorenzana permaneceria como governador até 1700, tendo como principal atribuição incrementar as defesas da cidade contra possíveis ataques dos portugueses, franceses e indígenas belicosos. ${ }^{143} \mathrm{E}$ como a Companhia de Jesus era peça-chave para assegurar o controle territorial dos domínios coloniais espanhóis, o governador poderia contar, para a defesa da cidade e arredores, com a ajuda providencial dos jesuítas e seu exército de indígenas reduzidos:

Para a defesa da cidade e de todo este grande país não há mais do que novecentos soldados espanhóis. Mas se surgisse algum perigo, poríamos imediatamente a caminho mais de trinta mil índios de nossas reduções, aliás todos a cavalo, e estes sabem muito bem lidar com mosquetões e manejar a espada, bem como atacar em formação de meia-lua, vindo dos flancos de batalha, formar esquadrões, lutar na ofensiva e defensiva, e isto tão bem quanto qualquer europeu. Além disso foram exclusivamente instruídos pelos Padres. ${ }^{144}$

Como se tratava da chegada de um enviado de sua Majestade, é evidente que a população local se mobilizou para recepcionar os viajantes com as devidas honrarias. Estas manifestações marcadas por sonoridades, certamente singelas pelo contexto do povoamento, não escaparam ao registro do jesuíta Antônio Sepp:

Esta manhã não se ouvia sobre o Rio da Prata outra coisa senão o trovejar alegre dos canhões metálicos, o som marcial das trombetas, o murmurar dos tambores e pífanos, o vozerio faceiro dos

${ }^{142}$ SEPP, Antônio. Viagem às Missões Jesuíticas e Trabalhos apostólicos [Introdução e notas de Wolfgang Hoffmann Harnisch; tradução de Reymundo Schneider e dos alunos da Companhia de Jesus, em Pareci] São Paulo: Martins, Edusp, 1972. p. 41.

${ }^{143}$ PAYRÓ, Roberto P. El Río de la Plata: de colonias a naciones independientes: De Solís a Rosas (1516-1852). Buenos Aires: Alianza Editorial. 2006. Este livro está disponível na internet em dois tomos, porém com outro título: Historia del Río de la Plata. A parte à qual nos referimos encontra-se no tomo I. pp. 73-74. Disponível em: https://rppayro.files.wordpress.com/2008/10/historia-del-rio-de-la-plata_tomo-i.pdf. Acesso em: 10/04/2015.

${ }^{144}$ SEPP, op. cit., p. 42. 
marinheiros e pescadores. ${ }^{145}$

Mais representativo ainda é notarmos que a primeira referência aos indígenas americanos feita pelo missionário ao chegar ao novo mundo revela a presença de práticas musicais. Ao descrever os tipos que os aguardavam, diz: "Na margem, via-se algumas companhias de guardas espanholas a cavalo e a pé, bem como incontáveis americanos com seus instrumentos musicais." 146 Após o desembarque e já em companhia do Padre Provincial Gregório de Orosco, além de todos os padres do colégio e de uma "multidão de nativos", os inacianos recém-chegados ainda assistiram a uma apresentação do Te Deum Laudamus ${ }^{147}$, "que os índios não cantaram mal". ${ }^{148}$ Estes apontamentos explicitam o fato de, ao tempo da chegada de Antônio Sepp à América, o ensino da música aos neófitos já ser prática corrente dos missionários jesuítas. Sepp traria modificações importantes na forma de ensinar e executar a música, como veremos adiante, mas não coube a ele a primazia no ensino musical, conforme podemos verificar em suas cartas, em documentos de época e em diversas pesquisas apresentadas no capítulo anterior. ${ }^{149}$

Mas voltando à recepção da frota pelos colonos, a vinda das embarcações certamente animava a reduzida população não tanto pela chegada de um novo administrador quanto pela possibilidade de abastecimento do mercado local. Como as viagens ao novo mundo eram realizadas com um intervalo de anos entre uma e outra, os colonos, incluam-se aí as ordens religiosas atuantes na América, sofriam com a escassez de produtos europeus. Vale lembrar que na frota em que estava Antônio Sepp não vieram somente autoridades coloniais, marujos e religiosos, mas também diversos comerciantes que viam na carência da colônia um rentável negócio:

Já andava pelo terceiro ano que esperavam pela chegada desses três navios. Os bons moradores desta cidade (ela não é maior do que

145 SEPP, Antônio. Viagem às Missões Jesuíticas e Trabalhos apostólicos [Introdução e notas de Wolfgang Hoffmann Harnisch; tradução de Reymundo Schneider e dos alunos da Companhia de Jesus, em Pareci] São Paulo: Martins, Edusp, 1972. p. 39.

146 Ibidem.

147 "Te Deum [Lat.]. A song of praise to God sung in the Romam rite at the end of Matins on Sundays and feast days, in the Middle Ages following the last responsory, in modern practice replacing it. As a 'Hymn of Thanksgiving', it has also long been sung at both religious and secular ceremonies such as coronations and celebrations of victory in battle." RAENDEL, Don Michael. The Harvard Dictionary of Music. 4th ed. Cambridge, Massachusetts and London, England. The Belknap Press of Harvard University Press. 2003 (1986). p. 871.

${ }^{148}$ SEPP, op. cit., p. 39.

${ }^{149}$ Como exemplo, Ver: PREISS, Jorge Hirt. A música nas missões jesuíticas nos séculos XVII e XVIII. Porto Alegre: Martins Livreiro Editor, 1988. pp. 19-28. 
uma aldeia) e das granjas covizinhas haviam caído em extrema pobreza e mal tinham ainda uma camisa com que vestir-se. (...) Nossos navios estavam carregados com, pelo menos, doze milhões de toda espécie de mercadorias, como ferro, cobre, linho e, até, madeira. ${ }^{150}$

O missionário explicita ainda mais esta carência latente ao relatar a coexistência de diversas ordens religiosas em Buenos Aires. Em comum entre elas estava a falta de produtos essenciais às suas atividades:

Os quatro conventos de ordem religiosa que há aqui pertencem aos Franciscanos, Dominicanos, Trinitários e à Companhia de Jesus. Vivem todos em extrema pobreza e privação, porque a carestia aqui é extraordinariamente grande. ${ }^{151}$

Como recomendação do provincial, os jesuítas recém-chegados deveriam repousar por um mês no colégio da Ordem. Era uma medida de precaução, visando o restabelecimento físico dos missionários após a longa e extenuante viagem. Durante este intervalo, no qual aguardava a decisão sobre para qual redução seria enviado, Antônio Sepp pode observar melhor a cidade, os nativos, os hábitos e a rotina local. Logo atestou que o idioma de maior importância local era o guarani e travou contato com alguns indígenas reduzidos, constatando que "os paraguaios" eram cristãos muito bons e piedosos. Obedientes e amáveis aos padres jesuítas, possuíam ainda uma qualidade que seria fundamental para as práticas musicais que levaria a cabo futuramente: o fato de que estes nativos "imitam tudo que veem."152

O missionário também teve tempo para conhecer e conversar com jesuítas que já atuavam há vários anos em terras paraguaias. Afirma que ele e o padre Antônio Böhm eram os que mais recebiam visitas no Colégio da Companhia, já que todos tinham curiosidade em conhecer missionários alemães, tão raros nestas paragens, conforme explicamos anteriormente. A muitos destes visitantes, o jesuíta ofereceu pequenos presentes trazidos da Europa, além de algumas imagens de argila que produziu em seus dias de espera em Sevilha. Segundo Sepp, os regalos foram recebidos com grande alegria justamente pela falta de produtos enfrentada pelos religiosos, que muitas vezes não conseguiam arcar com os altos preços cobrados por

\footnotetext{
${ }^{150}$ SEPP, Antônio. Viagem às Missões Jesuíticas e Trabalhos apostólicos [Introdução e notas de Wolfgang Hoffmann Harnisch; tradução de Reymundo Schneider e dos alunos da Companhia de Jesus, em Pareci] São Paulo: Martins, Edusp, 1972. p. 5.

${ }^{151}$ Ibidem, p. 41.

${ }^{152}$ Ibidem, p. 9.
} 
mercadorias vindas de fora e não encontradas nestas paragens:

Tudo foi recebido com o máximo reconhecimento, como se fora ouro e prata. Uma imagem, que por causa de sua péssima qualidade chamaríamos 'droga', pode muito bem ser, com todas as honras, oferecida aqui a um Padre Reitor ou a um Provincial; ele por isso não será menos reconhecido como alguém na Europa, a quem se oferecesse a mais encantadora miniatura. Isto só se explica pelo fato de aqui haver a máxima carência desses objetos. ${ }^{153}$

Nota-se que não só utensílios e ferramentas faziam falta aos missionários. Esculturas ou partituras, por exemplo, usadas seja com fins pedagógicos e doutrinários seja como exemplos para a produção nas oficinas, também eram escassas e seus preços exorbitantes. Vendo a situação em que se encontravam seus irmãos de Ordem, podemos supor que o Padre Sepp enxergasse nas cartas enviadas à Europa uma das únicas possibilidades de apelar auxílio a seus superiores, mestres e conhecidos, solicitando itens que lhe eram caros, principalmente para o ensino musical dos neófitos. $\mathrm{O}$ trecho que reproduziremos abaixo apresenta um panorama de como, materialmente, alguns pedidos poderiam ser atendidos, amenizando a escassez enfrentada pelos missionários paraguaios. Ao solicitar partituras a seus colegas europeus, Sepp escreve:

Tende piedade, por amor ao Cristo, de meus milhares de pobres músicos e mandai-me as Missas, as Vesperas breves, breviores e brevíssimas, bem como as Ladainhas do senhor Melchior Glettle, mestre-capela da catedral de Augsburgo. Não tenho coragem de solicitar os motetes, mas, se apesar disso vierem, seria como se um anjo do céu os trouxesse para o Paraguai. Mas vós logo respondereis: Meu caro Padre Antônio, do fundo do coração folgamos em te enviar tudo, mas quem no-las pagará? Primeiramente eu me comprometo, e comigo mais seis Padres missionários, de rezarmos seis Santas Missas na intenção daquele, seja religioso ou leigo, que queira arcar com as despesas. Pelo Padre, porém, que mas enviar, nós queremos rezar vinte Missas, pelos seus esforços. Depois não pretendo que sejam novas. Sejam tão velhas, rasgadas e sujas como queiram, desde que sejam legíveis, porque os músicos indígenas já escrevem bem as notas (...) E se alguém perguntar para onde mandar o pacote, para que chegue ao Paraguai, respondo-lhe: Se estiver em Gênova ou Roma, então já está no Paraguai, indiferente se demora um pouco mais ou menos. O melhor seria entregar a encomenda ao Padre Procurador em Roma. Esse a passará ao Procurador do Paraguai, que agora é enviado para

153 SEPP, Antônio. Viagem às Missões Jesuíticas e Trabalhos apostólicos [Introdução e notas de Wolfgang Hoffmann Harnisch; tradução de Reymundo Schneider e dos alunos da Companhia de Jesus, em Pareci] São Paulo: Martins, Edusp, 1972. p. 45. 
Roma. E caso não estiver aí nenhum Procurador, então ao Procurador das Duas Índias, que se mantém ininterruptamente em Roma. (...) Com o pagamento, digo, é bem fácil. A saber, do modo seguinte: A Província daqui restitui tudo ao Padre Procurador de Munique, indistintamente se ele gasta muito ou pouco por um Padre. Tivesse eu sabido disto, quando ainda me achava em minha Província, e tivesse eu também sabido quais as coisas que muito se precisam e insistentemente se solicitam no Paraguai, teria eu logo em Munique comprado muitas coisas para o Paraguai e as levado comigo, e com isto por certo teria prestado a esta Província e a todos os Missionários um grande obséquio. ${ }^{154}$

Ao comprometer-se em rezar muitas missas em nome daqueles que atenderem a seu pedido, Sepp parece deixar clara a incapacidade de arcar com os custos de tal encomenda, compensando tais despesas com benefícios "espirituais". Interessante notar que o missionário se compromete a rezar missas tanto para religiosos quanto para leigos, o que nos permite supor que o jesuíta sabia que sua correspondência poderia atingir leitores externos à Companhia ou que, em último caso, seus irmãos de Ordem poderiam apelar para o auxílio de financiadores leigos.

Ao explicar o procedimento pelo qual seu pedido poderia ser atendido, o missionário nos deixa entrever as dinâmicas que envolviam as solicitações de jesuítas em missão pelo mundo. A referência às formas de pagamento é extremamente interessante por permitir algumas suposições. Antônio Sepp explica que a Província do Paraguai restituía aos padres procuradores europeus os gastos efetuados para suprir suas demandas. Afirma ainda que se soubesse disso antes de vir à América, teria comprado muitas coisas das quais agora sentia necessidade. Essa evidência aponta para um desconhecimento de um membro da Companhia no que se refere às normas e procedimentos práticos da mesma. De forma mais clara, indica uma certa confusão burocrática, possível devido às divisões administrativas entre províncias, com maior ou menor alinhamento a Roma, seja por questões políticas, seja pelas dificuldades impostas pela distância.

Quanto ao desconhecimento das coisas "que muito se precisam e insistentemente se solicitam no Paraguai", é evidente que em seu tempo de preparação para vir às missões o jesuíta tenha entrado em contato com diversas cartas de missionários atuantes em terras paraguaias, assim como em outros pontos do globo. No entanto, estas eram cartas edificantes, de divulgação relativamente grande dentro

\footnotetext{
154 SEPP, Antônio. Viagem às Missões Jesuíticas e Trabalhos apostólicos [Introdução e notas de Wolfgang Hoffmann Harnisch; tradução de Reymundo Schneider e dos alunos da Companhia de Jesus, em Pareci] São Paulo: Martins, Edusp, 1972. pp. 74-75.
} 
da Ordem e cujo objetivo central era comover, reunindo os dispersos em um só coração. Questões pessoais, solicitações e outros assuntos internos, que poderiam revelar necessidades como as que Sepp encontrou em sua chegada, deveriam seguir em outras correspondências, as hijuelas, de acesso mais restrito e em geral endereçadas a superiores e Provinciais. ${ }^{155}$

De qualquer forma, o padre Sepp constatou a carência de mercadorias logo que chegou a Buenos Aires. E dentre todos os produtos cuja falta afetava diretamente o trabalho de colonos e religiosos, talvez o mais primordial fosse o ferro, material necessário em praticamente todas as atividades desenvolvidas pelos jesuítas em suas reduções.

\subsubsection{A falta de ferro}

A carência deste minério na Província Jesuítica do Paraguai já havia sido relatada por diversos membros da administração colonial, além, é claro, dos próprios inacianos. ${ }^{156}$ Jazidas de minério de ferro não haviam sido encontradas neste território, o que fazia com que o preço deste material fosse extremamente alto. Sepp afirma que "nesta terra a prata vale muito menos que o ferro"157 já que o primeiro podia ser encontrado em abundância na América, enquanto o último precisava ser trazido da Europa em viagens que ocorriam esporadicamente, como vimos acima. O jesuíta dá vários exemplos de utensílios de ferro, ou mesmo de latão, que adquiriam enorme valor comercial: "Por um canivete (...) pode-se obter dois lindos cavalos, por uma agulha ou uma brocha troca-se um enorme touro."158

Antônio Sepp relatará em vários momentos de sua vida como missionário paraguaio as enormes dificuldades e limitações advindas da falta de ferro para a produção de utensílios básicos na lida cotidiana. E não só enxadas e facões aparecem relacionados como itens necessários, porém de difícil produção. A confecção de instrumentos musicais também era afetada pela carência do metal. O padre chega até

155 Para mais, Ver: EISENBERG, José. As missões jesuíticas e o pensamento político moderno: encontros culturais, aventuras teóricas. Belo Horizonte: Ed. UFMG, 2000. pp. 53-58.

156 Cf. Testimonio De Pedido Del Padre Anselmo De La Mata De Despacho De Hierro A Las Reducciones De Indios De La Compañía De Jesús. A Continuación, Confirmación Del Despacho Solicitado. 12/04/1691. AR-AGN.DE/CJ. Fondo Jesuíta Digital. Sala IX. División Colonia.

${ }^{157}$ SEPP, Antônio. Viagem às Missões Jesuíticas e Trabalhos apostólicos [Introdução e notas de Wolfgang Hoffmann Harnisch; tradução de Reymundo Schneider e dos alunos da Companhia de Jesus, em Pareci] São Paulo: Martins, Edusp, 1972. p. 42.

${ }^{158}$ Ibidem. 
a descrever a confecção de um órgão para a redução de Yapeyú, na qual se utilizou de tábuas de cedro já que o ferro disponível era insuficiente:

E assim vendo que a miséria dos órgãos usados até então entre os índios não provinha tanto da falta de recursos como de seu estado miserável, deu-me o R. Pe. Provincial, Pe. Lauro Nuñez, ordem de fazer um órgão, como os da Europa, ou de mandar fazê-lo, reservando-me a superintendência da obra. (...) Como, porém, a quantidade de estanho e chumbo arranjada (...) só bastasse para fazer os tubos menores, cuidei que os maiores, do chamado subbaixo, se fizessem de tábuas de cedro desbastadas (...). ${ }^{159}$

Dada a situação encontrada, não é de se admirar que Antônio Sepp tenha relatado com tamanho júbilo que, durante o processo de fundação da missão de São João Batista, realizou uma imensa descoberta: a forma de extrair minério de ferro de um tipo específico de rocha, encontrado em abundância na região:

Com efeito, descobrimos uma pedra sem dúvida mais estimável e preciosa que qualquer tesouro; esta pedra, pelo calor do sol, fica tão dura que não se derrete senão com um fogo muito intenso; e quando mais apurada e endurecida, o que se obtém derramando água aos poucos em cima dela, condensa-se em aço e ferro. (...) Jaz ela no campo, exposta às chuvas e ao sol, ou se apresenta ao primeiro golpe de martelo de baixo da verde grama. ${ }^{160}$

Podemos imaginar com que furor a notícia se espalhou pela Província Jesuítica do Paraguai. Tal descoberta garantia aos jesuítas independência quanto à necessidade de inúmeros produtos vindos da Europa, já que passariam a ser produzidos pelos próprios indígenas nas reduções. Os excedentes poderiam ser comercializados juntos aos colonos, garantindo um lucro considerável. Além disso, o próprio trabalho agrícola e artesanal nas missões sofreria profundas mudanças com a utilização de ferramentas que garantiriam um aumento da produção. Sabendo disso, Sepp afirma: "Se até agora os benignos céus nenhum outro benefício fizeram a estes pobrezinhos, este só bastaria para ser escrito no livro da eternidade: o de lhe terem concedido ferro e aço."161

Fornos foram erguidos e o processo de obtenção e moldagem do ferro foi

\footnotetext{
159 SEPP, Antônio. Viagem às Missões Jesuíticas e Trabalhos apostólicos [Introdução e notas de Wolfgang Hoffmann Harnisch; tradução de Reymundo Schneider e dos alunos da Companhia de Jesus, em Pareci] São Paulo: Martins, Edusp, 1972. pp. 117-18.

${ }^{160}$ Ibidem, p. 164.

${ }^{161}$ Ibidem, p. 166.
} 
ensinado a indígenas que logo se tornaram ferreiros habilidosos. Segundo o missionário, o aço que passou a produzir nos fornos de São João Batista era superior até mesmo ao de Milão. Porém, embora algumas obras biográficas considerem esta descoberta um dos maiores feitos do Padre Antônio Sepp, o impacto real deste acontecimento foi restrito, se pensarmos o tamanho que poderia tomar. E isto porque, ao que tudo indica, o missionário exagerou ao relatar as facilidades da produção deste material e, principalmente, as qualidades do ferro e aço obtidos.

Segundo Furlong, a descoberta ocorrida por volta de 1700 não garantiu nem o abastecimento de ferro das próprias reduções. Analisando o período que vai desde essa data até o ano de 1767, às vésperas da expulsão da Companhia de Jesus do continente, constatou que a importação de ferro da Europa manteve níveis muito parecidos com os anos anteriores ao achado do missionário. ${ }^{162}$ Para reforçar, apresentou em seu livro um informe de 1749 do Padre Cura de São Miguel ao Vicerei do Rio da Prata:

(...) cuando no venía el fierro que pedían al Padre Procurador de Misiones, de esta capital [de Buenos Aires], porque del todo no parasen las faenas y labranzas por falta de herramientas, alguna vez se había hecho algún poco de fierro: pero que, considerado el trabajo, les salía más caro que el comprado, y que nunca era tan bueno como el de Vizcaya. ${ }^{163}$

Se levarmos em conta o excerto, é possível considerar que embora Antônio Sepp tenha descoberto minério de ferro e desenvolvido formas de extraí-lo das rochas e de produzir o tão necessário metal, o acontecimento não produziu os resultados esperados pelo missionário. O processo de fundição surgido em São João Batista teria servido, então, para suprir necessidades mais extremas ou pontuais. Não deve, no entanto, ser considerado como sem relevância. Como nos diz Furlong, é necessário apenas estar atento ao "otimismo exacerbado" do Padre Sepp.

Mas se a carência de metal era latente, outros produtos abundavam e as atividades que os envolviam tornaram-se grande fonte de renda dos inacianos na Província Jesuítica do Paraguai. Entre elas destacam-se a produção de erva-mate e a criação de gado vacum, tendo esta última sido descrita por Antônio Sepp em várias passagens de suas cartas.

\footnotetext{
162 FURLONG, Guillermo S.J. Antonio Sepp y su "gobierno temporal" (1732). Buenos Aires: Ediciones Theoria, 1962. p. 71.

${ }^{163}$ HERNÁNDEZ apud FURLONG, op. cit. p. 73.
} 


\subsubsection{Criação de gado}

Após ter permanecido em Buenos Aires por algumas semanas, período estipulado pelo padre provincial para que os missionários vindos da Europa se restabelecessem, Antônio Sepp e os outros padres estrangeiros foram enviados às missões indígenas. Seguindo rio Uruguai acima, em canoas remadas por índios enviados das reduções, seguiram para aquela cuja localização estava mais próxima de Buenos Aires: a missão de Yapeyú. ${ }^{164}$ A viagem durou um mês, incluindo uma passagem pela grande queda d'água do rio Uruguai. Neste percurso, Sepp pode observar a exuberância da natureza local e travar contato com os temíveis índios Yaros, "bárbaros selvagens" que resistiriam bastante à conversão e que dariam muito trabalho a ele e a outros missionários. ${ }^{165}$

Ao chegarem a seu destino, no dia $1^{\text {o }}$ de junho de 1691, os jesuítas foram recebidos com festa pelos indígenas reduzidos. A recepção, organizada pelo padre responsável pela redução e pelo Padre Superior da Província, contou com danças, demonstrações de cavalaria e infantaria, discursos de boas-vindas do corregedor, "é assim que chamam em espanhol o mais distinto dos indígenas"166, e, como era de se esperar, muita música:

Entrementes, desembarcamos de nossas choças de palha verdejantes, saudamo-nos, abraçamo-nos e seguimos, então, sob o repicar alegre dos sinos, por baixo de lindos arcos de triunfo de grande altura, em direção à igreja, acompanhados de alguns milhares de índios batizados (...). Então os músicos entoaram o Laudate Dominum omnes gentes, e o "Louvai ao Senhor todos os povos" foi cantado em reconhecimento devido ao Supremo Deus, por se haver, mais uma vez, compadecido destes pobres povos, enviando tantos curas de almas e trabalhadores por um caminho tão longo (...). ${ }^{167}$

Após alguns dias de recepção calorosa, o Padre Superior reuniu os missionários estrangeiros e determinou para qual redução seriam enviados. Antônio

\footnotetext{
${ }^{164} \mathrm{O}$ nome desta redução aparece de diversas formas nos documentos, nas cartas de Sepp e em trabalhos historiográficos. São elas: Yapeyú, Nossa Senhora de Yapeyú, Nossa Senhora dos Três Santos Reis de Yapeyú e Três Santos Reis.

${ }^{165}$ Cf. SEPP, Antônio. Viagem às Missões Jesuíticas e Trabalhos apostólicos [Introdução e notas de Wolfgang Hoffmann Harnisch; tradução de Reymundo Schneider e dos alunos da Companhia de Jesus, em Pareci] São Paulo: Martins, Edusp, 1972. pp. 47-57.

${ }^{166}$ Ibidem, p. 60.

${ }^{167}$ Ibidem.
} 
Sepp foi designado responsável pela missão na qual se encontravam, Yapeyú. O jesuíta permaneceria nesta povoação até fins de 1694.

Uma das primeiras coisas que Sepp notou na redução sob sua tutela foi a imensidão dos campos cultiváveis e a enorme quantidade de cavalos e cabeças de gado vivendo neles. Sabia, porém, que esta abundância não era exclusividade local. De sua viagem desde Buenos Aires até Yapeyú, e do posterior contato com outras regiões da Província, o missionário pode constatar:

Buenos-Aires é separada de Córdoba em Tucumã por uma enorme planície, tão plana como o Lechfeld, ${ }^{168}$ que se estende por mais de duzentas milhas até Córdoba. Sobre estas duzentas milhas não se encontrará uma só árvore que seja, mas só lindos campos lisos e pastagens. Não se encontra tão pouco uma só aldeia ou casa ou cabana de pastor, mas só milhares de reses e cavalos, que não pertencem a ninguém, mas a qualquer um que os queira ter. Basta atirar-lhes o cabresto pelo pescoço e levá-los embora. ${ }^{169}$

Antônio Sepp afirmou ainda que sua aldeia possuía um campo "infinitamente extenso", onde rebanhos incontáveis de gado pastavam o capim verde. O valor deste produto era baixíssimo, pois enquanto o ferro custava fortunas devido à carência do material, o gado e derivados de couro eram comercializados por um preço muito pequeno. O lucro advinha da quantidade: "As vacas maiores custam aqui, quando muito, 15 kreuzers, ${ }^{170}$ mas não em dinheiro, mas em valor monetário." ${ }^{171} \mathrm{O}$ próprio jesuíta nos dá uma ideia da disparidade dessas trocas comerciais envolvendo crias de animais quando diz que "aqui um apito vale mais do que o melhor e mais lindo cavalo, por causa da superabundância de cavalos e da carência de apitos." ${ }^{172} \mathrm{O}$ mesmo se dava com o gado.

Independentemente do baixo valor de troca que este produto tinha no mercado local, era uma das principais mercadorias exportadas para a Europa. Os navios que traziam produtos ao novo mundo voltavam repletos de peças de couro para serem comercializadas na Espanha:

\footnotetext{
168 Planície de Lechfeld, ao sul de Augsburgo, atual Alemanha.

169 SEPP, Antônio. Viagem às Missões Jesuíticas e Trabalhos apostólicos [Introdução e notas de Wolfgang Hoffmann Harnisch; tradução de Reymundo Schneider e dos alunos da Companhia de Jesus, em Pareci] São Paulo: Martins, Edusp, 1972, p. 41.

170 Kreuzer e Reichstaler foram moedas correntes no Sacro Império Romano-Germânico, implementadas a partir da Convenção de Leipzig, em 1556. Cf. EDVINSSON, Rodney. Foreign exchange rates in Sweden 1658-1803. In: Stockholm Papers in Economy History [8]; Stockholm, may 2009. Disponível em: http://historia.se/SPEH8.pdf. Acesso em: 15/05/2015.

${ }^{171}$ SEPP, op. cit., p. 80 .

172 Ibidem, p. 81.
} 
Nossos três navios levaram 300.000 couros para a Espanha, mas não de vacas e sim de touros mais crescidos. Aqui, um couro sai a 15 Kreuzers, que vem a ser o salário para o serviço de tirá-lo. Na Europa, no entanto, em qualquer parte, vende-se um couro de boi como este por seis ou mais Reichstaler. Daí poderá o benévolo leitor mais uma vez fazer nova conta, calculando o lucro indizível que os espanhóis tiram só do couro. São as verdadeiras minas indígenas de ouro e prata de Sua Majestade Real. ${ }^{173}$

Segundo o missionário, as vendas só eram realizadas de uma aldeia para a outra ou com os espanhóis. Isso garantia ao reino de Espanha o monopólio sobre a exploração desta mercadoria, produzida pelos indígenas reduzidos sob a direção da Companhia de Jesus.

O gado era criado livre nos pastos e bastava ao jesuíta ordenar aos indígenas que recolhessem tantas cabeças quanto desejassem. Em determinado momento, Sepp relata ter mandado um grupo de neófitos recolherem vacas para garantir a alimentação diária de sua redução naquele ano. O trabalho, que durou dois meses, teve como resultado um rebanho de 50.000 vacas, sendo que, segundo o inaciano, seus encarregados poderiam ter trazido muito mais, se assim desejasse. $\mathrm{O}$ maior trabalho consistiria não em encontrar a quantidade necessária, mas em reunir os animais sem que houvesse um estouro do rebanho e consequente dispersão. ${ }^{174} \mathrm{E}$ esta situação valeria para todas as reduções da Província Jesuítica do Paraguai. ${ }^{175}$

Levando em conta estas informações, é de se estranhar que tenha havido disputas, entre os próprios inacianos, no que se refere ao controle e posse do gado vacum. Antônio Sepp afirmava que sua redução não possuía estrebarias, que o gado era deixado no campo dia e noite e que não precisava de pastores nem guardas, "porque aqui não há ladrões."176 No entanto, quando se encontrava em meio à fundação de redução de São João Batista, o missionário recebeu ordens de seus superiores para que abandonasse o local escolhido e rumasse para outra região, mais distante da povoação de São Miguel: "A razão e causa principais eram a demasiada vizinhança de ambos os povos e, por conseguinte, fáceis demais para furtos de ambos

\footnotetext{
173 SEPP, Antônio. Viagem às Missões Jesuíticas e Trabalhos apostólicos [Introdução e notas de Wolfgang Hoffmann Harnisch; tradução de Reymundo Schneider e dos alunos da Companhia de Jesus, em Pareci] São Paulo: Martins, Edusp, 1972. p. 81.

${ }^{174}$ Para mais detalhes sobre a gerência dos rebanhos, Cf. Declaración Del Padre Francisco Ximenez Acerca De Las Vaquerías Realizadas Por Los Indios En Las Zonas De Misiones. 03/06/1706. AR-AGN.DE/CJ. Fondo Jesuíta Digital. Sala IX (410-8-695). División Colonia.

175 SEPP, op. cit., p. 81.

${ }^{176}$ Ibidem, p. 78.
} 
os lados." "177 A clareza da informação não permite, sequer, a hipótese de furtos por parte dos indígenas não reduzidos.

Uma destas disputas ocorreu em 1698 entre o padre Francisco de Avendaño, da redução de São Luís, e o padre Antônio Ximenes, procurador de redução de São Miguel. A primeira redução foi acusada de arrebatar milhares de cabeças de gado da estância de sua vizinha. Avendaño se defendeu alegando que os padres da redução de São Miguel haviam errado na contagem de suas próprias cabeças de gado:

(...) los de San Miguel no guardan fidelidad en el contar las Bacas, añadiendo i quitando conforme les esta mas a cuento, i esto se confirma com lo q sucedio agora en la repartición de Bacas q tubi con San Joan; q jusgando San Miguel q tenía 30 mil Bacas segun su Mala cuenta de ellos no se hallaron sino es dies mil: pues donde estan las 20 mil? Luego las contaron mal al principio o no cuidaron dellas (...). ${ }^{178}$

Vários pontos chamam a atenção neste documento. O primeiro é a troca de acusações entre os missionários de reduções vizinhas. ${ }^{179} \mathrm{Um}$ afirma que foi lesado no número de vacas de sua estância, ao que o outro rebate afirmando que seu irmão de Ordem não teria contado direito e que, por isso, não teria o devido controle sobre seu rebanho. As acusações e defesas são bastante elaboradas e permeiam todo o documento.

O segundo ponto é que este pleito se deu entre as missões de São Luís e São Miguel justamente no período em que Sepp era o responsável pela segunda delas. O fato de ser Antonio Ximenes e não Antonio Sepp a fazer a reclamação pode ser explicado pela forma de organização das reduções: "Cada uma é administrada por dois Padres, o que, no entanto, em virtude da grande carência de sacerdotes, nem

177 SEPP, Antônio. Viagem às Missões Jesuíticas e Trabalhos apostólicos [Introdução e notas de Wolfgang Hoffmann Harnisch; tradução de Reymundo Schneider e dos alunos da Companhia de Jesus, em Pareci] São Paulo: Martins, Edusp, 1972. p. 154.

178 Informe do Pe. Francisco de Avendaño da redução de São Luís contra o padre Antônio Ximenes da redução de São Miguel, o qual se dizia lesado por aquela nas vacas de sua estância. Acervo da Biblioteca Nacional, Rio de Janeiro. In: Manuscritos da Coleção De Angelis, vol. 5. pp. 104-110. Disponível

em: http://objdigital.bn.br/acervo_digital/div_manuscritos/mss1019246/mss1019246.pdf. Acesso em: 10/03/2014. Optamos por manter a mesma grafia encontrada na documentação.

179 Disputas como esta não se restringiram à criação de gado. O controle sobre as plantações de ervamate também gerou animosidades entre reduções. Ver: Copia De La Sentencia Dada Por El Padre Pablo Restivo A Favor Del Pueblo De La Concepcion, Como Consecuencia Del Pleito Que Mantenía Dicho Pueblo Con El De San Xavier Por La Posesión De Yerbatales. 09/12/1697. AR-AGN.DE/CJ. Fondo Jesuíta Digital. Sala IX (409-121-694). División Colonia. 
sempre se pode fazer. Por vezes, esses dois recebem ainda auxílio dum Irmão.”180

E caso concordemos com as informações apresentadas pelo padre Francisco Avendaño, isso significaria relevar os números apresentados por Sepp em suas cartas. Conforme exposto acima, o missionário relatou, quando ainda estava em Yapeyú, que facilmente conseguira arrebanhar cinquenta mil cabeças de gado e que só não juntara mais porque não havia necessidade. Afirmara, ainda, que a mesma situação se aplicava às outras reduções, o que a disputa em questão põe à prova.

Além do mais, o pleito ainda faz referência à divisão da redução de São Miguel com vistas à fundação da doutrina de São João Batista, o que também foi responsabilidade de Sepp. Segundo Avendaño, os neófitos não obedeceram às ordens dadas pelo jesuíta responsável por São Miguel, o que teria feito com que perdessem o controle das cabeças de gado:

(...) los de San Miguel, digo todos los Baqueros, se venían al Pueblo dexando las Bacas con poca g. ${ }^{\text {da }}$ de los ganados: i aunq el P. Antonio Sep. los hiso volver se quedaron todos en la sierra buscando miel; i otros q avian quedado por g. ${ }^{\text {da }}$ de las Bacas se ocuparon solamente en matar Animales de cerda; i otros en buscar venados, i otros en jugar al Gancho, i otros componiendo cueros para sus coletos: en tanto grado q los Yndios de S. Luís les avisaron varias veces como sus ganados se volvian a su querencia de los Baquerías; i ellos no hacian caso etc. ${ }^{181}$

Embora a descrição acima possa ser apenas um argumento de defesa do padre Francisco de Avendaño, baseado no que os indígenas de sua redução disseram acerca dos indígenas de São Miguel e São João Batista, ela deixa transparecer algo que Antônio Sepp irá descrever em várias situações: a necessidade de vigilância constante dos nativos reduzidos. Ainda mais no que tange à criação de gado, atividade de extrema importância na economia local, envolvendo interesses da coroa espanhola, de colonos e dos próprios inacianos, e que somada às atividades agrícolas permitiu o desenvolvimento e manutenção da sólida estrutura missioneira.

180 SEPP, Antônio. Viagem às Missões Jesuíticas e Trabalhos apostólicos [Introdução e notas de Wolfgang Hoffmann Harnisch; tradução de Reymundo Schneider e dos alunos da Companhia de Jesus, em Pareci] São Paulo: Martins, Edusp, 1972. p. 62.

${ }^{181}$ Informe do Pe. Francisco de Avendaño da redução de São Luís contra o padre Antônio Ximenes da redução de São Miguel, o qual se dizia lesado por aquela nas vacas de sua estância. Acervo da Biblioteca Nacional, Rio de Janeiro. In: Manuscritos da Coleção De Angelis, vol. 5. pp. 104-110. Disponível

em: http://objdigital.bn.br/acervo_digital/div_manuscritos/mss1019246/mss1019246.pdf. Acesso em: 10/03/2014.pp. 105-106. Optamos por manter a mesma grafia encontrada na documentação. 
2.2.4 Tutela e organização do trabalho

Antônio Sepp atuou como missionário em Yapeyú por quatro anos, tendo contribuído para torná-la um verdadeiro polo musical, como veremos no próximo capítulo. Fundada em 1626 pelo Pe. Roque González de Santa Cruz (1576-1628), contava na chegada de Sepp com mais de 5.000 almas, sendo o aldeamento mais povoado de toda a Província. ${ }^{182}$ A missão, porta de entrada para as outras reduções, proporcionou ao jesuíta suas primeiras experiências como gestor. E um ponto logo ficou claro: "O Padre precisa ser tudo a todos!"183

Em seus escritos, na parte intitulada Ordem do dia dos missionários, Sepp descreve detalhadamente todas as suas obrigações como padre responsável por uma redução. Não só os trabalhos litúrgicos exigiam o tempo do missionário, era preciso ensinar a doutrina cristã às crianças, cuidar dos doentes e visitá-los duas vezes ao dia, fiscalizar as diversas oficinas (olarias, moinhos, tecelagens, fundições etc.) para acompanhar o andamento dos trabalhos, ensinar e ensaiar os músicos e dançarinos, inspecionar as plantações, distribuir a comida, sepultar os mortos entre diversas outras tarefas, por mais pontuais que fossem. ${ }^{184}$

Ao descrever a distribuição de alimentos aos nativos, Sepp diz que seria inviável abrir mão da dupla distribuição diária. Por mais que a tarefa tomasse boa parte de seu tempo, se não o fizesse, entregando provisões maiores para todo o dia, os indígenas comeriam tudo de uma só vez:

Assim o Missionário se vê forçado a distribuir separadamente e a cada um em particular o seu pedaço de carne de cinco a oito libras, ao pai, à mãe, à filha, ao filho, e até à criança que ainda mama, e isto duas vezes por dia. Porque, se o missionário distribui ao meio dia a ração para a tarde, então já se sumiu. ${ }^{185}$

Evidente que o missionário, mesmo contando com a ajuda de um ou dois inacianos, não teria condições de manter o controle sobre uma redução deste porte a

182 HARNISCH, Wolfgang H. Introdução. In: SEPP, Antônio. Viagem às Missões Jesuíticas e Trabalhos apostólicos [Introdução e notas de Wolfgang Hoffmann Harnisch; tradução de Reymundo Schneider e dos alunos da Companhia de Jesus, em Pareci] São Paulo: Martins, Edusp, 1972. p. XXVIII.

${ }^{183}$ Ibidem, p. 63.

${ }^{184}$ Ibidem, pp. 90-93.

${ }^{185}$ SEPP, Antônio. Viagem às Missões Jesuíticas e Trabalhos apostólicos [Introdução e notas de Wolfgang Hoffmann Harnisch; tradução de Reymundo Schneider e dos alunos da Companhia de Jesus, em Pareci] São Paulo: Martins, Edusp, 1972. p. 85. 
menos que delegasse funções e se ocupasse mais em vistoriar o que era feito. Aliás, palavras como verificar, vistoriar e inspecionar são recorrentes nas descrições de Antônio Sepp: “A roça, sem dúvida, não é tão pequena por falta de terra (...) mas por pura preguiça! E não dariam conta nem deste pedacinho de roça, deste punhado de terra, se o Padre não apertasse o agricultor preguiçoso com sovas e inspeções incessantes." 186

Como vimos na disputa entre os jesuítas de São Luís e São Miguel, o padre delegou a tarefa de arrebanhar e guardar o gado a alguns indígenas. $\mathrm{O}$ mesmo se dava com todas as atividades da missão, o que implicava em uma divisão de ofícios: índios responsáveis por carnear o gado, por extrair e moldar o ferro, por plantar e colher ou por tocar e fabricar instrumentos. No entanto, isso não exclui o fato de que o mesmo neófito era, muitas vezes, responsável por atividades diversas, como o próprio missionário relata em diversas passagens. Sepp posteriormente escreveria uma série de instruções sobre as ocupações de um missionário em sua redução, sendo que na parte intitulada Como se devem distribuir os índios em todas as suas fainas, afirma:

Para governar os índios no temporal, a experiência de tantos anos e reduções me ensinou que o único modo é dividi-los em turmas. Em cada turma não devem pôr mais, antes menos, que dez, conforme os serviços, dando a cada turma um vigilante ou secretário (...). ${ }^{187}$

O que salientamos aqui é que a divisão por tarefas, já presente na cultura desses povos antes mesmo da conversão e redução, possibilitou o surgimento de mestres em cada ofício, responsáveis por determinada atividade ou oficina, que permitiam ao jesuíta circular pelo aldeamento sem se deter em algum ponto por muito tempo. A quantidade de ocupações a serem gerenciadas não permitiria ao missionário se encarregar do ensino e execução de cada trabalho manual por um tempo prolongado. Seu papel estaria mais em, justamente, verificar o andamento das tarefas, vistoriar cada parte da redução e inspecionar os indígenas para garantir que não houvesse desvios.

Após sua passagem por Yapeyú, Antônio Sepp atuou nas missões de Encarnación, Santa Maria da Fé, San Carlos e San Ignácio Guazú. Durante este período, que vai de 1694 a 1697, a Província Jesuítica do Paraguai foi assolada por

\footnotetext{
${ }^{186}$ SEPP, Antônio. Viagem às Missões Jesuíticas e Trabalhos apostólicos [Introdução e notas de Wolfgang Hoffmann Harnisch; tradução de Reymundo Schneider e dos alunos da Companhia de Jesus, em Pareci] São Paulo: Martins, Edusp, 1972. pp. 85-86.

${ }^{187}$ Ibidem, p. 84.
} 
uma epidemia de varíola que matou milhares de indígenas. O missionário teve então de atuar como médico e professor, ensinando formas de tratamento a determinados nativos que, tornados enfermeiros, se encarregariam de cuidar dos acamados, realizando sangrias e garantindo uma dieta específica visando o reestabelecimento dos doentes. A quantidade dos enfermos era tamanha, que hospitais improvisados foram construídos às pressas. O missionário ficava encarregado de vistoriar os enfermeiros, muitas vezes viajando de uma redução para outra, a fim de garantir que tudo estava sendo executado da forma indicada.

Tanto nestes casos específicos quanto no cotidiano das reduções, fica clara a necessidade de vigilância constante dos nativos. Vigilância para que executassem as tarefas conforme as instruções recebidas e vigilância para que não retomassem seus antigos hábitos. Neste contexto, os castigos daqueles que descumpriam com as normas estipuladas pelo missionário serviam de exemplo a toda a comunidade, surgindo como forma eficaz de manter a ordem.

\subsubsection{Castigos: violência e consentimento}

Os escritos do padre Antônio Sepp tornaram-se notórios por sua riqueza de detalhes e pela descrição sistemática do funcionamento das reduções. Dentro destes relatos, várias são as menções aos castigos aplicados aos indígenas por motivos diversos. Segundo Sepp, era necessário praticamente colocar as ferramentas nas mãos dos "trabalhadores preguiçosos". E caso não os ameaçasse com a punição de 24 açoites, a colheita apodreceria nos pés, as oficinas nada produziriam ou o gado se perderia, como vimos na defesa do padre Avendaño.

Antônio Sepp descreve minuciosamente a forma como os castigos eram aplicados:

Se alguém pergunta: de que maneira costumais castigar esses índios? Repondo brevemente: Como um pai castiga aos filhos que ama, assim castigamos os que merecem! Naturalmente não é o Padre que pega do açoite, mas o primeiro índio que estiver à mão aqui não temos varas de bétula ou outras semelhantes - e coça o delinquente assim como na Europa um pai surra um filho ou o patrão o seu aprendiz. Assim são castigados grandes e pequenos e também as mulheres. Castigar desta maneira paternal tem resultado extraordinário, também entre os bárbaros mais selvagens, de sorte que nos amam em verdade, como os filhos ao pai. Não haverá no mundo todo um povo que tanto nos ame. E quando se os açoita ou 
coça, não gritam, não praguejam, e tu não ouvirá uma só palavra de má vontade, impaciência ou raiva. Se o castigo for muito, invocam os santíssimos nomina Jesus Maria, e recebem a surra com a máxima paciência, sim, até gratidão. Depois de castigados, vão logo ter com o Padre, beijam-lhe a mão sacerdotal e externam seu reconhecimento nas seguintes palavras: "Meu Pai, mil e dez mil vezes te agradeço que por teu castigo paternal me abriste o juízo e me tornaste no homem que antes não fui”. ${ }^{188}$

As questões que nos intrigam a partir da leitura deste excerto e de outros já apresentados são: Como um padre sozinho conseguiu manter sob seu controle um sistema de trabalho e organização espacial que envolvia milhares de indígenas? Como estes neófitos não se revoltavam com os castigos aplicados, que inclusive variavam de intensidade, rebelando-se contra os missionários? Partimos da suposição de que para essa sociedade missioneira ter durado mais de um século, sua estrutura funcionou relativamente bem. Resta-nos perscrutar os motivos.

O contexto reducional e, de forma mais específica, a atuação do padre Sepp oferecem um campo privilegiado para verificar a aplicação de algumas hipóteses teóricas levantadas por Maurice Godelier em sua obra $O$ ideal e $o$ material. ${ }^{189}$ Em seu trabalho, o antropólogo francês afirma que duas forças fundamentam o poder dominante em qualquer sociedade: são elas a violência e o consentimento. Tais forças não seriam excludentes, conjugando-se e operando de forma distinta, mas em um mesmo sentido. E entre as duas, aquela que garantiria a manutenção e o desenvolvimento do poder seria o consentimento, entendido como "parte del poder que los dominados agregan a la que los dominantes ejercen directamente sobre ellos." 190

Dessa forma, o autor entende que o consentimento dos dominados perante os dominantes, que os faz cooperar com a reprodução de sua própria dominação, tem muito mais força do que quaisquer formas de violência aplicadas pelos dominantes sobre os dominados. E isso porque:

Para imponer y mantener en el poder a una parte de la sociedad (los hombres, un estamento, una casta o una clase), la represión cuenta

\footnotetext{
188 SEPP, Antônio. Viagem às Missões Jesuíticas e Trabalhos apostólicos [Introdução e notas de Wolfgang Hoffmann Harnisch; tradução de Reymundo Schneider e dos alunos da Companhia de Jesus, em Pareci] São Paulo: Martins, Edusp, 1972. pp. 87-88.

189 GODELIER, Maurice. Lo ideal y lo material: Pensamiento, economías, sociedades. Versión castellana de A. J. Desmont. Madrid. Taurus Humanidades, 1989. Título original: L'ídéel et le matériel (1984).

${ }^{190}$ Ibidem, p. 31.
} 
menos que la adhesión, la violencia física o psicológica menos que la convicción del pensamiento que lleva consigo la adhesión de la voluntad, la aceptación si no la cooperación de los dominados. ${ }^{191}$

Pensar que a organização reducional durou mais de um século pode levar-nos a crer que as relações estabelecidas baseavam-se em mais do que uma simples passividade, havendo aí um consentimento ativo por parte dos ameríndios. No entanto, é preciso atentar para o que diz Godelier, quando afirma que:

un consentimiento activo espontâneo no es nunca del todo espontâneo, puesto que es el resultado de una educación, de una cultura, de una formación de los hombres y las mujeres capaces de reproducir su sociedad. ${ }^{192}$

Em nosso caso, é preciso ter em mente que quando Antônio Sepp se dirigiu à Província Jesuítica do Paraguai, esta já contava com diversas reduções estabelecidas. Além disso, embora tenha fundado a missão de São João Batista em 1698, o fez através da divisão dos habitantes da redução de São Miguel, fundada inicialmente em 1632. ${ }^{193}$ Isso significa afirmar que Sepp teve de lidar nesta nova missão com uma segunda, ou até mesmo terceira, geração de indígenas reduzidos. Índios que nasceram e cresceram dentro deste universo específico e que, portanto, já eram resultado de uma outra formação, outra cultura, caracterizada pela influência de elementos ameríndios e europeus. Embora não possamos deixar de lado as diversas conversões levadas a cabo pelo jesuíta, e descritas em seus relatos, os esforços dos missionários seriam mais para manter em pleno funcionamento a estrutura vigente, na qual os ameríndios já se encontravam inseridos, do que para implementar uma nova forma de organização social. E em suas cartas, Sepp detalha minuciosamente muitas tarefas com o objetivo de demonstrar como tudo funciona bem, graças aos seus inúmeros esforços para manter os indígenas como cristãos devotos.

No entanto, a informação de que alguns ameríndios desobedeciam à ordem expressa pelo jesuíta, voltando de certa maneira aos "seus antigos costumes", fica

${ }^{191}$ GODELIER, Maurice. Lo ideal y lo material: Pensamiento, economías, sociedades. Versión castellana de A. J. Desmont. Madrid. Taurus Humanidades, 1989. Título original: L'ídéel et le matériel (1984). p. 186.

${ }^{192}$ Ibidem, p. 187.

${ }^{193}$ Sua fundação original remonta ao ano de 1632. Porém, devido aos ataques de bandeirantes que obrigaram os indígenas remanescentes a se abrigarem na redução de Conceição, teve de ser refundada em 1687. Cf. BOLLINI, Horacio. Misiones Jesuíticas - visión artística y patrimonial: Voces y emblemas en las reducciones jesuítico-guaraníes: 1609-1768. Buenos Aires: Corregidor, 2009. 
evidente em vários momentos e nos é importante. E sua importância vem da constatação de que formas de resistência existiram. Embora a documentação não nos permita ir muito além de suposições, fica claro que nem tudo ocorria de forma perfeitamente ordenada, como o inaciano buscava retratar. Como afirma Godelier: "el consentimiento, aun si es pasivo, nunca lo comparten todos los individuos y todos los grupos de la sociedad (...)."194

E para deixar claro que não só os indígenas consentiam com as imposições do jesuíta e que eram necessários constantes acordos e negociações para o pleno funcionamento da estrutura missioneira, vale comentar brevemente um episódio envolvendo a fundação da redução de São João Batista. Ainda em 1697, Antônio Sepp foi encarregado pela missão de São Miguel. No mesmo ano, devido à superpopulação deste aldeamento, o padre provincial ordenou que o jesuíta fundasse um novo povoado a partir da divisão de sua redução. O missionário destina páginas e mais páginas de seus relatos à descrição desta tarefa, levada a cabo entre 1697 e 1710 , e trabalhos de historiadores, arqueólogos e arquitetos já se ocuparam deste acontecimento sob diversos aspectos. ${ }^{195} \mathrm{O}$ que nos interessa aqui é o fato de que após a escolha do local e do início das atividades de plantio e construção da nova missão, o padre Sepp recebeu de seus superiores ordens de abandonar a área e escolher uma região mais distante. Como dissemos anteriormente, havia um receio de que furtos ocorressem devido à proximidade de São João Batista e São Miguel.

O missionário questiona a ordem recebida e utiliza como argumento o receio de que os indígenas se revoltassem em ter de se mudar novamente, já tendo realizado tantos trabalhos na fundação da nova redução. Na divisão de São Miguel, Sepp havia reunido os principais caciques e os convencido da necessidade de transferirem suas famílias para um novo local. Agora, o missionário temia não contar com o mesmo apoio e por isso insistiu que a nova redução permanecesse onde estava. O jesuíta e seus superiores tiveram de ceder para manter sob controle os indígenas reduzidos:

Lavrara já a maior parte do campo, lançara à terra trigo índico e outros legumes, plantara aquele imenso campo de algodão, quando recebo ordens de abandonar esta minha estação, para explorar outra além do grande rio denominado Ijuí, e fundar mais distante do

${ }^{194}$ GODELIER, Maurice. Lo ideal y lo material: Pensamiento, economías, sociedades. Versión castellana de A. J. Desmont. Madrid. Taurus Humanidades, 1989. Título original: L'ídéel et le matériel (1984). p. 187.

195 BOLLINI, Horacio. Misiones Jesuíticas - visión artística y patrimonial: Voces y emblemas en las reducciones jesuítico-guaraníes: 1609-1768. Buenos Aires: Corregidor, 2009. pp. 311-316. 
antigo povoado uma nova redução. (...) Além disso, não pouco perigo havia que os índios, em outro tempo afeiçoados e submissos, regredissem e, tornando-se pouco a pouco indispostos comigo e desencabeçados, me negassem a obediência e o amor filial que até então me votavam. E, para tocar na chaga viva, não se magoariam, não se impacientariam, não se enfureceriam eles de ter que abandonar, de uma hora para outra, tantos campos já regados por seu suor, lavrados com o trabalho de suas mãos, campos que já estavam por verdejar e prometiam fruto centuplicado? ${ }^{196}$

Se levarmos em conta novamente o fato de que as missões existiram e funcionaram por mais de cem anos, podemos supor que embora existissem diversas formas de resistência, como o próprio Sepp deixa transparecer em seus relatos, tais atos seriam pontuais ou não teriam força o suficiente para fazer o sistema ruir. E isso não se dava devido a uma força opressora centralizada na figura do dominante. Para Godelier, nenhuma sociedade se constitui ou se reproduz apenas por haver uma força opressora. As pessoas aderem voluntariamente a esses sistemas de opressão. Ou seja, os índios também se submeteram. A violência não basta para instituir uma sociedade. ${ }^{197}$ E isso é verificável, inclusive, na aplicação de castigos:

Se alguém abater o seu animal e for descoberto, o delinquente será atado a um tendão de boi, e o capitão (corregedor) lhe infringirá a pena de vinte e quatro açoites. E assim querendo eu contar os meus bois, julguei que no mínimo acharia dois mil e, ó decepção! apenas encontro trezentas juntas, e nem isto. Ó estômago! Ó glutonice inaudita! ${ }^{198}$

Por mais que Sepp aplicasse punições aos que não o obedecessem, jamais conseguiria castigar a todos, vigiar a todos. Vale lembrar que o missionário foi responsável pela fundação e administração da redução de São João Batista, que no ano de 1715, por exemplo, contava com 3.025 almas. ${ }^{199}$ Ele teria, obviamente, de contar com membros do próprio grupo dos dominados para que a ordem fosse mantida. Os próprios indígenas eram responsáveis, alguns deles, por aplicar os castigos em seus irmãos, como vimos no trecho acima. Além disso, como nos aponta

\footnotetext{
196 SEPP, Antônio. Viagem às Missões Jesuíticas e Trabalhos apostólicos [Introdução e notas de Wolfgang Hoffmann Harnisch; tradução de Reymundo Schneider e dos alunos da Companhia de Jesus, em Pareci] São Paulo: Martins, Edusp, 1972. pp. 154-155.

${ }^{197}$ GODELIER, Maurice. Lo ideal y lo material: Pensamiento, economías, sociedades. Versión castellana de A. J. Desmont. Madrid. Taurus Humanidades, 1989. Título original: L'ídéel et le matériel (1984). p. 11.

${ }^{198}$ SEPP, op. cit., p. 142.

${ }^{199}$ Estado De Las Reducciones De Los Ríos Parana Y Uruguay En El Año 1715. 31/12/1715. ARAGN.DE/CJ. Fondo Jesuíta Digital. Sala IX (410-229-695). División Colonia.
} 
Godelier, o poder dominante tem sempre o recurso de uma ameaça virtual de uso da violência, caso o consentimento enfraqueça ou dê lugar à rejeição ou à resistência. $O$ fato é que "no existe dominación sin violencia, ni siquiera cuando ésta se limita a ser un telón de fondo." 200

Ainda no que diz respeito aos atos de resistência, vale a pena observamos o necrológio do padre Sepp, escrito pelo irmão de ordem Pedro Lozano:

Ya que el Padre tenía un celo tan ardiente en promover la salud de los indios, excitó contra si el odio más grande de parte del demonio, y muchas y graves persecuciones. La más sensible fue aquella por la cual unos hombres perdidos, dignos de ministros de Satanás, quisieron tachar su angelical pureza, levantando contra el inocente una atroz calumnia. No descansaron los calumniadores hasta lograr que el Padre fuera depuesto de su oficio y vergonzosamente desterrado de la reducción que gobernaba. ${ }^{201}$

Segundo o documento, o padre Antônio Sepp foi acusado, pelos próprios indígenas reduzidos, de má conduta (ao que tudo indica, envolvimento com índias) e acabou sendo afastado da redução. É importante notarmos que, de acordo com o que nos relata Lozano, os neófitos não descansaram "hasta lograr que el Padre fuera depuesto de su oficio". Isso implica dizer que as denúncias foram recorrentes ou que a única denúncia feita foi levada a cabo de maneira bastante enfática.

De acordo com o historiador Guillermo Furlong: "los superiores determinaram sacar de esa población, a lo menos temporariamente, al buen misionero y destinarle a otra reducción."202 Tal informação implica afirmar que os indígenas recorreram às instâncias superiores na hierarquia da Ordem para que o missionário fosse retirado de suas funções. Biógrafo de Sepp, o jesuíta Arthur Rabuske apresenta em seu livro uma tabela cronológica da atuação do missionário na qual nota-se um lapso de quatro anos entre o afastamento e retorno à redução de São João Batista. ${ }^{203}$

Por mais que a resistência dos ameríndios tenha levado o missionário a ser rejeitado, afastado e "vergonzosamente desterrado", tudo se deu dentro da lógica do

200 GODELIER, Maurice. Lo ideal y lo material: Pensamiento, economías, sociedades. Versión castellana de A. J. Desmont. Madrid. Taurus Humanidades, 1989. Título original: L'ídéel et le matériel (1984). p. 187.

${ }^{201}$ LOZANO, Pedro S. J. Necrológio do P. Antônio Sepp S. J. In: FURLONG, Guillermo S.J. Antonio Sepp y su "gobierno temporal" (1732). Buenos Aires: Ediciones Theoria, 1962. pp. 51-52.

202 FURLONG, Guillermo S.J. Antonio Sepp y su "gobierno temporal" (1732). Buenos Aires: Ediciones Theoria, 1962. p. 51.

${ }^{203}$ RABUSKe, Arthur S.J. Pe. Antônio Sepp, SJ - O Gênio das Reduções Guaranis. 3.ed. São Leopoldo: Editora Unisinos, 2003. p. 12. 
sistema. Os indígenas não o mataram como fariam com seus antigos inimigos, mas o denunciaram às instâncias superiores que o retiraram de seu posto e, supomos, o substituíram por outro jesuíta, mesmo que em caráter provisório. ${ }^{204}$ Prova de que não houve ruptura quanto à organização social é Antônio Sepp ter retornado à antiga redução:

Entonces el Padre Sepp fue restituido honoríficamente a su puesto antigo, donde, como antes, prosiguió trabajando con fervor, como si nada hubiera sucedido. Algunos le aconsejaban que no diera ocasión a mal entendidos con algunos procedimentos suyos, pero él estaba seguro de su oportuno modo de preceder y contestó que jamás dejaría, por miedo, de cumplir con su deber y con lo que era del servicio de Dios. ${ }^{205}$

Em sua obra, Maurice Godelier afirma que o funcionamento e a reprodução das relações de produção em contextos como esse baseiam-se no "equilíbrio" entre violência e consentimento. Só o castigo não basta, pois não é possível sustentar um poder opressivo sem dar-lhe o caráter de uma troca, sem legitimá-lo. É necessário que o indígena identifique seus próprios interesses com os de seu senhor, acabando por colaborar com sua própria situação servil. É preciso que se estabeleça uma relação de compromisso entre dominantes e dominados na qual o poder dos dominantes seja tão legítimo para os dominados quanto seu dever de servi-los. ${ }^{206}$

\subsubsection{O missionário experiente}

Após mais de uma década em São João Batista, entre idas e vindas devido ao seu afastamento, Antônio Sepp atuou por três anos na redução de São Luís Gonzaga (entre 1710 e 1713), um em San Javier (entre 1713 e 1714), dezesseis na missão de La Cruz (entre 1714 e 1730) e mais três em San José, onde faleceria em 13 de janeiro de 1733. Ao todo, o jesuíta trabalhou por 42 anos em mais de uma dezena de reduções e certamente acumulou um enorme conhecimento prático sobre a organização dos povoamentos e sobre a gestão de seus aspectos espirituais e temporais.

\footnotetext{
${ }^{204}$ Não encontramos, através de análise de documentos do período, o nome de um possível substituto para o lapso de tempo em que Sepp esteve afastado da redução.

${ }^{205}$ LOZANO, Pedro S. J. Necrológio do P. Antônio Sepp S. J. In: FURLONG, Guillermo S.J. Antonio Sepp y su "gobierno temporal" (1732). Buenos Aires: Ediciones Theoria, 1962. p. 52.

206 GODELIER, Maurice. Lo ideal y lo material: Pensamiento, economías, sociedades. Versión castellana de A. J. Desmont. Madrid. Taurus Humanidades, 1989. Título original: L'ídéel et le matériel (1984). p. 188.
} 
Diversos documentos presentes no Archivo Genenal de la Nación Argentina nos ajudam a rastrear a atuação do missionário nos anos após a fundação de São João Batista. Vale lembrar que as cartas que compõe Viagem às Missões Jesuíticas e Trabalhos Apostólicos abarcam apenas o período que vai de 1691 a 1700. Estas outras evidências demonstram que nos anos subsequentes, Antônio Sepp continuou trabalhando na tutela dos indígenas reduzidos, preparando-os para as mais diversas ocupações.

Como exemplo, temos o Memorial Del Padre Viceprovincial Luys De La Roca Para El Padre Superior Del Pueblo De La Cruz, do ano de $1714 .^{207}$ Nele constam ordens do padre provincial para que o missionário continue treinando os neófitos em exercícios militares. Já no Memorial Del Padre Provincial Ignacio De Arteaga Para El Pueblo De La Cruz, de $1727,{ }^{208}$ as instruções são para que Sepp construa uma igreja maior assim que possível, tendo em vista o crescimento da população. Vemos ainda uma carta do próprio missionário, enviada em 1731 ao Padre Procurador das Missões, referindo-se às contas da missão de San José e descrevendo algumas atividades econômicas. ${ }^{209}$

Com toda a bagagem adquirida em suas décadas de trabalho junto aos indígenas reduzidos, Antônio Sepp escreve em 1732 Algumas instruções relativas ao governo temporal das reduções em suas fábricas, sementeiras, estâncias e outras fainas. A obra, claramente destinada a novos missionários, tem caráter pedagógico ao abordar em detalhes cada uma das atividades de que deve se ocupar um inaciano para o bom funcionamento de uma missão. Além da já habitual riqueza de detalhes, as instruções impressionam pelo domínio apresentado por Sepp na lida de tão variada gama de atividades. ${ }^{210} \mathrm{O}$ missionário certamente buscava passar adiante tudo que

${ }^{207}$ Memorial Del Padre Viceprovincial Luys De La Roca Para El Padre Superior Del Pueblo De La Cruz. 25/05/1714. AR-AGN.DE/CJ. Fondo Jesuíta Digital. Sala IX (410-174-695). División Colonia.

${ }^{208}$ Memorial Del Padre Provincial Ignacio De Arteaga Para El Pueblo De La Cruz. 31/07/1727. AR-AGN.DE/CJ. Fondo Jesuíta Digital. Sala IX (411-260-696). División Colonia.

209 Carta Del Padre Antonio Sepp Al Padre Procurador De Misiones Thomas Verle Sobre Liquidación De Cuentas De Establecimientos De La Compañía De Jesús. 18/10/1731. ARAGN.DE/CJ. Fondo Jesuíta Digital. Sala IX (411-409-696). División Colonia.

${ }^{210}$ O livro está dividido nos seguintes temas: Construções, Telhas, Telhado, Chácaras e sementeiras, algodoais, O milho, Ervais, Estâncias, Ovelhas, Tosquia, Repartição dos Novilhos e Touros à gente, Como se devem distribuir os índios em todas as suas fainas, Adobes, Carretas, Conduzir toradas para as reduções, Queimar telhas, Vinha, Podá-los, Vindima, Cozimento, Trasfega do vinho, Conservar melancias e tunas de um ano a outro, Modo de semear milho para que tenham milho verde até maio para comer, Chains, Tabaco, Quando se deve atar os bois ao trabalho, Fiar, Tecer, Para fazer o bom pão mesmo em tempo de frio. Cf. SEPP, Antônio. Algumas instruções relativas ao governo temporal das reduções em suas fábricas, sementeiras, estâncias e outras fainas. In: RABUSKE, Arthur S.J. Pe. Antônio Sepp, SJ - O Gênio das Reduções Guaranis. 2.ed. São 
havia aprendido. Morreria um ano depois, aos 77 anos de idade.

No primeiro capítulo, apresentamos uma série de trabalhos dedicados à vida e obra do jesuíta Antônio Sepp. Buscamos aqui apresentar uma visão não restrita a informações biográficas e a uma mera sequência cronológica de acontecimentos. Tampouco era nossa intenção uma apresentação panorâmica dos fatos. O objetivo era destacar momentos e aspectos que consideramos cruciais em sua formação e analisar fatos geralmente não abordados de sua atuação missionária. Desta forma, algumas passagens de sua vida foram tratadas de forma mais aprofundada, enquanto outras, extensamente trabalhadas em outras pesquisas, foram deixadas de lado. Nossa intenção era apresentar a trajetória de Antônio Sepp, evidenciando situações que se relacionam diretamente com as práticas musicais no contexto das reduções, como veremos a seguir. 


\section{A MÚSICA INSTRUMENTO}

A música adquiriu diversas funções no universo missioneiro. Além de ter facilitado uma aproximação entre jesuítas e indígenas desde os primeiros contatos, ela se mostrou importantíssima nas relações surgidas através do estabelecimento das reduções, tendo se tornado um elemento privilegiado de estudo destas.

Neste ambiente repleto de sonoridades, as práticas musicais assumiram diversos papéis. Desde os sinos que chamavam todos para a missa até as celebrações litúrgicas ou festas elaboradas para padres visitadores, que contavam com composições executadas por músicos indígenas, formados nas escolas presentes nas próprias reduções. Em suas cartas, o padre Antônio Sepp nos dá claros indícios da presença da música no cotidiano das reduções. Ao descrever as atividades diárias das quais os missionários estavam encarregados, diz:

De manhã, uma hora antes do romper do dia, desperta-me meu garoto indígena, de nome Francisco Xavier. O rapazote é acordado pelo sacristão, e este pelo galo que canta. (...) Depois o sino grande dá a Ave-Maria, quando o sol já raiou dá-se o sinal para a Santa Missa. (...) Vou depois ter com os músicos, Ora ouço o canto dos tiples, ${ }^{211}$ de que tenho oito; outras vezes a dos altos, de que tenho seis. Os tenores são incontáveis; tenho seis baixos. Depois tocam os quatro trombetas, os oito charameleiros e os quatro trompas, dando sua lição. Dou lição aos quatro harpistas, os quatro organistas e a um tiorbista. (...) Depois que instrui os músicos e dançarinos, visito as outras oficinas, a olaria, o moinho, a padaria. (...) Pelas dez e meia horas o rapazote dá o sinal com o sino para o exame de consciência. Para isso, fecho-me por um quarto de hora em meu quarto, examino meus pecados e omissões e vou então à mesa. À mesa, o melhor dos tiples me lê em latim um capítulo da Sagrada Escritura. (...) Pela uma hora rezamos na igreja, com as crianças, a ladainha de Todos os Santos. Tenho então, até as duas horas, um pouco de tempo para trabalhar para mim: Faço de cola diversas imagens de Alt-Oetingen, depois medalhas e relicários de seda. Noutro dia componho um pouco de música, e diàriamente vou aprendendo um pouco mais da língua indígena. Às duas horas o sino grande dá o sinal de trabalhar. ${ }^{212}$

Sons regem a rotina de padres e neófitos, acompanhando os trabalhadores nas lidas no campo, marcando o tempo e os afazeres e auxiliando jesuítas na transmissão

211 "Tiple [Sp]: Soprano, upper voice. Also, a small guitar." In: RAENDEL, Don Michael. The Harvard Dictionary of Music. 4th ed. Cambridge, Massachusetts and London, England. The Belknap Press of Harvard University Press. 2003 (1986). p. 895.

${ }^{212}$ SEPP, Antônio. Viagem às Missões Jesuíticas e Trabalhos apostólicos [Introdução e notas de Wolfgang Hoffmann Harnisch; tradução de Reymundo Schneider e dos alunos da Companhia de Jesus, em Pareci] São Paulo: Martins, Edusp, 1972. pp. 90-92. 
de elementos da doutrina católica enquanto permitem aos indígenas uma assimilação e ressignificação de elementos culturais exógenos. Neste sentido, o estudo da música nas missões exige uma compreensão cada vez maior da diversidade e complexidade das culturas com as quais os missionários e colonos se depararam. A interdisciplinaridade mostra-se essencial nesta tarefa, buscando luzes na Antropologia, Arqueologia e História com o objetivo de esclarecer melhor elementos culturais dos povos guaranis e possibilitar a reconstrução de um cenário mais elaborado deste período, que não analise o contato através de um único viés, o europeu, predominante em decorrência das fontes escritas.

Este capítulo objetiva abordar as práticas musicais de acordo com suas diversas funções, utilizações e apropriações no contexto das reduções. O tema não é novo e, conforme apresentamos anteriormente, historiadores, musicólogos e pesquisadores de diversas áreas já se debruçaram sobre vários de seus aspectos. No entanto, assim como no capítulo anterior, são as experiências de Antônio Sepp que norteiam a abordagem de cada ponto aqui tratado. E como antes, alguns temas receberam maior atenção enquanto outros, como a importância da música no processo de catequese, não foram trabalhados. ${ }^{213} \mathrm{~A}$ ideia central é enxergar a música como "instrumento" executado, de formas variadas, tanto pelo missionário quanto por indígenas na construção das relações surgidas nas reduções.

\subsection{A música missioneira}

Ao falarmos sobre a música executada nas missões é impossível não nos perguntarmos de que música estamos falando. Provavelmente, a maior dificuldade em se estudar o assunto seja de caráter classificatório. Diversos pesquisadores, em especial musicólogos, têm se debruçado sobre o tema e originado nomenclaturas diferentes, que refletem questões conceituais. Em geral, a música das missões é incluída dentro do contexto do barroco como uma arte da Contra-Reforma, vinculada

\footnotetext{
${ }^{213}$ Pesquisas como, por exemplo, as de Daniela Ribeiro Pereira e Luisa Tombini Wittmann já trataram do tema de forma bastante completa. Cf. PEREIRA, D. R. "Si soy misionero es porque canto, bailo y toco música": para uma história social da música na Provincia Paracuaria (1680-1768). 2011. 164f. Dissertação de Mestrado. PUCRS, Porto Alegre. 2011. Disponível em: http://tede.pucrs.br/tde_busca/arquivo.php?codArquivo=3678. Acesso em: 15/04/2015; WITTMANN, Luisa T. Flautas e maracás: música nas aldeias jesuíticas da América Portuguesa (XVI-XVII). 2011. 266f. Tese de Doutorado em História. UNICAMP, Campinas. 2011. Disponível em: www.bibliotecadigital.unicamp.br/document/?down=000802385. Acesso em: 13/04/2015.
} 
especialmente à Companhia de Jesus em seu empenho por trazer, das mãos do protestantismo, as almas perdidas. Muitos trabalhos qualificam diretamente o barroco como "arte jesuítica", caracterizando-o como veículo propagandista, que recorre a elementos como o contraste e o exagero emocional como ferramentas para comover o povo e reconduzi-lo à doutrina católica. Um exemplo, que embora se atenha às artes plásticas deixa claras as características acima, é a formulação de Werner Weisbach:

El catolicismo, cuya universalidad era ya sólo un supuesto, se vió obligado para satisfacer a la masa, para ganársela y sujetarla, a acoger y favorecer sus tendencias materialista y sus intereses. (...) De este modo un elemento retórico, excitante, estimulante, es aceptado en el catolicismo de la contrarreforma y de ello participa su arte. ${ }^{214}$

No entanto, esta classificação embora possa parecer óbvia, não deve ser encarada como conclusiva. Enquanto alguns estudiosos se satisfazem ao falar em música barroca, outros falam de barroco latino, missioneiro, ou, de forma mais distintiva, em música colonial hispanoamericana ou iberoamericana, fazendo clara referência à colonização imposta pelas coroas ibéricas. ${ }^{215}$ Guillermo Wilde, ao defrontar-se com este problema no estudo das celebrações existentes nas missões, afirma:

No existe acuerdo pleno sobre los límites del término barroco para Europa, menos aún para el contexto que nos ocupa. Por otra parte, se sabe que el impulso tridentino tuvo respuestas muy disitintas según el caso; puede decirse, adapataciones locales. De allí que muchas de las viejas clasificaciones resulten en algún punto insuficientes; a veces incluso proyectan en bloque concepciones parcial o totalmente ajenas a la de la sociedade estudiada. ${ }^{216}$

${ }^{214}$ WEISBACH, Werner. El barroco: arte de la contrarreforma. 2.ed. Traduccíon y ensayo preliminar de Enrique Lafuente Ferrari. Madrid, Espasa-Calpe, 1948. p. 312.

${ }^{215}$ Diversos trabalhos do musicólogo Leonardo Waisman abordam a questão, trazendo considerações relevantes à compreensão deste problema. Cf. WAISMAN, Leonardo. Corelli entre los índios, o Utopia desconstruye Arcádia. In: Concierto Barroco. Estudios sobre música, dramaturgia e historia cultural, ed. J. J. Carreras and M. A. Marín. Logroño, 2004. pp. 227-254. Disponível em: https://www.academia.edu/3814665/Corelli_entre_los_indios_o_Utopia_deconstruye_Arcadia. Acesso em: 15/10/2012; WAISMAN, Leonardo. Musica Del Barroco Misional: ¿Un Concepto o un Slogan?. In: WILDE, Guillermo (org.). Saberes de la Conversión - Jesuítas, Indígenas e Impérios Coloniales en las Fronteras de la Cristiandad. Buenos Aires: Editora Sb, 2011.

${ }^{216}$ WILDE, Guillermo. Poderes del ritual y rituales del poder: un análisis de las celebraciones en los pueblos jesuíticos de Guaraníes. In: Revista Española de Antropologia Americana. n. 33. 2003. pp. 203-29. Disponível em: http://www.google.com.br/search?q=guillermo+wilde+poderes+del+ritual\&ie=utf-8\&oe=utf$8 \& \mathrm{aq}=\mathrm{t} \& \mathrm{rls}=$ org.mozilla:en-US:official\&client=firefox-a\&gfe_rd=cr\&ei=RvARUifCMai8wfN0oDoAQ. Acesso em: 01/03/2014. 
O termo "barroco missioneiro", que também aparece como "barroco missional", é frequente na classificação da música que se executava nas missões jesuíticas da América do Sul nos séculos XVII e XVIII. Leonardo Waisman propõe, em seu texto Musica del barroco missional: ¿Un concepto o un slogan?, que a reflexão se volte, previamente, para o esclarecimento do que queremos dizer com barroco, mesmo que esquematicamente, já que o conceito demandaria centenas de páginas, e de como a música das missões dialoga com essa definição.

Se procurarmos o termo "barroco" nos dicionários, encontraremos, entre outras definições: muito ornamentado, sobrecarregado, exuberante, irregular. ${ }^{217} \mathrm{E}$ talvez estas qualidades sejam as que de forma mais obstinada têm resistido aos embates disciplinares por converter a palavra em um conceito delimitado e preciso. Existem também diversas definições do barroco baseadas em características de estilo. A maioria delas são específicas de um campo artístico, outras pretendem uma maior generalidade, demonstrada através de analogias entre as diversas manifestações artísticas.

Como é possível perceber pela simples comparação das informações presente em diferentes dicionários musicais, uma definição estilística do barroco musical é bem improvável, já que a única característica mais frequente dentre o período que vai de 1600 a 1750 é o uso do baixo contínuo. ${ }^{218}$ Desta forma, classificar uma música como barroca corresponderia a designá-la como música ocidental do período entre 1600 e 1750, o que, claramente, é muito vago e abstrato.

Outro ponto a ser levantado é que enquanto em campos como História da Arte, Literatura ou Arquitetura, é comum considerar o barroco como uma segunda etapa do renascimento, uma etapa inicialmente concebida como decadente, logo reinterpretada como criativamente transgressora, ${ }^{219}$ na música, apesar das inevitáveis

${ }^{217}$ HOLANDA, Aurélio Buarque de. Novo Dicionário da Língua Portuguesa. Rio de Janeiro, Editora Nova Fronteira, 1975. p. 189.

218 "Baroque. The period of Western music history extending from the end of the 16th century to ca, 1750; also the musical styles of that period." In: RAENDEL, Don Michael. The Harvard Dictionary of Music. 4th ed. Cambridge, Massachusetts and London, England. The Belknap Press of Harvard University Press. 2003 (1986). p. 41. Quanto ao baixo contínuo, thorougbass em inglês, diz o dicionário musical: "Thoroughbass. An independent bass line continuing throughout a piece (whence the Italian continuo), on the basis of wich harmonies are extemporized on keyboard or other chord-playing instruments [...] The thorougbass method was essential to ensemble music in Europe from about 1600 to about 1750 , the period sometimes called the thoroughbass period." In: RAENDEL, op. cit. p. 890.

219 WÖLFFLIN apud WAISMAN, Musica Del Barroco Misional: ¿Un Concepto o un Slogan?. In: WILDE, Guillermo (org.). Saberes de la Conversión - Jesuítas, Indígenas e Impérios Coloniales 
continuidades, são absolutamente evidentes as muitas rupturas estéticas e os novos pontos de partida técnicos. Conceber o barroco musical como um segundo estágio do renascimento seria possível, segundo Waisman, só "mediante una compleja manipulación de abstraciones, que contradice la evidencia auditiva de 'sentido común."'220

Para tentarmos esclarecer a questão é preciso ter em conta que o que se conserva da música das missões é obra de europeus, ${ }^{221}$ ao menos em sua grande maioria, passível de observação através dos surpreendentes arquivos musicais de Moxos e Chiquitos (Bolívia). Vale lembrar que muitos deles nem chegaram a pisar na América. O elemento indígena seria perceptível na execução, porém das maneiras de executar dos conjuntos musicais das missões sabemos quase nada, sendo que a imagem auditiva que nos sugere o estudo de uma partitura missioneira está praticamente condicionada pelo que sabemos das práticas europeias contemporâneas. O pouco que se pode deduzir das escassas evidências sobre a "performance" missioneira se opõe à noção corrente de barroco: os músicos índios, diferente dos europeus, executavam em um tom neutro e sem ornamentações. Segundo Waisman:

Si las principales características estético-estilísticas del barroco en las diversas artes son el tensionamento, la complejidad, el contraste y la sensualidad, ¿qué hacemos con una música que, comparada con los modelos europeos, reduce todo esto al mínimo? 222

Infelizmente não há registros das composições feitas pelo padre Antônio Sepp durante sua atuação missionária. Então, para exemplificar o que foi dito acima, optamos por utilizar Domenico Zipoli (1688-1726), compositor contemporâneo de Sepp e apontado pelos jesuítas como modelo do que devia ser a música nas reduções. Zipoli compôs diversas obras sacras para as missões jesuíticas dos atuais Paraguai e Bolívia que nos permitem observar interessantes adaptações para as circunstâncias locais, como na peça Gloria (da Missa San Ignácio). Não sabemos, ainda que seja inteiramente possível, se modificou sua música composta na Europa para o uso na América, mas sim que adaptou seu estilo de composição as novas circunstancias,

\footnotetext{
en las Fronteras de la Cristiandad. Buenos Aires: Editora Sb, 2011. p. 334.

${ }^{220}$ Ibidem, p. 335.

221 Cf. ZÍPOLI, Domenico. Misa San Ignacio; Ave Maris Stella; Laudate Dominum; Tantum ergo; Beatus vir; Ad Mariam; Confitebro de (...): recopilación y transcipción Luis Szarán; edicción y coordinacióngeneral Gisela von Thümen. 2. ed. Asunción: Missions Prokur S.J. Nürnberg, 1999. 202p.

${ }^{222}$ WAISMAN, op. cit., p. 337.
} 
simplificando-o, fazendo-o "menos barroco". ${ }^{223}$ Segundo Paulo Castagna, a música missionária de Domenico Zipoli era composta para coro e conjunto instrumental, como era comum na música sacra europeia, mas evitava, por exemplo, incluir um baixo vocal, ou então incluir um baixo muito grave, pois esse tipo de voz era raro entre os indígenas. Com freqüência, as partes de violino 1 e 2 se fundem em uma só, para facilitar o trabalho do conjunto musical. Até mesmo partes para instrumentos tradicionais indígenas foram encontradas em várias obras musicais deste compositor jesuíta. ${ }^{224}$ E parece-nos difícil de acreditar que a maneira indígena de cantar e de tocar seus instrumentos, da qual trataremos em tópico posterior, não tenha marcado uma música interpretada por eles mesmos.

Assim, se estas composições fossem escutadas nas catedrais europeias, sem dúvida estariam entre as menos aptas para convencer por meio do assombro, da sensualidade, do dramatismo. Mas como seus destinatários eram indígenas com ouvidos acostumados a músicas com "menor riqueza" de recursos sonoros, este "barroco amansado" pode ter soado igualmente esplêndido e ornamentado. Infelizmente, só o que sabemos, através de inúmeros relatos não só de missionários como também de viajantes e colonos, é que os ameríndios gostaram destas novas sonoridades e até certo ponto se apropriaram delas. Nos resta, portanto, só o fato de que era uma música efetiva em sua função de proselitismo religioso, e isto não é suficiente para dar-lhe o mote de "barroca".

Waisman ainda afirma que no cotidiano das missões, as músicas mais executadas não eram estas composições, mas simples canções, em cuja realização monofônica participavam os próprios fiéis, a partir de acomodações com viés catequético e devocional feitas pelos missionários em melodias populares de sua terra natal. Ou até mesmo melodias tradicionais indígenas, já que tais adaptações eram frequentes na vida litúrgico-musical missionária. ${ }^{225} \mathrm{E}$ este método de participação musical do povo visando uma incorporação da fé, característica de muitos movimentos protestantes, não se inscreve dentro de nenhum dos cânones até agora propostos para o barroco, justamente por desprivilegiar a teatralidade e o espetáculo

${ }^{223}$ Cf. SZARÁN, Luis. Domenico Zipoli (1688-1726): Una vida, un enigma. Nurenberg: Fundación Paracuaria - Missionsprokur S.J., 2005.

${ }^{224}$ Cf. CASTAGNA, P. A. Alma Latina: música das Américas sob domínio europeu - I [texto dos programas 1 a 4]. Revista Portuguesa de História do Livro. v. 29-30, p. 627-654, 2012.

225 WAISMAN, Leonardo. Musica Del Barroco Misional: ¿Un Concepto o un Slogan?. In: WILDE, Guillermo (org.). Saberes de la Conversión - Jesuítas, Indígenas e Impérios Coloniales en las Fronteras de la Cristiandad. Buenos Aires: Editora Sb, 2011. p. 340. 
em favor de uma participação emocional.

Assim, chamar de "barroco missioneiro" a música das reduções jesuíticas pode apenas nos ajudar a colocar este objeto dentro de um recorte temporal bastante vago e simplório, com relação ao contexto que nos interessa. Embora as práticas musicais desenvolvidas nas reduções jesuíticas encontrem-se de certa forma enraizadas no barroco europeu, elas se originaram de modificações estilísticas efetuadas de acordo com as condições locais, sejam elas técnicas ou materiais. Desta forma, utilizaremos aqui o termo "música missioneira", isto é, aquela surgida no contexto da experiência missionária dos padres jesuítas junto aos indígenas na Província Jesuítica do Paraguai.

\subsection{A importância da música para os indígenas}

A atribuição de poder e importância à música é um dado comum a diversas culturas. No caso dos grupos indígenas com os quais os jesuítas travaram contato nas reduções paraguaias, não é diferente. As pesquisas envolvendo o universo missioneiro prestam cada vez mais atenção às cosmologias ameríndias. Isso porque durante muito tempo os trabalhos sobre esta temática omitiram considerações acerca da participação indígena na estrutura reducional que levassem em conta elementos culturais dos povos nativos, tanto no que se refere às lógicas e dinâmicas particulares destes grupos, quanto no que concerne à sua capacidade para incorporar e ressignificar elementos prévios no novo cenário de contato.

Sepp explicita o apreço dos índios pela música logo na primeira das cartas que compõem os seus relatos de viagem. Ao descrever estes "paraguaios cristãos" com os quais estabelecera contato, afirma:

Não há que eles mais apreciem do que a música. Quando lhes mostrei meus instrumentos e composições da Europa e quando lhes toquei um pouco (porque muito não sei) em gratidão a Deus por todos os benefícios, não puderam conter-se e quase me adoraram como a um deus. ${ }^{226}$

Segundo Luísa Tombini Wittmann: "Para os índios, a experiência do corpo era evidente. A do tempo, alargada. A espiritualidade indígena não era racionalizada

\footnotetext{
${ }^{226}$ SEPP, Antônio. Viagem às Missões Jesuíticas e Trabalhos apostólicos [Introdução e notas de Wolfgang Hoffmann Harnisch; tradução de Reymundo Schneider e dos alunos da Companhia de Jesus, em Pareci] São Paulo: Martins, Edusp, 1972. p. 9.
} 
como a dos letrados jesuítas, mas sensorial, corporal, musical."227 O prazer que manifestavam em expressá-la, desde os primeiros momentos do contato, fez com que os padres inacianos se utilizassem da música como meio de se aproximarem e estabeleceram comunicação com os grupos contatados. Vale lembrar que os missionários da Companhia de Jesus valiam-se do modelo paulino de adaptação ao outro, utilizando aspectos da cultura ameríndia como base para conduzi-los à devoção católica. Dito de outra forma: "Tocam sua música, para tocar seu coração."228

No entanto, ao levar em consideração apenas a habilidade dos inacianos em atrair os ameríndios através da música e da celebração, sem refletir sobre suas bases culturais e sua visão de mundo, nas quais a palavra e o canto já ocupavam papéis centrais, a historiografia missioneira, até meados da década de 1990, explicitou o quão incomum era a abordagem da enorme complexidade da cultura indígena. Conforme expõe Maria Cristina Bohn Martins:

Assim é que se tem realçado a ideia de que os índios deixavam-se seduzir pela música, pelo gosto que tinham dela, sem se destacar, com igual ênfase, a relação prévia que eles faziam entre a música, o canto e a palavra religiosa. ${ }^{229}$

Trabalhos historiográficos tendem a separar as manifestações musicais e de dança, desagregando-as dos contextos rituais nos quais se punham em prática e nos quais adquiriam sentido. Esta operação analítica responde a uma concepção moderna de arte, entendida como esfera separada e autônoma da vida social; concepção que não condiz com o contexto aqui analisado. É necessário apresentar elementos da cosmologia Guarani se quisermos fazer inferências sobre a recepção dos simbolismos, sonoridades e rituais cristãos pelos neófitos paraguaios. Por exemplo: se levarmos em conta que na cultura Tupi-Guarani a experiência coletiva muitas vezes se dá através de sonoridades, de cantos, talvez consigamos compreender o motivo pelo qual o canto de órgão (polifônico, com várias vozes) obteve grande aceitação entre os neófitos reduzidos e esteve presente em procissões, celebrações e recepções a padres

227 WITTMANN, Luisa T. Flautas e maracás: música nas aldeias jesuíticas da América Portuguesa (XVI-XVII). 2011. 266f. Tese de Doutorado em História. UNICAMP, Campinas. 2011. p. 197. Disponível em: www.bibliotecadigital.unicamp.br/document/?down=000802385. Acesso em: 13/04/2015.

${ }^{228}$ Idem, p. 166.

${ }^{229}$ MARTINS apud PEREIRA, D. R. "Si soy misionero es porque canto, bailo y toco música": para uma história social da música na Provincia Paracuaria (1680-1768). 2011. 164f. Dissertação de Mestrado. PUCRS, Porto Alegre. 2011. p. 61. Disponível em: http://tede.pucrs.br/tde_busca/arquivo.php?codArquivo=3678. Acesso em: 15/04/2015. 
visitadores, tendo sido amplamente registrado por missionários, cronistas e viajantes.

O papel dos sons na cosmologia ameríndia é central. É através deles que se expressam, que vivem seus rituais mais significativos. ${ }^{230} \mathrm{O}$ estudo das relações estabelecidas no contato entre jesuítas e ameríndios demanda um entendimento sobretudo de momentos ritualísticos, liderados por pajés e xamãs ${ }^{231}$ e intrinsecamente ligados a manifestações sonoras.

Bartomeu Melià afirma que a religião dos Guarani atuais tem em sua estrutura e função a perpetuação das crenças de seus ancestrais, e pode ser definida como "inspiração, sacramentada no canto e na dança, dirigida pelos 'profetas' em busca da terra sem males". ${ }^{232}$ Em contato com o europeu jesuíta, essa religião "profundamente religiosa", como atesta Melià, que já é historicamente dualista (entre o ser e o divino, entre o humano e o não humano), vê-se socialmente dividida, ideologizada a partir de uma cultura estranha. Coloca-se então o problema para os xamãs e sacerdotes guaranis da imposição de uma nova dinâmica religiosa, estrangeira e discriminatória, que pode significar a perda da liberdade antiga. ${ }^{233}$

No que diz respeito ao registro das experiências musicais presenciadas, Antônio Sepp sempre enfatizou passagens em que ameríndios cantam músicas ensinadas pelos europeus e participam de cerimônias católicas. O juízo da música indígena dava-se de duas formas. Se demonstrava aproximação com os nativos, tornava-se aliada. Dentre os vários exemplos, segue trecho em que Sepp relata sua comoção ao ouvir, pela primeira vez, crianças indígenas entoando hinos católicos: "(...) quem queria e poderia conter-se em face das pobres criancinhas indígenas, tão escassamente vestidas e que no país de pagãos bárbaros e ferozes entoavam um hino de glórias à Rainha dos Céus?"234

Porém, se demonstrava o poder dos chefes indígenas ou algum costume antropófago, era ameaçadora dissonância, execrada pelo jesuíta. Não eram raras

${ }^{230}$ WITTMANN, Luisa T. Flautas e maracás: música nas aldeias jesuíticas da América Portuguesa (XVI-XVII). 2011. 266f. Tese de Doutorado em História. UNICAMP, Campinas. 2011. p. 132. Disponível em: www.bibliotecadigital.unicamp.br/document/?down $=000802385$. Acesso em: 13/04/2015.

${ }^{231}$ Utilizaremos o termo xamã, mais comum na abordagem de povos das terras baixas amazônicas, por ser o utilizado pelos antropólogos cujos trabalhos apresentamos aqui. Será empregado como sinônimo de pajé, para designar o especialista ritual, aquele que tem o poder e a atribuição de comunicar-se com as diversas potências e seres não humanos.

232 MELIÀ, Bartomeu. El guarani conquistado y reduzido: ensayos de etnohistoria. Asunción: Universidad Católica, 1988. p. 162.

${ }^{233}$ Idem, p. 163.

${ }^{234}$ SEPP, Antônio. Viagem às Missões Jesuíticas e Trabalhos apostólicos [Introdução e notas de Wolfgang Hoffmann Harnisch; tradução de Reymundo Schneider e dos alunos da Companhia de Jesus, em Pareci] São Paulo: Martins, Edusp, 1972. p. 56 
interpretações que ligavam a música indígena às ações do diabo, já que inseridas em rituais liderados por seus principais adversários na conquista espiritual dos Guarani, os pajés.

Portanto, ao considerarmos que a cosmologia Guarani era impregnada de sons, fica evidente a importância da utilização regular de práticas musicais pelos missionários europeus como facilitador de contato, como um método adaptado à cultura daqueles cuja conversão e devoção buscavam atingir. Da mesma forma, estes indígenas, ao aceitarem a música dos padres jesuítas, entendiam que ela possibilitava a comunicação com o Deus cristão, já que, como afirma Sztutman, os indígenas admitiam a possibilidade de xamãs-cristãos. ${ }^{235}$ Impossibilitados de realizar seus próprios rituais, ao menos da forma como faziam antes do processo reducional, era através dos sons e rituais trazidos de outro continente, pertencentes a outra cultura, que os neófitos poderiam tentar perpetuar algumas de suas tradições e crenças. Além disso, a música europeia de caráter sacro também objetivava o encontro com instâncias transcendentais, e tinha seus próprios embates na tentativa de se aproximar dela. Neste caso, de atingir o sagrado.

Deise Montardo estudou a música no universo Mbyá, e concluiu que "não há possibilidade de vida na Terra se os Guarani não estiverem cantando e dançando". A explicação dada por seus informantes, em 2002, foi a de que:

O sol, ou o dono do Sol, o herói criador, é responsável por manter a sonoridade do mundo durante o dia. Durante a noite, essa responsabilidade é dos homens. (...) O Sol, o Pa'i Kuara é um xamã, e ele canta e toca seus instrumentos durante o dia. Durante a noite os homens são responsáveis por tocar, cantar e dançar, o que têm que fazer para manter o mundo, a vida na Terra. ${ }^{236}$

Embora a diferença temporal seja grande, e o contexto outro, é possível notarmos similaridades entre os grupos contatados pela antropóloga e aqueles convertidos e reduzidos pelos missionários no que concerne à importância dada às práticas musicais. Montardo nos explicita o fato de que para estes subgrupos Guarani com os quais desenvolveu sua pesquisa, é papel dos homens tocar, cantar e dançar

${ }^{235}$ SZTUTMAN, R. O Profeta e o Principal: A Ação política ameríndia e seus personagens. São Paulo: EDUSP. FAPESP. 2012.

${ }^{236}$ MONTARDO, Deise Lucy. Através do Mbaraka: Música, Dança e Xamanismo Guarani. São Paulo: Editora da Universidade de São Paulo, 2009. p. 13. 
durante a noite, já que durante o dia o responsável por isso é o Sol.

Ora, nas reduções temos toda uma nova dinâmica e organização temporal, pautada pelos rituais, pelas missas, pelos sinos, que transferem para o transcorrer do dia a celebração da música. Desta forma, se ela originalmente já existe e é executada para comunicar-se com o universo metafísico, as chances de os povos reduzidos terem interpretado a música apresentada pelos jesuítas de modo a abarcar várias acepções, servindo também às suas crenças originais, não deve, nem pode ser descartada.

Pedro Cesarino, ${ }^{237}$ ao estudar as implicações conceituais de estruturações paralelas presentes em cantos e narrativas xamânicas de populações indígenas provenientes, principalmente, das Terras Baixas da América do Sul, traz contribuições que podem lançar novas luzes à análise do contato entre ameríndios e jesuítas no período colonial. Cesarino inicia seu artigo retomando diversos autores que se debruçaram sobre o estudo do paralelismo ${ }^{238}$ para, daí, reforçar sua visão de que este não pode ser visto como expressão de uma pretensa capacidade limitada e redundante de primitivas mentes indígenas, encarceradas na repetição. Baseado em grande parte nos trabalhos de Jakobson ${ }^{239}$, o autor coloca-se ao lado daqueles que enxergam o paralelismo como procedimento poético intencional, como "essência mesma do artifício poético". ${ }^{240}$

Assim, o antropólogo busca compreender a serviço de que configurações cosmopráticas o paralelismo se apresenta nos cantos xamanísticos, entendidos por ele como "um vasto campo de expressões verbais cantadas ou entoadas e cuja estilização e padronização (...) vêm a destacá-las do fluxo da linguagem cotidiana (...) para se engajar nas diversas situações de empregos vinculados às cosmopraxis xamanísticas (...)". ${ }^{241}$ Vários estudos de caso são então apresentados, como a análise de um canto dos Nenets siberianos ou as "histórias verdadeiras", akinhá ekugu, dos Kuikuro do alto Xingu, com o intuito de demonstrar a multiplicidade de funções implícitas na

${ }^{237}$ CESARINO, P.N. De duplos e estereoscópios: paralelismo e personificação nos cantos xamanísticos ameríndios. In: Mana. 12 (1): 105-134. 2006. Disponível em: http://www.scielo.br/scielo.php?script=sci_arttext\&pid=S0104-93132006000100004. Acessado em: 20/10/2014.

${ }^{238}$ Cesarino apresenta a definição técnica proposta por Finnegan: "uma espécie de repetição (em geral padrão binário) na qual um elemento é trocado e o outro (em geral a própria estrutura sintática) permanece constante". Cf. FINNEGAN, Ruth. Oral Poetry. Bloomington: Indiana University Press. 1992.

${ }^{239}$ Os trabalhos citados por Cesarino são: JAKOBSON. Roman. Poesia da gramática e gramática da poesia. In: Linguística, poética, cinema. São Paulo: Perspectiva, 1970; JAKOBSON, Roman. Il parallelismo grammaticale e il suo aspetto russo. In: Poesia e poetica. Torino: Einaudi. 1985.

${ }^{240}$ CESARINO, op. cit. p. 106.

${ }^{241}$ Ibidem, p. 107. 
replicação e variação de termos e a amplitude deste mundo narrativo dos cantos, que se desdobra em mundo dos vivos, espaço de encontro entre duplos de vivos e mortos, dos espíritos etc.

Em alguns momentos, o paralelismo e a forma musical aparecem para favorecer a visualização, e não a narração, das viagens efetuadas pelo xamã; em outros, serve de importante índice para se acompanhar a passagem da língua ordinária às falas rituais, como acontece no caso da "língua dos antigos" Kaxinawá, marcada por um gradiente de formalização; alguns casos, ainda, explicitam o uso agentivo das repetições e variações, como nos cantos de cura do "mestre das dores", ahituma arotu, dos Warao. Em todos eles, porém, nota-se a presença do paralelismo com finalidades claras e não como fruto de limitações congênitas.

A partir da análise feita por Simoncsics ${ }^{242}$ de um canto dos Nenets siberianos, Pedro Cesarino traz à tona uma distinção que muito nos interessa, por permitir estabelecer relações com o que encontramos nos relatos dos missionários jesuítas. É ela a distinção entre a autoridade do narrador e de cantadores envolvidos em dinâmicas xamanísticas. Para o antropólogo, enquanto os cantos xamanísticos tenderiam a jogar com evidências de experiência imediata e mediada (hearsays), de modo a colocar o xamã/cantador na própria cena que narra, nas narrativas míticas o narrador atuaria como um arauto dos feitos de outros, ancorando-se justamente neste "ouvir dizer" para respaldar sua autoridade diante de um saber imemorial. Cesarino diz:

se, nas narrativas, a visualização encontra-se subsumida pela autoridade mediatizada de algum narrador, nos cantos parece acontecer o contrário. É antes a própria visualização que transmite a evidência e constitui a fonte primeira de carga epistêmica da palavra que se quer verdadeira, não por remeter sua competência a uma fonte ancestral, mas por ser justamente o próprio locutor a autoridade e a fonte imediata do que comunica, bem como o depositário das expectativas de eficácia de seus feitos. ${ }^{243}$

Partindo destas reflexões, podemos supor que um dos objetivos da utilização de cantos e ladainhas em procissões ou no ritual cristão da missa, realizado em

${ }^{242}$ SIMONCSICS, Péter. The structure of a Nenets magic chant. In: DIÓSZEGI, V.; HOPPÁL, M. (orgs.). Shamanism in Siberia. Budapeste: Akadémiaia Kiadó. pp. 378-402.

${ }^{243}$ CESARINO, P.N. De duplos e estereoscópios: paralelismo e personificação nos cantos xamanísticos ameríndios. In: Mana. 12 (1): 105-134. 2006. p. 109. Disponível em: http://www.scielo.br/scielo.php?script=sci_arttext\&pid=S0104-93132006000100004. Acessado em: 20/10/2014 
ambientes planejados detalhadamente e nos quais se sucediam múltiplas sugestões visuais e atos dirigidos com a finalidade de envolver através do assombro ou admiração, os missionários poderiam transmitir a liturgia católica de forma diferente do que pela catequese, por exemplo. Enquanto nesta última os jesuítas se portavam como narradores, detentores de um saber imemorial, neste caso os dogmas católicos, nos cantos litúrgicos a experiência sonora, como cantos de penitência, atrelados à profusão de pinturas retratando as penúrias do inferno presentes nas igrejas, por exemplo, serviriam também para colocar os padres (xamãs/cantadores) na posição de protagonistas que realmente vivenciavam aquilo que estavam narrando.

Nossa hipótese encontra lastro nas práticas místicas dos inacianos, fundamentadas nos Exercícios Espirituais, ${ }^{244}$ que Ignácio de Loyola compôs em Manresa, entre 1531 e 1548. A espiritualidade jesuíta, herdeira da devotio moderna, vale-se de uma ideia central, presente na Teologia e na Retórica medievais. Trata-se da noção "imaginar", não com o significado de transcriar ou ficcionalizar, criar enredos ou narrativas irreais, mas de compreender realidades transcendentes por imagens (a imago medieval), encontrando na mente - logos humano - as imagens que permitem acessar e decodificar essas realidades, colocando-se in persona na própria narrativa da História da Salvação, sentindo "na pele", por exemplo, as dores do Cristo ou o júbilo da graça celestial. Desta maneira, os inacianos penetram não em um intervalo na regularidade do tempo ordinário, mas na temporalidade sempre reatualizada do mito cristão enquanto narrativa da redenção, assemelhando-se, assim, à experiência de viagem efetuada pelos xamãs indígenas.

Infelizmente, no caso dos índios Guarani convertidos e reduzidos pelos jesuítas no território da Província Jesuítica do Paraguai, não temos conhecimento de canções ou melodias transcritas que nos permitam uma análise nos moldes da de Cesarino. Apenas os relatos de missionários (em alguns casos, verdadeiros etnógrafos), viajantes e colonos nos dão indícios de elementos culturais dos povos ameríndios. Suposições, no entanto, são possíveis mediante comparações dos escritos destes personagens com etnografias modernas.

\footnotetext{
${ }^{244}$ Os Exercícios Espirituais de Inácio de Loyola constituem um rígido manual de conduta através do qual, por meio de exercícios praticados com disciplina, durante quatro semanas, busca-se um aperfeiçoamento da espiritualidade do praticante. A primeira semana trata da purificação dos pecados, bem como da morte e do julgamento dos homens. Os exercícios da segunda e terceira semana referem-se à profunda contemplação da existência, tendo sempre como modelo a vida de Cristo. A última semana representa a busca de uma íntima relação com Jesus Cristo. Para mais, acessar: http://interativo.jesuitasbrasil.org/painel/\#/. Acesso em: 16/01/2015.
} 
O padre Sepp, em muitos momentos, realça a exatidão das habilidades artísticas indígenas, enaltecendo a perfeição com que cada nota era reproduzida ou cada escultura era talhada. O foco parece estar sempre na reprodução exata do original e não na capacidade de improvisação. Ao discorrer sobre as habilidades manuais dos ameríndios, afirma:

Estes índios são tão pueris, tão grandemente simplórios e de juízo tão curto (...). Não são capazes de inventar e excogitar algo que seja de seu próprio juízo e intuição, mesmo que fosse o mais simples trabalho manual mas sempre precisa estar o Padre junto deles e orientá-los e fornecer-lhes moldes e modelos. Quando os tiverem, pode estar seguro de que o farão bem igualzinho ao original. ${ }^{245}$

Nota-se que a compreensão daquele que escreve é escassa diante das manifestações do Outro, cujos elementos constitutivos de sua cultura lhe escapam. Na quase totalidade das citações, o significado da música e das expressões verbais indígenas se perde quando transformada em relato pelo missionário, interpretados e transcritos à luz de uma tradição racionalista própria à experiência intelectual do Ocidente.

Ora, se levarmos em conta o que nos diz Pedro Cesarino acerca das múltiplas funções implícitas no paralelismo, sobre a intencionalidade e a diversidade de objetivos implicados nos procedimentos poéticos presentes nas expressões verbais ameríndias, passa a ter lógica não a ideia de uma inaptidão para a criação artística, mas a consciência de uma necessidade de repetição "exata" da música ensinada pelo padre, já que a motivação principal no fazer música é a crença em seu potencial ritualístico. Modificar ou incrementar as composições não teria sentido já que não caberia aos índios músicos ditar os cantos e melodias que possuíam o poder de estabelecer contato com o mundo dos não humanos, dos espíritos.

Da mesma forma que cabia aos xamãs, através do ritual, o poder de comunicação com o não-humano, por meio das sonoridades de flautas e maracás, dos cantos xamanísticos, do uso do tabaco, da ingestão do cauim, cabia agora aos padres, detentores de agência e mestres da palavra, ditarem quais eram as melodias que possibilitariam este contato. E estas deveriam ser executadas da forma indicada, para

\footnotetext{
245 SEPP, Antônio. Viagem às Missões Jesuíticas e Trabalhos apostólicos [Introdução e notas de Wolfgang Hoffmann Harnisch; tradução de Reymundo Schneider e dos alunos da Companhia de Jesus, em Pareci] São Paulo: Martins, Edusp, 1972. p. 82.
} 
não comprometer o ritual. Assim como para Cesarino ${ }^{246}$, o trabalho de Strathern ${ }^{247}$ também ilumina nosso ponto ao afirmar ser a estética, no caso melanésio, de acordo com sua eficácia, com sua capacidade de cumprir tarefas, e não imediatamente sobre beleza, o que aqui significaria ornamentação e improviso musical baseados em preceitos europeus e ocidentais.

Ainda com relação à multiplicidade de funções relacionadas aos cantos xamanísticos, podemos recorrer a Tânia Stolze Lima. ${ }^{248}$ Ao analisar as relações engendradas pelo cauim, a autora apresenta os diversos aspectos da vida social dos Yudjá do rio Xingu, buscando demonstrar que a pessoa, para este grupo, se realiza na sociabilidade forjada nas cauinagens, isto é, através destas festas de bebida. E estas festividades, evidentemente, são repletas de sonoridades ritualísticas, como por exemplo o festival das clarinetas que, segundo os Yudjá, faz com que o número de crianças se multiplique, ou o festival das plantas cultivadas, cujos cantos propiciariam o crescimento das plantas. ${ }^{249}$

Interessante notar que a presença massiva de cantos e instrumentos musicais nestes festivais é minuciosamente detalhada pela antropóloga. A longa preparação do evento e o convite de índios de outros lugares para que se juntassem para beber e cantar durante dias e noites revela, ainda, um sentido e funcionalidade em sons compartilhados. Pensando no contex to missioneiro e levando em conta o que sabemos dos povos Guarani, é possível supor que estes elementos acabaram auxiliando a entrada de jesuítas em aldeias indígenas e, já em regime de redução, geraram uma recepção positiva de celebrações cristãs coletivas que, por meio de música, apresentassem significados religiosos e objetivos específicos, como as procissões em favor de boas colheitas ou da restituição da saúde da população, assolada por uma peste.

${ }^{246}$ CESARINO, P.N. De duplos e estereoscópios: paralelismo e personificação nos cantos xamanísticos ameríndios. In: Mana. 12 (1): 105-134. 2006. Disponível em: http://www.scielo.br/scielo.php?script=sci_arttext\&pid=S0104-93132006000100004. Acessado em: 20/10/2014. p. 125.

247 O trabalho citado por Cesarino é: STRATHERN, Marilyn. The gender of the gift. Berkeley: University of California Press. 1988.

${ }^{248}$ LIMA, Tânia S. Um peixe olhou para mim: O Povo Yudjá e a perspectiva. São Paulo: Editora UNESP: ISA: Rio de Janeiro: NuTL. 2005.

${ }^{249}$ Ibidem, pp. 194-205. 


\subsection{Ensino musical}

Nos escritos deixados por Antônio Sepp, as referências às práticas musicais são mais constantes e sistemáticas no período em que se encontrava na redução de Yapeyú. A obra Viagem às missões jesuíticas, por exemplo, apresenta várias referências ao ensino da música aos neófitos e aos instrumentos ensinados. Se lembrarmos que as cartas que a compõem foram escritas em 1691, chega-se à conclusão de que a data corresponde ao início das atividades missionárias de Sepp, quando foi designado para a redução de Yapeyú.

Guillermo Furlong S.J. afirma que dentre as missões da Província Paracuaria, esta "llegara a ser el gran emporio musical" 250 e Rabuske complementa ao dizer que as atividades de Antônio Sepp em Yapeyú contribuíram "para a melhor formação musical das mais diversas reduções". ${ }^{251}$ Embora tenha aperfeiçoado o ensino musical dado aos indígenas, Sepp deixa claro que não foi o responsável por introduzi-lo:

Quem ensinou a esses pobres índios abandonados à doutrina cristã, quem os ensinou a rezar o santo Padre-Nosso, a cozer o pão, a fazer roupas, a cozinhar, pintar, fundir sinos, tocar órgão e harpa, corneta, charamela e trombeta (...) quem lhes ensinou tudo isto, também os instruiu na música e nos ofícios: Foram os primeiros Padres Missionários, nossos santos predecessores, especialmente alguns Padres neerlandeses, cujo trabalho e esforço aqui não foram esquecidos e cuja memória nós abençoamos. Estes ensinaram aos índios a cantar, de resto com extremo esforço e trabalho, porque de suas composições pode-se depreender que não eram músicos profissionais, mas só criaram de fantasia. ${ }^{252}$

O missionário deparou-se com uma estrutura de ensino musical que, embora amadora, já estava instalada e em funcionamento. Na continuação de seu relato, afirma que após estes padres, um de nacionalidade espanhola, "que entendia um pouco mais", deu novo ânimo aos ensinamentos, mas que tudo ainda era feito de maneira muito antiga e atrasada, tendo em conta os avanços musicais surgidos na Europa. Como vimos no capítulo anterior, Sepp teve sua formação em meio a um cenário de grande florescimento e desenvolvimento de técnicas musicais; por isso

250 FURLONG, Guillermo S.J. Antonio Sepp y su "gobierno temporal" (1732). Buenos Aires: Ediciones Theoria, 1962. p. 62.

251 RABUSKE, Arthur S.J. Pe. Antônio Sepp, SJ - O Gênio das Reduções Guaranis. 3.ed. São Leopoldo: Editora Unisinos, 2003. p. 120.

${ }^{252}$ SEPP, Antônio. Viagem às Missões Jesuíticas e Trabalhos apostólicos [Introdução e notas de Wolfgang Hoffmann Harnisch; tradução de Reymundo Schneider e dos alunos da Companhia de Jesus, em Pareci] São Paulo: Martins, Edusp, 1972. p. 73. 
estranhava esta música feita "à maneira antiga". Vimos também que muitos missionários eram formados pela pressão das circunstâncias durante seu período de espera para vir às missões. É evidente que tal era o caso dos jesuítas a que o padre Sepp se refere: mais dedicados do que profissionais. ${ }^{253}$

Para Jacqueline Ahlert, é justamente a frota de navios que trouxe Antônio Sepp e outros jesuítas centro-europeus à América que marca o início de "uma etapa de grandes mudanças artísticas nos povoados jesuítico-guaranis." ${ }^{254}$ Estes navios trariam alguns especialistas como o escultor, arquiteto e pintor José Brasanelli (1659-1728), além do próprio Sepp, que introduziriam inovações substanciais nas formas musicais, arquitetônicas e esculturais. Caberia a este último a introdução do estilo moderno, série de inovações nas formas de se fazer música surgidas, principalmente, na Itália do século XVII:

(...) Os missionários me enviam seus músicos de todos os pontos cardeais e de mais de cem milhas de distância, para que eu os instrua nessa arte [ou seja, o estilo moderno], que é completamente nova para eles e difere da velha música espanhola que eles têm, como o dia da noite. Até agora não sabiam nada de nossas divisões de compassos, nada de proporção tripla, e nada das cifras 7-6, 4-3, etc. Até hoje, os espanhóis - como vi em Sevilha e Cádiz - não tem colcheias, nem fusas, nem semifusas. Suas notas são todas brancas: as semibreves, as mínimas e as semínimas, que são parecidas com as notas quadradas da velha música litúrgica. É música antiquíssima, como os livros velhos dos quais os copiadores da Província alemã possuem caixotes inteiros e que utilizam para encadernar autores $(\ldots)^{255}$

${ }^{253}$ Entre os missionários predecessores de Antônio Sepp e com registros de atuação musical junto às reduções paraguaias temos, destacadamente, Jean Vaisseau S.J. (1583-1623) e Louis Berger S.J. (1590- 1643). Cf. PREISS, Jorge Hirt. A música nas missões jesuíticas nos séculos XVII e XVIII. Porto Alegre: Martins Livreiro Editor, 1988. pp. 19-28.

${ }^{254}$ AHLERT, Jacqueline. Amálgamas culturais e representações imagéticas nas doutrinas da Província Jesuítica do Paraguai. In: Sæculum - Revista de História [28]; João Pessoa, jan./jun. 2013. pp. 6781. p. 77. Disponível em: http://periodicos.ufpb.br/ojs/index.php/srh/article/view/18189. Acesso em: 10/04/2015.

${ }^{255}$ Este trecho é uma adaptação feita por Paulo Castagna que, ao analisar as traduções da obra de Sepp em três línguas diferentes, efetuou algumas alterações nos termos musicais, em geral grafados de forma equivocada. Cf. CASTAGNA, P. A. Estilo antigo e estilo moderno na música antiga latinoamericana. In: Apostila do curso História da Música Brasileira. São Paulo, Instituto de Artes da Unesp, $2004 . \quad$ pp. $\quad 8-9 . \quad$ Disponível em: http://www.ia.unesp.br/Home/AreadoAluno/HMB_2004_apostila05.pdf. Acesso em: 04/03/2014. O trecho, na tradução da obra de Sepp para o português, encontra-se na página 76. Cf. SEPP, Antônio. Viagem às Missões Jesuíticas e Trabalhos apostólicos [Introdução e notas de Wolfgang Hoffmann Harnisch; tradução de Reymundo Schneider e dos alunos da Companhia de Jesus, em Pareci] São Paulo: Martins, Edusp, 1972. p. 76. 
Para além das inovações técnicas introduzidas por Antônio Sepp, ${ }^{256}$ importa a afirmação de que outros missionários enviavam indígenas de suas reduções, "de mais de cem milhas de distância", para que fossem instruídos musicalmente em Yapeyú. Furlong afirma, inclusive, que devido à proximidade do povoamento com Buenos Aires, a redução também "acudia gente das cidades coloniais espanholas." 257 Vale ressaltar que Sepp já havia ensinado alguns escravos negros do novo governador durante sua travessia à América.

Estas informações atestam certa proeminência da missão de Yapeyú quanto ao ensino musical. Corroboram também a importância de Antônio Sepp para a renovação da música praticada na Província Jesuítica do Paraguai. O missionário era o responsável por ensinar não só os indígenas de sua redução, mas de muitas outras, além de aceitar alunos vindos de cidades coloniais. Segundo o pesquisador Jorge Hirt Preiss, quando Sepp iniciou seus trabalhos missionários, cada missão já contava com sua própria escola de canto coral, música e dança, onde se aprendia a tocar todos os tipos de instrumentos cujo uso era permitido nas igrejas. Preiss afirma ainda que Yapeyú se constituiu em uma espécie de escola nacional de música, "para a qual eram selecionados os mais talentosos alunos de cada redução." 258

Os músicos instruídos por Antônio Sepp se encarregariam de passar os aprendizados a outros, disseminando o estilo moderno entre as reduções. Além disso, as partituras conseguidas a duras penas pelo jesuíta, como vimos anteriormente, eram multiplicadas por copistas indígenas treinados para este fim, o que potencializava a disseminação musical:

Obras anónimas - atribuibles quizás a jesuitas o a músicos indios -, obras de Zipoli, Schmid, copiadas por los pacientes calígrafos indios circulaban de pueblo en pueblo: de ese modo se alimentaba la pedagogía musical en las misiones y la prática activa de ese arte. ${ }^{259}$

\footnotetext{
${ }^{256}$ Horacio Bollini descreve em detalhes as inovações introduzidas por Antônio Sepp, relacionando-as com o aprendizado que o missionário obteve com mestres europeus como Johann Melchior Glettle e outros. Faz ainda uma análise dos instrumentos utilizados e descritos por Sepp, apresentando a função de cada um no acompanhamento da música vocal. Cf. BOLLINI, Horacio. Arte en las Misiones Jesuíticas: Los espejos del Mundo Jesuítico-Guaraní. Buenos Aires: Corregidor, 2007. pp. 194-204.

${ }^{257}$ FURLONG apud RABUSKe, Arthur S.J. Pe. Antônio Sepp, SJ - O Gênio das Reduções Guaranis. 3.ed. São Leopoldo: Editora Unisinos, 2003. p. 123. Certamente deveriam se tratar de filhos, ou escravos negros, de governadores ou pessoas de maior destaque na sociedade colonial, já que os jesuítas eram bastante rigorosos quanto à entrada de colonos em seus aldeamentos devido à influência negativa que representavam aos índios reduzidos.

${ }^{258}$ PREISS, Jorge Hirt. A música nas missões jesuíticas nos séculos XVII e XVIII. Porto Alegre: Martins Livreiro Editor, 1988. p. 21.

${ }^{259}$ BOLLINI, op. cit., 182. Prova desta intensa circulação é que grande parte das partituras descobertas
} 
Assim como nos diversos ofícios que requeriam a tutela do missionário, era necessário delegar funções, formar mestres que possibilitassem o cumprimento das tarefas. Seria impossível ao padre Sepp, por exemplo, lecionar música aos índios de sua redução e deslocar-se para outras localidades com o mesmo intuito. A precisão de vigilância constante gerava a necessidade de formar especialistas neste e em outros ofícios. Quanto a este processo, Sepp relata:

Neste ano já consegui fazer mestres nos respectivos instrumentos: Seis trombetas de diversas reduções, três bons tiorbistas, quatro organistas. A estes ainda não cheguei a mostrar uma partitura, porque seria muito difícil para eles, mas só estudei com eles certas árias, preâmbulos e fugas. Oh! Como tudo isto me é difícil! Levei este ano trinta charameleiros, dez cornetas e dez fagotes a ponto de já saberem tocar e cantar todas as minhas composições. Além disso, já tenho mais de cinquenta tiples, que têm vozes boas. ${ }^{260}$

Tomando em conta este excerto, podemos dizer que em apenas um ano o inaciano formou treze mestres em instrumentos variados, instruiu mais quarenta músicos ao ponto de executarem suas composições de forma satisfatória, além de treinar mais de cinquenta cantores. Em uma estrutura organizacional como a missioneira, em que as atividades musicais assumiram diversos e importantes papéis, pode-se imaginar o impacto da escola musical de Yapeyú e dos trabalhos do Padre Sepp. Evidente que o missionário colheu frutos deste esforço:

Todos os missionários estão muito satisfeitos e agradecem ao sumo Deus por lhes haver enviado, após tantos anos, um homem que agora também imprime à música um novo impulso. Em reconhecimento, este me manda uma barriquinha de mel, o outro açúcar e frutas americanas. ${ }^{261}$

Interessante ainda é notarmos que o conceito de "mestres nos respectivos instrumentos" diz mais quanto às habilidades técnicas dos índios músicos do que quanto aos seus conhecimentos teóricos. Os indígenas formados em trombeta, tiorba e

nos arquivos de Chiquitos e Moxos (na atual Bolívia) são cópias de peças produzidas nas missões localizadas às margens dos rios Uruguai e Paraguai. Para mais ver: SZARÁN, Luis; NESTOSA, Jose. Música en las Reducciones Jesuíticas de América Del Sur. 2a Edición. Asunción: Missionsprokur, 1999.

${ }^{260}$ SEPP, Antônio. Viagem às Missões Jesuíticas e Trabalhos apostólicos [Introdução e notas de Wolfgang Hoffmann Harnisch; tradução de Reymundo Schneider e dos alunos da Companhia de Jesus, em Pareci] São Paulo: Martins, Edusp, 1972. pp. 76-77.

${ }^{261}$ Ibidem, p. 77. 
órgão naquele ano sabiam executar seus instrumentos ao ponto de o missionário considerá-los mestres. Porém, não sabiam ler partituras já que "seria muito difícil para eles". Evidente que havia indígenas capazes de ler a música, mas estes devem ter surgido posteriormente. A prioridade, no primeiro ano de atuação missionária de Antônio Sepp, certamente era suprir as reduções com membros capazes de executar a música litúrgica, mesmo que de memória. Vale lembrar que o jesuíta ainda não dominava o idioma guarani, o que dificultaria ainda mais qualquer tentativa de ensino de leitura musical. No entanto, se os músicos formados nos anos e décadas seguintes não tivessem aprendido a ler partituras, não haveria muito sentido na grande copiagem e disseminação destas, como vimos acima.

Neste ensino inicial, Sepp devia assemelhar-se aos antigos professores jesuítas que disse terem passado pela Província Paracuaria. Ao descrever seus métodos, diz que precisavam repetir as lições "tantas vezes quantas eram precisas, até entrar nas cabeças duras." 262 Tática idêntica à usada pelo inaciano quando ensinou peças para os negros escravos durante sua viagem ao novo continente. O modelo pedagógico certamente tinha a seu favor a "capacidade imitativa" dos nativos, tópica presente em inúmeras fontes, particularmente jesuítas, e ressaltada por Sepp em muitas passagens: "[Estes índios] são muito aplicados e imitam tudo o que vêem." ${ }^{263}$ Soma-se a isso a organização extremamente metódica de Antônio Sepp. O próprio missionário descreve a condução de suas aulas, diárias:

Ora ouço o canto dos tiples, de que tenho oito; outras vezes a dos altos, de que tenho seis. Os tenores são incontáveis; tenho seis baixos. Depois tocam os quatro trombetas, os oito charameleiros e os quatro trompas, dando sua lição. Dou lição aos quatro harpistas, os quatro organistas e a um tiorbista. ${ }^{264}$

Outro ponto de destaque é a variedade de instrumentos utilizados e ensinados. Levando em conta a dificuldade de obtenção de quaisquer produtos vindos da Europa, sem falar nos preços exorbitantes que estas mercadorias adquiriam, a presença de diversos instrumentos impressiona e atesta a importância da música no contexto local. Muitas vezes, os padres provinciais e procuradores faziam encomendas de

\footnotetext{
${ }^{262}$ SEPP, Antônio. Viagem às Missões Jesuíticas e Trabalhos apostólicos [Introdução e notas de Wolfgang Hoffmann Harnisch; tradução de Reymundo Schneider e dos alunos da Companhia de Jesus, em Pareci] São Paulo: Martins, Edusp, 1972. p. 73.

263 Ibidem, p. 9.

${ }^{264}$ Ibidem, p. 90.
} 
instrumentos por preços altíssimos, mesmo sem ter certeza da qualidade dos mesmos:

Pode-se avaliar o alto conceito em que a música é tida aqui no Paraguai pelo fato de o Procurador, que veio conosco, ter comprado nos Países-Baixos um órgão para Buenos Aires, o qual custou mil Talers, e que antes ele nunca vira e que ainda nem chegou ao Paraguai, de modo que não se sabe se o instrumento presta alguma coisa ou não. Da mesma forma comprou-me ele diversos instrumentos de música na Espanha, entre eles uma espineta, um clavicórdio, uma trompa marinha e várias charamelas. Eram horrivelmente caros, cotados com preços alemães, apesar disso não valem nada. ${ }^{265}$

Evidente, porém, que as compras efetuadas não eram suficientes para suprir toda a Província. É neste cenário que o desenvolvimento de oficinas destinadas à produção de instrumentos musicais ganhou enorme importância. Assim, a fama de Yapeyú como polo musical das reduções vinha não só pela formação musical oferecida aos indígenas, mas também por ser o povoamento um grande fabricante de instrumentos musicais.

\subsection{Fabricação de instrumentos}

Antônio Sepp não só ensinou os indígenas a tocar instrumentos como também a construí-los. Um dos principais motivos que alavancaram esta atividade foi, certamente, a dificuldade em conseguir instrumentos produzidos na Europa. $\mathrm{O}$ alto custo desta operação, além do longo tempo de espera e o risco de que partes se deteriorassem na turbulenta travessia, fez com que a produção local se tornasse uma opção e uma necessidade. Era preciso suprir o crescente número de músicos com uma quantidade de instrumentos bem maior do que a que dispunham os jesuítas.

Sepp é considerado por diversos pesquisadores como um pioneiro no desenvolvimento da luthiería nas missões. ${ }^{266}$ De forma paralela às suas classes de música, o missionário criou oficinas para a fabricação de instrumentos. E de maneira semelhante aos especialistas em cada instrumento, mestres no fabrico destas peças também começaram a aparecer: "Temos dois órgãos, um dois quais trazidos da

\footnotetext{
265 SEPP, Antônio. Viagem às Missões Jesuíticas e Trabalhos apostólicos [Introdução e notas de Wolfgang Hoffmann Harnisch; tradução de Reymundo Schneider e dos alunos da Companhia de Jesus, em Pareci] São Paulo: Martins, Edusp, 1972. pp. 75-76.

266 SZARÁn, Luis; NESTOSA, Jose. Música en las Reducciones Jesuíticas de América Del Sur. $2^{\mathrm{a}}$ Edición. Asunción: Missionsprokur, 1999. pp. 77-78.
} 
Europa, ao passo que o outro foi feito pelos índios, e tão semelhantes, que a princípio eu mesmo me enganei e levei o órgão indígena por conta do europeu." ${ }^{267}$ Mais uma vez a habilidade imitativa dos nativos recebe destaque. A partir de modelos oferecidos pelos jesuítas (o próprio padre Sepp trouxe alguns instrumentos da Europa), os indígenas produziam cópias, desenvolvendo assim a fabricação destes objetos na missão de Yapeyú. Além disso, a produção abastecia não só a própria redução, como também era exportada para outras missões e até mesmo para as cidades coloniais espanholas. ${ }^{268} \mathrm{E}$ a variedade era grande:

(...) o órgão, as violas da gamba em seus diversos tamanhos, os violinos, bombardas, chirimias, dulcianas, flautas, harpas, guitarras e vihuelas (antepassado do violão), alaúdes, trompetes, trompas e tambores. Todos os instrumentos, de fabricação muito cuidada, saíam das oficinas guaranis. ${ }^{269}$

Quando já se encontrava à frente da redução de São João Batista, Sepp descobriria o processo de obtenção de ferro através de uma rocha bastante comum na região, trazendo novo ânimo ao processo de fabricação de instrumentos. Como vimos no capítulo anterior, a produção de ferro e aço da redução era bastante incipiente para abastecer a Província e seu processo de obtenção era bastante trabalhoso. No entanto, se pensarmos neste procedimento voltado não para a fabricação de ferramentas em larga escala, mas para a fundição de sinos, para a produção de determinados instrumentos, como trompetes e trombas, ou mesmo partes deles, como tubos de órgãos, a obtenção de ferro em âmbito local deveria oferecer uma excelente alternativa para a falta de materiais. Vale lembrar que Antônio Sepp, durante sua estada em Yapeyú, recebeu ordens de construir um órgão para a redução e, devido à falta de ferro necessário à tarefa, teve de improvisar os tubos do instrumento utilizando tábuas de cedro desbastadas. ${ }^{270}$ Outras improvisações são relatadas, como cítaras feitas de casca de tartaruga. Por mais dificultosa que fosse, a produção de ferro em São João Batista deve ter aumentado as possibilidades de fabrico de instrumentos

\footnotetext{
${ }^{267}$ SEPP, Antônio. Viagem às Missões Jesuíticas e Trabalhos apostólicos [Introdução e notas de Wolfgang Hoffmann Harnisch; tradução de Reymundo Schneider e dos alunos da Companhia de Jesus, em Pareci] São Paulo: Martins, Edusp, 1972. p. 82.

${ }^{268}$ FURLONG apud RABUSKE, Arthur S.J. Pe. Antônio Sepp, SJ - O Gênio das Reduções Guaranis. 3.ed. São Leopoldo: Editora Unisinos, 2003. p. 123.

${ }^{269}$ PREISS, Jorge Hirt. A música nas missões jesuíticas nos séculos XVII e XVIII. Porto Alegre: Martins Livreiro Editor, 1988. pp. 21-27. Esta publicação conta com diversas ilustrações dos instrumentos utilizados e fabricados nas missões.

${ }^{270}$ SEPP, op. cit., pp. 117-18.
} 
musicais. Tudo era válido para suprir as demandas e garantir que a música estivesse presente nas cerimônias e no cotidiano das missões.

\subsection{Instrumento de Celebração}

Guillermo Wilde apresenta uma interessante divisão das variadas celebrações que ocorriam no ambiente missioneiro. Para o antropólogo, uma classificação bastante pertinente destes acontecimentos é a que os divide de acordo com sua frequência: cotidianos, anuais e ocasiões especiais, sendo que de cada categoria surgem funções bastante claras. ${ }^{271}$ Antônio Sepp mais uma vez se apresenta como personagem privilegiado para o estudo deste universo já que em suas cartas relata celebrações que exemplificam as três divisões propostas por Wilde. Em cada uma delas, a presença e a importância de sonoridades fica evidente.

Entre as cerimônias diárias, ou cotidianas, destacam-se as missas, sempre acompanhadas de música. Nas descrições de Sepp, elas aparecem como um elemento organizador da vida diária das reduções, ajudando a definir uma ordem temporal: "Todos os sábados temos missa cantada de Nossa Senhora e ladainha. Todos os domingos missa cantada e sermão. Meus músicos tocam música todos os dias durante a Santa Missa, e isto, graças a Deus, de maneira bem aceitável." 272 Os sinos chamam os neófitos para a missa, que ocorre ao raiar do dia, e é após seu término que cada indígena se dirige às suas tarefas.

As cerimônias anuais, por sua vez, rompiam com a rotina, com o cotidiano. Vinculavam-se ao calendário litúrgico e aos dias de santos, especialmente aos padroeiros de cada missão. Somam-se a estas datas eventos "civis", como a eleição dos cabildos. Guillermo Wilde os enxerga como de extrema importância por seu significado político e econômico, pois contribuíam com a redefinição de relações sociais:

Eran los contextos propicios para que la sociedad se representase

\footnotetext{
${ }^{271}$ WILDE, Guillermo. Poderes del ritual y rituales del poder: un análisis de las celebraciones en los pueblos jesuíticos de Guaraníes. In: Revista Española de Antropologia Americana. n. 33. 2003. p. 207. Disponível em: http://www.google.com.br/search?q=guillermo+wilde+poderes+del+ritual\&ie=utf-8\&oe=utf8\&aq=t\&rls=org.mozilla:en-US:official\&client=firefox-a\&gfe_rd=cr\&ei=RvARUifCMai8wfN0oDoAQ. Acesso em: 01/03/2014.

${ }^{272}$ SEPP, Antônio. Viagem às Missões Jesuíticas e Trabalhos apostólicos [Introdução e notas de Wolfgang Hoffmann Harnisch; tradução de Reymundo Schneider e dos alunos da Companhia de Jesus, em Pareci] São Paulo: Martins, Edusp, 1972. p. 72.
} 
a sí misma mostrando sus jerarquías y, simultáneamente, creando condiciones para el reajuste de cuentas e intercambios reciprocitarios entre los actores (entre jefes, entre miembros de cacicazgo, entre unos y outros, entre ambos sectores y los jesuítas). ${ }^{273}$

O capítulo XXXIV de Trabalhos apostólicos exemplifica bem estas festividades. Intitulado $\mathrm{Na}$ celebração das festas, introduzem-se danças que muito divertem aos indígenas, ${ }^{274}$ apresenta descrições que nos permitem diferenciar estes acontecimentos daqueles rotineiros. Sepp afirma que era costume em toda a Espanha haver dança nas festas mais solenes e que, portanto, ele providenciara que o mesmo se fizesse em sua redução, São João Batista. Após detalhar o ritual religioso e toda a preparação envolvida, diz:

Findando o ofício solene, [os indígenas] exibem coros e danças no vestíbulo da igreja. Durante isto, os índios principais ou caciques tomam assento ou de um ou de outro lado, como em anfiteatro. Já é a dança pírrica (dança de espadas), já a de argolas, já a corrida troiana pedestre ou equestre. (...) Além disto, procurei suscitar sentimentos de piedade em nossos índios por meio de cenas teatrais acomodadas a esta gente rude. (...) Nem, tão pouco, careceu o drama de um prólogo e de música (...). ${ }^{275}$

Estes eventos, voltados para o rompimento da rotina, eram marcados por diversas apresentações ensaiadas, além da tradicional missa. Tudo, conforme nos indica Sepp, com muita música. Peças teatrais eram encenadas tendo por tema a vida dos santos, danças ocorriam dentro e fora do espaço das igrejas, tomando as ruas e a praça da redução.

Por isso, em todos os dias de festa, depois das vésperas e antes da missa solene, vestimos de maneira sobremodo bonita alguns rapazotes indígenas, tão bonito como os pobres índios nunca o viram. Então, na igreja, onde tudo está reunido, executam suas danças. Também por ensejo de procissões públicas costumamos apresentar danças, principalmente na festa do Corpo de Deus,

\footnotetext{
${ }^{273}$ WILDE, Guillermo. Poderes del ritual y rituales del poder: un análisis de las celebraciones en los pueblos jesuíticos de Guaraníes. In: Revista Española de Antropologia Americana. n. 33. 2003. p. 209. Disponível em: http://www.google.com.br/search?q=guillermo+wilde+poderes+del+ritual \&ie=utf-8\&oe=utf$8 \& \mathrm{aq}=\mathrm{t} \& \mathrm{rls}=$ org.mozilla:en-US:official\&client=firefox-a\&gfe_rd=cr\&ei=RvARUifCMai8wfNOoDoAQ. Acesso em: 01/03/2014.

${ }^{274}$ SEPP, Antônio. Viagem às Missões Jesuíticas e Trabalhos apostólicos [Introdução e notas de Wolfgang Hoffmann Harnisch; tradução de Reymundo Schneider e dos alunos da Companhia de Jesus, em Pareci] São Paulo: Martins, Edusp, 1972. pp. 180-181.

275 Ibidem.
} 
quando alguns dançam diante do Santíssimo. ${ }^{276}$

Em paralelo com o excerto de Wilde, visto acima, nota-se que os caciques, agora membros do cabildo, assumiam posições privilegiadas nestas celebrações. Desde o local em que se colocavam até as vestes que utilizavam, existia a preocupação em afirmar sua importância naquela sociedade. E estes eventos, que reuniam toda a comunidade em acontecimentos que fugiam da rotina, propiciavam a visibilidade de uma hierarquia pela participação diferenciada de seus atores no cerimonial.

Já o terceiro tipo de celebrações, as especiais, abarcavam inúmeros acontecimentos de relevância para um ou mais povoados, sem uma periodicidade específica: visitas de padres provinciais, bispos, governadores, fundação de uma nova redução, celebração de uma colheita próspera etc. Wilde acrescenta ainda casamentos, batizados e funerais, mesmo estes acontecendo de forma bastante regular e previsível. Para ele, o que diferencia estas celebrações é seu potencial de formação de uma memória coletiva:

Ellas introducen en este ámbito un nuevo régimen de temporalidad, el de la "historia" entendida en un sentido lineal, es decir, el acontecimiento irrepetible. (...) A partir de la misma, los acontecimientos irrepetibles pueden ser revividos mediante su recuerdo y puesta en escena ceremonial. ${ }^{277}$

Neste escopo, vários são os exemplos presentes nas descrições do padre Sepp. O primeiro deles relaciona-se ao início de suas atividades nas reduções, ou seja, a recepção realizada pelo povoamento de Yapeyú aos missionários recém-chegados. E mesmo dias antes de avistarem a redução, durante a jornada em jangadas rio Uruguai acima, Antônio Sepp relata o encontro caloroso com o inaciano responsável pela missão de Santa Cruz, desejoso de ser o primeiro a dar-lhes as boas-vindas. Importante notar que o que garantia a pompa desta recepção era a presença de índios músicos:

\footnotetext{
${ }^{276}$ SEPP, Antônio. Viagem às Missões Jesuíticas e Trabalhos apostólicos [Introdução e notas de Wolfgang Hoffmann Harnisch; tradução de Reymundo Schneider e dos alunos da Companhia de Jesus, em Pareci] São Paulo: Martins, Edusp, 1972. p. 91.

277 WILDE, Guillermo. Poderes del ritual y rituales del poder: un análisis de las celebraciones en los pueblos jesuíticos de Guaraníes. In: Revista Española de Antropologia Americana. n. 33. 2003. p. $210 . \quad$ Disponível em: http://www.google.com.br/search?q=guillermo+wilde+poderes+del+ritual\&ie=utf-8\&oe=utf$8 \& \mathrm{aq}=\mathrm{t} \& \mathrm{rls}=$ org.mozilla:en-US:official\&client=firefox-a\&gfe_rd=cr\&ei=RvARUifCMai8wfN0oDoAQ. Acesso em: 01/03/2014.
} 
Hoje, dia 25, veio ao nosso encontro, rio abaixo, o Padre José Seravia, da redução Santa-Cruz. Trouxe consigo vinte músicos, que tocavam música sobre diversos tipos de instrumentos, para, em nome de todas as reduções, nos receber e nos acompanhar entre júbilo e alegria na nossa entrada na Terra Prometida. ${ }^{278}$

Já em Yapeyú, a recepção contou com diversas apresentações de dança, exercícios militares, além de missas solenes dando graças pela chegada dos novos inacianos. Assim como nas festas anuais, o papel de distinção dos corregedores fica evidente:

Então os músicos entoaram o Laudate Dominum omnes gentes, e o "Louvai ao Senhor todos os povos" foi cantado em reconhecimento devido ao Supremo Deus, por se haver, mais uma vez, compadecido destes pobres povos, enviando tantos curas de almas (...). Terminado o 'Laudate', veio o corregedor - é assim que chamam em espanhol o mais distinto dos indígenas - e nos fez um pequeno discurso de agradecimento, dando-nos as boas-vindas em nome de todo o povo. ${ }^{279}$

E não só as cerimônias de recepção estão presentes nos relatos do jesuíta. Sepp, ao iniciar a busca de terras para a fundação da redução de São João Batista, descreve que a partida da delegação a cavalo, que contava com a presença dos principais caciques do povoado de São Miguel, deu-se com todo um cerimonial, em que "retumbavam as trombetas, tímpanos e flautas." 280 E nas cerimônias fúnebres, durante o cortejo, "em lugar de lamentações fúnebres, os músicos cantam um péã vitorioso, convidando os jovens e as donzelas a louvarem a Deus."281

O ponto central aqui é que os padres jesuítas fizeram amplo uso da música e de outros recursos sonoros nas mais diversas celebrações, fossem elas cotidianas ou especiais. A cada ofício executado nas missões eram reservados certos cânticos, os quais mudavam os conteúdos e tons, a fim de comover em um sentido ou outro, isto é, atemorizar, dar esperanças, levar à sensação de culpa e necessidade de redenção. Em ocasiões especiais, como procissões ou recepção a padres visitadores, assim como durante as missas e outros ofícios religiosos, os músicos e os membros do coral eram

\footnotetext{
${ }^{278}$ SEPP, Antônio. Viagem às Missões Jesuíticas e Trabalhos apostólicos [Introdução e notas de Wolfgang Hoffmann Harnisch; tradução de Reymundo Schneider e dos alunos da Companhia de Jesus, em Pareci] São Paulo: Martins, Edusp, 1972. p. 56.

${ }^{279}$ Ibidem, pp. 60-61.

${ }^{280}$ Ibidem, p. 139.

${ }^{281}$ Ibidem, p. 179.
} 
posicionados de maneira estratégica, acompanhando os pregadores, nos momentos solicitados, com suas vozes e instrumentos tocados:

Se disponían coros en el lugar donde se celebraban los actos y sermones, que actuaban en momentos determinados, reforzando así las palabras del predicador, dándoles mayor dramatismo. En ocasiones, el tono era trágico, en otras más dulce, de acuerdo con la naturaleza de la "función" misional en cuestión (....). ${ }^{282}$

As cerimônias, como práticas correntes no contexto das reduções, tiveram na música seu mais importante suporte e potencializador. Em alternância com o trabalho, definiam o ritmo da vida social.

\subsection{Instrumento de regência temporal e laboral}

Ao passarem de estruturas de organização tribais para espaços urbanos de molde europeu, os ameríndios sofreram profundas transformações em seu modo de vida e na forma de enxergar o universo a sua volta. Não só suas moradias sofreram grandes transformações, mas, de forma ainda mais profunda, sua estrutura familiar e a própria noção de tempo ${ }^{283}$ Os neófitos, que até então estavam acostumados com outra relação tempo/espaço (posição do sol, fases da lua, plantios e colheitas, incursões contra grupos inimigos, rituais de iniciação etc.) passaram a basear-se no rígido sistema temporal introduzido pelos missionários:

El panorama sonoro de los pueblos se vio completamente transformado: a los sonidos de las campanas que marcaban un nuevo ritmo de vida y una nueva concepción del tiempo, se unieron los sonidos de los cantos e instrumentos de la tradición musical europea. ${ }^{284}$

Nas missões, o som se revela como parte de uma tentativa de controle jesuítico sobre os atos, o espaço e o tempo dos índios. Como vimos acima, os sinos da igreja anunciavam o início de mais um dia, convidando os indígenas à missa. Lá, cantos

${ }^{282}$ RICO CALLADO, Francisco Luis. Conversión y persuasión en el barroco: propuestas para el estúdio de las misiones interiores en la España postridentina. In: Studia histórica. Historia moderna, 24, Ediciones Universidad de Salamanca, 2002. p. 379.

283 ZERON, Carlos. "Mission et espace missionnaire: les bases matérielles de la conversion". In: Archives des Siences Sociales des Religions. Paris: édtions EHESS, nº 169, janvier-mars 2015, p. 307-334.

${ }^{284}$ RODRÍGUEZ, Diana Farley. Y Dios se hizo música: La conquista musical del Nuevo Reino de Granada. In: Fronteras de La Historia. Universidad Nacional de Colômbia. Vol. 15-1 / 2010. pp. 13-38. 
acompanhados de instrumentos diversos buscavam encantar os novos cristãos ao mesmo tempo em que iam, aos poucos, incutindo a liturgia católica em suas vidas. Após a missa, músicos seguiam os trabalhadores às lidas nos ervais e pastos, onde passavam todo o dia, até serem novamente chamados pelos sinos para retornarem à redução, participarem de outras obrigações religiosas e recolherem-se. Segundo relata Cardiel:

La distribuición cuotidiana es ésta: a las 4 en verano, se toca a levantar. A las 5 en invierno. A las 4 y media en otoño y primavera. A las 4 y media toca la campana de la torre à las Avemarías: á las 4 y media é oración mental. (...) A las 5 y media, á salir de oración con la campana chica de los Padres, y con de la torre, á Misa. (...) á las dos se toca la campana grande á vísperas. (...) A las 5, á rezar los muchachos, y pregúntales la Doctrina un Padre: acabada ésta, toca la campana grande al rosario, viene el pueblo, y reza á coros, asistiendo los Padres. Al fin se dice el Acto de contrición y cantan los músicos el Bendito y alabado, respondiendo todo el pueblo á cada cláusula, un día en su lengua y otro dia en castellano. (...) Después á su lección espiritual, etc. hasta cenar, á que se toca á las 7 en verano y á las 8 en invierno; (...) De suerte que en todo el día se toca once veces la campana de los Padres á todas las distribuciones que en los colegios, lo que se practica puntualmente. ${ }^{285}$

A estrutura missioneira implementada pelos jesuítas introduziu uma nova percepção de tempo aos indígenas reduzidos. Esta nova temporalidade, contínua e racionalizada, era passível de ser medida, controlada. Era intimamente ligada com as novas relações de trabalho, pois o controle do tempo, da duração dos processos de produção, permitia o acúmulo de excedentes. Este modelo visava substituir as formas tradicionais de trabalho indígena, baseadas na descontinuidade, e mesmo eliminá-las inteiramente, no decorrer das gerações. Isso porque esta ordem, definida pelo costume, reforçada cotidianamente, acabava por sedimentar-se com o passar dos anos, tornando-se "natural".

Aqui, a estratégia hegemônica era converter as noções de tempo e trabalho em sinônimos. ${ }^{286}$ Cardiel, ao discorrer sobre os nomes dados pelos indígenas aos dias da semana:

${ }^{285}$ CARDIEL, José. Breve relación de las misiones del Paraguay. Buenos Aires: Theoria, 1994. (1771). pp. 94-95.

${ }^{286}$ WILDE, Guillermo. Poderes del ritual y rituales del poder: un análisis de las celebraciones en los pueblos jesuíticos de Guaraníes. In: Revista Española de Antropologia Americana. n. 33. 2003. p. $208 . \quad$ Disponível em: http://www.google.com.br/search?q=guillermo+wilde+poderes+del+ritual \&ie=utf- $8 \&$ oe $=$ utf$8 \& \mathrm{aq}=\mathrm{t} \& \mathrm{rls}=$ org.mozilla:en-US:official\&client=firefox-a\&gfe_rd=cr\&ei=RvARUifCMai8wfN0oDoAQ. Acesso em: 01/03/2014. 
(...) llaman al lunes mbae apoipi, trabajo primero. Al martes mbae apomocoi: trabajo segundo. Al jueves trique, entrada, porque al principio no sólo entraban a la iglesia a Catecismo el domingo, sino también el jueves. Al sábado, llaman víspera de fiesta, y al domingo fiesta. Y lo que las personas mayores rezan en el templo, lo rezan al mismo tiempo niños y niñas, aquellos en el patio y éstas en el cementerio. Luego entran a misa y sérmon. ${ }^{287}$

Os músicos cumpriam importante papel neste sistema. Eles participavam das mais variadas atividades econômicas, como é visto na implementação das plantações de algodão em São João Batista, por volta de 1702:

Antes de ser lançada a semente à terra, os meus músicos, que são os mais sagazes de todos, primeiro estendem cordéis longitudinal e transversalmente. No lugar onde ambas as linhas se cruzam é lançada a semente. ${ }^{288}$

Também marcavam presença no levantamento do número de cabeças de gado das reduções. No documento sobre a disputa envolvendo as missões de São Miguel e São Luís, lemos:

Ynforme de la cantidad i numero de Bacas q trajo el Pe. Joan de Yegros personalmente el año de 98, q fueron cuarenta i dois mil Bacas contadas por el Pe. Joan i 4 Cantores q fueron a la Baquería i do los dos Capitanes de las tropas, q saben contar por exercício g. ${ }^{\text {de }} \mathrm{i}$ continuado q na tenido siempre. ${ }^{289}$

Antônio Sepp também relata a participação de índios músicos neste tipo de atividade: "(...) hoje se nutrem 50.000 vacas (tantas contou hoje, enquanto escrevo isto, o meu músico e procurador; e isto somente nas pastagens de minha redução, sem

${ }^{287}$ CARDIEL apud WILDE, Guillermo. Poderes del ritual y rituales del poder: un análisis de las celebraciones en los pueblos jesuíticos de Guaraníes. In: Revista Española de Antropologia Americana. n. 33. 2003. p. 208. Disponível em: $\mathrm{http}: / / \mathrm{www} \cdot$ google.com.br/search?q=guillermo+wilde+poderes+del+ritual $\&$ ie $=$ utf- $8 \&$ oe $=$ utf$8 \& \mathrm{aq}=\mathrm{t} \& \mathrm{rls}=$ org.mozilla:en-US:official\&client=firefox-a\&gfe_rd=cr\&ei=RvARUifCMai8wfN0oDoAQ. Acesso em: 01/03/2014.

${ }^{288}$ SEPP, Antônio. Viagem às Missões Jesuíticas e Trabalhos apostólicos [Introdução e notas de Wolfgang Hoffmann Harnisch; tradução de Reymundo Schneider e dos alunos da Companhia de Jesus, em Pareci] São Paulo: Martins, Edusp, 1972. p. 148.

${ }^{289}$ Informe do Pe. Francisco de Avendaño da redução de São Luís contra o padre Antônio Ximenes da redução de São Miguel, o qual se dizia lesado por aquela nas vacas de sua estância. Acervo da Biblioteca Nacional, Rio de Janeiro. In: Manuscritos da Coleção De Angelis, vol. 5. pp. 104-110. Disponível 
contar os terneiros que nasceram este ano, pois que cada vaca dá cria uma vez por ano) (...)." ${ }^{290} \mathrm{O}$ ritmo musical ajudava a controlar o ritmo do trabalho, como podemos observar com os índios remadores: “(...) cada canoa tinha seu tambor, um pífaro e uma trombeta. Estes tinham que fazer música. Isto confortava os remeiros indígenas (...). ${ }^{, 291}$

Nos esforços para a construção de São João Batista, terras precisavam ser preparadas, habitações precisavam ser erguidas e o material para tanto precisava ser recolhido. As tarefas ocorriam com ritmo marcado: "Era de ver-se aqui cinquenta bois, acolá outros cinquenta, entrar no povoado, puxando em alongadíssimo trajeto a mole de um enorme cedro, tudo em belíssima ordem, ao som do tambor e dos bárbaros clamores da bugrada." ${ }^{292}$ Este procedimento perduraria mesmo após a desestruturação das missões.

A historiadora Daniela Ribeiro Pereira apresenta, em sua dissertação de mestrado, um reporte do Tenente Governador Gonzalo de Doblas, um dos administradores nomeados para os povos após a expulsão. Neste interessante documento, de 1758, Doblas relata o apreço dos indígenas pela música e, o que é mais interessante para nós, a negativa dos índios para o trabalho caso não houvesse o acompanhamento de músicos. ${ }^{293}$

Trata-se de uma noção funcional do tempo e das práticas musicais, já que ligada à regularização de atividades religiosas, econômicas e sociais. Este dado, aparentemente inocente, reflete uma parte importante da estrutura política das reduções, desde o início um modelo racional de organização social, e mesmo da visão de mundo dos missionários jesuítas.

Vale lembrar que estudos teóricos sobre a música como uma linguagem matematicamente harmônica eram base de complexos teoremas filosóficos surgidos no decorrer do século XVII e que resgatavam a tradição antiga de pensadores como Pitágoras (c. 570 - c. 496 a.c.) e seus cálculos sobre a frequência dos sons das liras

\footnotetext{
${ }^{290}$ SEPP, Antônio. Viagem às Missões Jesuíticas e Trabalhos apostólicos [Introdução e notas de Wolfgang Hoffmann Harnisch; tradução de Reymundo Schneider e dos alunos da Companhia de Jesus, em Pareci] São Paulo: Martins, Edusp, 1972. p. 146.

${ }^{291}$ Ibidem, p. 58.

${ }^{292}$ Ibidem, p. 156.

${ }^{293}$ PEREIRA, D. R. "Si soy misionero es porque canto, bailo y toco música": para uma história social da música na Provincia Paracuaria (1680-1768). 2011. 164f. Dissertação de Mestrado. PUCRS, Porto Alegre. 2011. p. 93. Disponível em: http://tede.pucrs.br/tde_busca/arquivo.php?codArquivo=3678. Acesso em: 15/04/2015.
} 
gregas $^{294}$, em conformidade com a ortodoxia católica.

Em sua enciclopédia musical Musurgia Universalis $(1650)^{295}$, o jesuíta alemão Athanasius Kircher (1601-1680) produziu não só um dos textos musicais mais importantes do período, mas um verdadeiro retrato filosófico de como o mundo era entendido em seu tempo. Kircher, que não era músico, possuía a visão essencialmente medieval de que o cosmos era revelado em relações musicais e que a harmonia musical espelhava a harmonia de Deus. ${ }^{296}$

Embora este inaciano tenha vivido e trabalhado no Collegio Romano durante a maior parte de sua vida, é muito provável que Antônio Sepp tenha tido contato com sua obra. Musurgia Universalis foi dedicada ao então arquiduque austríaco Leopoldo. Como vimos no capítulo anterior, este viria a se tornar imperador do Sacro Império Romano-Germânico e daria grande impulso ao desenvolvimento musical. Se levarmos em conta que Sepp cresceu em meio a este cenário de florescimento cultural, tendo sido escolhido pelo próprio imperador para juntar-se ao coral dos meninos cantores da corte de Viena, não é difícil imaginar que o jovem músico tenha lido a obra de Kircher e que este trabalho tenha influenciado sua formação musical e religiosa, inclusive refletindo em suas ações como missionário.

Esta suposição baseia-se nos próprios atos do Padre Sepp, que buscava a todo custo manter a estrutura da missão funcionando sem ruídos ou dissonâncias. Estes poderiam comprometer não só as atividades temporais, mas a salvação das almas. $\mathrm{O}$ andamento de cada tarefa era vistoriado para manter o todo em sintonia e o ritmo do trabalho era, como vimos nos excertos do jesuíta, acompanhado pelo ritmo musical. Tudo era pensado de maneira a garantir um funcionamento harmônico, "para maior glória de Deus".

\subsection{Instrumento de diferenciação social}

O antropólogo Maurice Godelier afirma que para que novas formas de

\footnotetext{
${ }^{294}$ Cf. CHAUÍ, Marilena. Introdução à história da filosofia, v.1: Dos pré-socráticos a Aristóteles. São Paulo: Companhia das Letras, 2007, pp. 64-79.

${ }^{295}$ KIRCHER, Athanasius S.J. Musurgia universalis sive ars magna consoni et dissoni in X. libros digesta. Romae: Ex typographia Haeredum F. Corbellitti, 1650. 2v. Disponível em: http://imslp.org/wiki/Musurgia_Universalis_(Kircher,_Athanasius). Acesso em: 10/06/2015.

${ }^{296}$ EGGINGTON, Tim. Athanasius Kircher, Musurgia universalis, 1650. In: University of Reading Library Special Collections. Reading: Univerity of Reading. 2007. Disponível em: https://www.reading.ac.uk/web/FILES/special-collections/featurekircher.pdf. Acesso em: $10 / 06 / 2015$.
} 
dominação se desenvolvam, com a aceitação e até mesmo cooperação dos dominados, torna-se necessária uma nova divisão das ocupações, implicando em uma especialização e hierarquização de alguns grupos sociais encarregados de funções que aparentemente trazem benefícios a toda a comunidade, o que legitima sua posição. ${ }^{297}$ É este o caso dos índios músicos.

Sabemos que as práticas musicais tiveram papel de destaque na organização espiritual e temporal das missões jesuíticas. Ofícios atrelados a atividades religiosas, como fabricantes de instrumentos, copistas, cantores, instrumentistas, dançarinos etc., detinham maior prestígio dentre as atividades técnicas nas missões. Os músicos teriam inclusive posição de destaque nos cabildos. Segundo Wilde: “La 'burocracia' cabildante se dividía entre los encargados de controlar las faenas colectivas ('los que mandan') y la gente de 'oficios y artesanía' ('los que conocen')."298 Para Jacqueline Ahlert:

Os artesãos estavam inseridos numa categoria com distinção, ainda que não organizada de maneira homogênea. Poderiam ser selecionados entre filhos de caciques, ou, também, escolhidos pelos jesuítas conforme demonstrassem talento e aptidões. Eram introduzidos no ofício das artes e das letras, no entalhe e na policromia da madeira, na música, na confecção de instrumentos, entre outras atividades. ${ }^{299}$

$\mathrm{Na}$ introdução à edição em espanhol das cartas de Sepp, Hoffmann assinala que: "La mayoria de los índios que no tienen un oficio como músico u operário de los talleres, trabaja en el campo". ${ }^{300}$ Tudo isso comporta uma diferenciação de um grupo em relação ao restante dos indígenas da redução. Os músicos, como pudemos observar através da narrativa de Antônio Sepp, participavam ativamente da organização de eventos e atividades dentro e fora das reduções. Eles estavam sempre

297 GODELIER, Maurice. Lo ideal y lo material: Pensamiento, economías, sociedades. Versión castellana de A. J. Desmont. Madrid. Taurus Humanidades, 1989. Título original: L'ídéel et le matériel (1984). p. 32.

${ }^{298}$ WILDE, Guillermo. Poderes del ritual y rituales del poder: un análisis de las celebraciones en los pueblos jesuíticos de Guaraníes. In: Revista Española de Antropologia Americana. n. 33. 2003. p. $213 . \quad$ Disponível em: http://www.google.com.br/search?q=guillermo+wilde+poderes+del+ritual\&ie=utf-8\&oe=utf$8 \& \mathrm{aq}=\mathrm{t} \& \mathrm{rls}=$ org.mozilla:en-US:official\&client=firefox-a\&gfe_rd=cr\&ei=RvARUifCMai8wfN0oDoAQ. Acesso em: 01/03/2014.

${ }^{299}$ AHLERT, Jacqueline. Amálgamas culturais e representações imagéticas nas doutrinas da Província Jesuítica do Paraguai. In: Sæculum - Revista de História [28]; João Pessoa, jan./jun. 2013. pp. 7172. Disponível em: http://periodicos.ufpb.br/ojs/index.php/srh/article/view/18189. Acesso em: $10 / 04 / 2015$

${ }^{300}$ HOFFMAN, Werner. Introducción. In: SEPP, Antonio. Relación de viaje a las misiones jesuíticas. Buenos Aires: EUDEBA, 1971. p. 95. 
presentes em atividades agrícolas, pecuárias, entre diversas outras. E isto se dava por suas capacidades técnicas. Na publicação Jardín de flores paracuario, Antônio Sepp discorre longamente sobre as habilidades dos músicos indígenas:

Los músicos son los más hábiles: no sólo tocan algunos de ellos todos los instrumentos, y no solamente uno o dos como los músicos alemanes, sino que también funden campanas cuyo sonido es tan sonoro como el de las campanas de Nola en Campania, fabrican relojes de campana parecidos a los de Augsburgo, órganos, clarines, pífanos y flautas, chirimías, fagotes, arpas, laúdes violines (...). ${ }^{301}$

Ao abordamos a vida do padre Sepp, nos referimos ao momento em que o jesuíta se viu em meio a uma grande epidemia de varíola na região das missões, tendo que atuar em diversas delas na tentativa de combater a doença e tratar dos enfermos: "O padre precisa tomar o pulso aos pacientes, precisa fazer a sangria, porque isto só poucos índios sabem fazer." 302 Em certo momento, o inaciano decidiu realizar uma sangria em toda a população de sua redução. Porém, como sabia ser impossível realizar tal procedimento sozinho, a tarefa recaiu sobre os índios músicos, provavelmente estes "poucos que sabem fazer":

Mas perguntará aqui o leitor curioso: Quem cortou a veia de tantos índios de ambos os sexos e quem fez o papel de cirurgião? Quem arranjou, com tal penúria de ferro, tantas lancetas para o Pe. Antônio? Escute o leitor benévolo e explua em risotas sufocadas. (...) Os meus músicos e ferreiros abriam as veias, ou melhor, espicaçavam miseravelmente a pele com canivetes e, à falta de utensílios cortantes, com pregos. Pois como poderia ser que o índio, com a mesma faca com que matara e esfolara o touro, ferisse serenamente o braço, para extrair sangue? Os próprios músicos foram os primeiros a fazer a experiência em si mesmos, sujeitandose a esta operação e prestando um ao outro este benefício. Aos cantores seguiram os ferreiros, e logo todo o povo (...). ${ }^{303}$

\footnotetext{
${ }^{301}$ SEPP, Antônio. Jardín de flores paracuario. Buenos Aires: EUDEBA, 1974. p. 179.

302 SEPP, Antônio. Viagem às Missões Jesuíticas e Trabalhos apostólicos [Introdução e notas de Wolfgang Hoffmann Harnisch; tradução de Reymundo Schneider e dos alunos da Companhia de Jesus, em Pareci] São Paulo: Martins, Edusp, 1972. p. 66.

${ }^{303}$ Ibidem, pp. 122-23. Neste trecho, nota-se uma diferença considerável entre as traduções em português e espanhol: "No faltará aquí un lector curioso que desee saber quén hacía la sangria a tantos miles de indios de ambos sexos y quién había conseguido los instrumentos necesarios, tanto más en Paracuaria donde hierro y acero son tan preciosos como en otras partes el oro y la plata. mis músicos y mozos de fragua, de los que tenía muchos, podrán contestar esta pregunta. Como erán más hábiles que la chusma y el hombre común, abrían las venas con sus cuchillos, o si no los tenían, con clavos de hierro y a falta de éstos con huesos puntiagudos, más vale decir, agujereaban, desollaban y maltrataban la piel. (...) Estos mismos músicos y mozos de fragua que fueron encargados de la cruel sangría, habían tenido que empezar con la empresa aventurada en ellos mismos, sangrándose mutuamente.” SEPP, Antonio. Relación de viaje a las misiones jesuíticas. Buenos Aires: EUDEBA, 1971. p. 151.
} 
Ainda com relação às aptidões diferenciadas, quando da disputa acerca das cabeças de gado entre as reduções de São Miguel e São Luís, quem contou o número de vacas existentes nas estâncias foram "quatro cantores q han sido Procuradores aqui I ejerçitados en el contar." 304 Nota-se, então, que as habilidades técnicas dos índios músicos faziam com que também fossem utilizados em outras funções que não a musical. Daniela Ribeiro Pereira afirma que "o músico missioneiro não recebeu todo o reconhecimento e papel de destaque em suas reduções por seus dotes artísticos, mas por suas habilidades técnicas." 305 No mesmo sentido, Jacqueline Ahlert diz que não era raro nas oficinas haver índios mestres em diversos ofícios. ${ }^{306}$

Antônio Sepp nos apresenta alguns índios cujas habilidades em variadas atividades admiravam-no. É o caso de Inácio Paica ou Gabriel Quiri. Estes indígenas eram, ao mesmo tempo, músicos talentosos, luthiers, construtores de armas e relógios, ourives e habilidosos fundidores. O missionário ainda atesta que "Inácio Paica não é o único Apolo na trípode. Em cada redução se pode topar com um ou mais campeões destes, mestres em todos os ofícios mecânicos e exímios maestros de música." ${ }^{307}$ Ora, o adjetivo "campeões" nos permite supor que havia um desejo de galgar posições.

Se pensarmos que havia cerca de meia centena de ameríndios, em cada redução, capaz de executar música de maneira a atender os missionários nas mais diversas situações; se imaginarmos o tempo despendido pelos jesuítas na formação destes profissionais e se recordarmos que havia milhares de outros trabalhadores indígenas, cujos ofícios englobavam um número muito maior de indivíduos passíveis de recrutamento para o trabalho nas terras da redução ou de colonos, é possível inferir que os padres da Companhia de certa forma protegeriam seus músicos, o que

${ }^{304}$ Informe do Pe. Francisco de Avendaño da redução de São Luís contra o padre Antônio Ximenes da redução de São Miguel, o qual se dizia lesado por aquela nas vacas de sua estância. Acervo da Biblioteca Nacional, Rio de Janeiro. In: Manuscritos da Coleção De Angelis, vol. 5. pp. 104-110. Disponível http://objdigital.bn.br/acervo_digital/div_manuscritos/mss1019246/mss1019246.pdf. Acesso em: 10/03/2014. p. 108. Optamos por manter a mesma grafia encontrada na documentação.

305 PEREIRA, D. R. "Si soy misionero es porque canto, bailo y toco música": para uma história social da música na Provincia Paracuaria (1680-1768). 2011. 164f. Dissertação de Mestrado. PUCRS, Porto Alegre. 2011. p. 131. Disponível em: http://tede.pucrs.br/tde_busca/arquivo.php?codArquivo=3678. Acesso em: 15/04/2015.

${ }^{306}$ AHLERT, Jacqueline. Amálgamas culturais e representações imagéticas nas doutrinas da Província Jesuítica do Paraguai. In: Sæculum - Revista de História [28]; João Pessoa, jan./jun. 2013. p. 72. Disponível em: http://periodicos.ufpb.br/ojs/index.php/srh/article/view/18189. Acesso em: 10/04/2015.

307 SEPP, Antônio. Viagem às Missões Jesuíticas e Trabalhos apostólicos [Introdução e notas de Wolfgang Hoffmann Harnisch; tradução de Reymundo Schneider e dos alunos da Companhia de Jesus, em Pareci] São Paulo: Martins, Edusp, 1972. p. 185. 
explicaria sua "liberação" das encomiendas. Daniela Ribeiro Pereira afirma que devemos enxergar na vontade dos indígenas em dominar as práticas musicais introduzidas pelos jesuítas uma 'forma de ascender socialmente e 'se livrar' de um trabalho compulsório que não se adequava à realidade pregressa dessas populações." 308 Ou seja, um meio de tornarem-se "campeões".

Partindo destas constatações, não é nada forçado crer que os músicos das missões tivessem ciência de sua posição e dos benefícios que seu ofício lhes proporcionava. Natural também é imaginar que os indígenas que possuíam ofícios que apresentassem condições mais desgastantes, como colhedores de erva-mate, ${ }^{309}$ por exemplo, passassem a perceber as vantagens obtidas por seus irmãos músicos e começassem a enxergar as práticas musicais não mais somente como uma forma de contato com o sagrado, mas também como um instrumento de ascensão social dentro do contexto em que agora se achavam inseridos.

Além disso, não é forçado imaginar que os neófitos não se revoltavam com os privilégios assegurados a estes músicos pois os encaravam como legítimos, já que estes especialistas desempenhavam funções que beneficiavam o grupo de forma muito mais significativa do que eram beneficiados (através, por exemplo, do sustento proveniente do trabalho alheio). Afinal, eram os músicos que auxiliavam no contato de todos com o sagrado, além de garantirem ao mesmo tempo a ressignificação e a apropriação das novas práticas em vista de suas práticas ancestrais. A massa de trabalhadores do campo deveria sentir-se em dívida com os músicos, por tudo que estes lhes proporcionavam. Jacqueline Ahlert, ao trabalhar o papel de destaque assumido pelos artesãos neste contexto, afirma:

No caso dos pintores e escultores, davam forma aos santos, que seriam venerados no cotidiano da redução. O chamado artesano mayor manejava o sagrado. Por suas mãos, rudes pedaços de madeira se transformavam em belas imagens da Virgem, de Cristo e

308 PEREIRA, D. R. "Si soy misionero es porque canto, bailo y toco música": para uma história social da música na Provincia Paracuaria (1680-1768). 2011. 164f. Dissertação de Mestrado. PUCRS, Porto Alegre. 2011. p. 130. Disponível em: http://tede.pucrs.br/tde_busca/arquivo.php?codArquivo=3678. Acesso em: 15/04/2015.

${ }^{309}$ Testimonio de los guaraníes de San Ignacio (Paraná), 14 de agosto de 1630. In: Testimonios, cartas y manifiestos indígenas (desde la conquista hasta comienzos del siglo XX). Selección, prólogo, notas, glosario y bibliografía de Martin Lienhard. Caracas: Biblioteca Ayacucho, 1992, p. 311-315. Disponível http://bibliotecayacucho.gob.ve/fba/index.php?id=97\&backPID=103\&begin_at=112\&tt_products= 181. Acesso em: 20/02/2015. 
dos santos. Era, assim, investido de certo carisma e dignidade. ${ }^{310}$

Os músicos, assim como os artesãos de uma forma mais geral, tinham papel importantíssimo nos rituais religiosos das reduções. Eram eles que preenchiam os espaços missioneiros de sons, pinturas, esculturas, fundamentais para a assimilação de elementos culturais exógenos e, consequentemente, para o processo catequético dos jesuítas.

Por seus talentos, estes músicos passaram a ser requisitados até mesmo fora das reduções. Segundo Horacio Bollini: "durante toda la experiencia jesuítica los músicos guaraníes serán requeridos en las ciudades del ámbito colonial, y el brillo de sus actuaciones - considerado inusual para el entonces salvaje horizonte rioplatense sería recordado por largo tiempo." ${ }^{311}$

Sendo parte essencial do cerimonial, passaram a ser vigiados de forma rigorosa. Isto porque era necessário que estes especialistas se portassem de acordo com a importância de suas funções. Para este controle comportamental, além de uma regulamentação da circulação destes indígenas, foram criadas regras, como aquelas presentes no Reglamento General de Doctrina, de 1689. Nele, o Artigo 38 apresenta interessantes apontamentos:

Haya especial vigilancia en que los Congregantes de Nuestra Señora e Cantores, que más inmediatamente sirven al altar, vivan virtuosa y honestamente. $\mathrm{Y}$ si dieren escándalo, y castigados y corregidos algunas veces no se emendaren los echarán de la Congregación o Música; sin que vuelvan a ella sin orden del Superior, que con notable enmienda la podrá dar; y si aconteciere que algún indio Maestro vaya á alguna Reducción nueva, sea de conocida virtud, á elección del mismo Superior; y si diere mal ejemplo, lo volverá a su pueblo (sin aguardar más) el Padre que cuida de la Reducción. ${ }^{312}$

Já o Artigo 14 demonstra uma clara necessidade de regulamentação das

\footnotetext{
${ }^{310}$ AHLERT, Jacqueline. Amálgamas culturais e representações imagéticas nas doutrinas da Província Jesuítica do Paraguai. In: Sæculum - Revista de História [28]; João Pessoa, jan./jun. 2013. p. 72. Disponível em: http://periodicos.ufpb.br/ojs/index.php/srh/article/view/18189. Acesso em: 10/04/2015.

${ }^{311}$ BOLLINI, Horacio. Arte en las Misiones Jesuíticas: Los espejos del Mundo Jesuítico-Guaraní. Buenos Aires: Corregidor, 2007. p. 192.

${ }^{312}$ Reglamento General de Doctrinas Enviado por el provincial P. Tomás Donvidas, y aprobado por el general P. Tirso. 1689. Ordenes para todas las Reducciones, aprobados por N. P. General. In: HERNÁNDEZ, Pablo. Organización Social de las Doctrinas Guaraníes de la Compañia de Jesús. Tomo I. Barcelona: Gustavo Gili, 1911. p. 596. Disponível em: http://bdhrd.bne.es/viewer.vm?id=0000012629\&page=1. Acessado em 01/05/2014.
} 
celebrações e, devido ao aumento das populações e do número de missões, como no caso da fundação de São João Batista a partir da divisão de São Miguel, da circulação entre as reduções:

En el celebrar las fiestas, las Doctrinas de Loreto, Corpus y San Ignacio se corresponderán entre si y no con otras. Las de Santa Ana, Candelaria y Itapúa se corresponderán entre si y no con otras. San Nicolás, San Luis y San Miguel se corresponderán entre sí y no con otras. Asimismo Santo Tomé y San Borja se corresponderán entre si y no con otras: y lo mismo La Cruz y Yapeyú. ${ }^{313}$

Além disso, o documento também deixa transparecer certa cautela quanto ao aumento do número de músicos. O Artigo 22 determina que "Los cantores en ninguna Doctrina pasarán de cuarenta; y procúrese minorar ese número, especialemente en los pueblos pequeños". ${ }^{314} \mathrm{O}$ padre Cardiel faz coro ao Reglamento quando discorre sobre Antônio Sepp e o período em que atuou como missionário:"Hay orden de los Superiores de que no pasen de cuarenta, para que no hagan falta al gobierno económico del pueblo".315 Daniela Ribeiro Pereira afirma que além de uma normatização da prática musical, estas instruções explicitam a preocupação dos inacianos com o fato de que os neófitos prefeririam a formação em ofícios artísticos, o que acarretaria uma perda na mão de obra de vacarias, ervais etc. ${ }^{316}$

No entanto, o próprio padre Sepp nos dá indícios de que esta regra não era seguida à risca. Ao relatar a recepção em Buenos Aires, destinada a ele e aos outros padres vindos da Europa, afirma: "Sessenta músicos, com toda espécie de cornos, pífaros e charamelas americanos, vieram ao nosso encontro para receber-nos (...)." 317 Em outro momento, ao apelar para que seus mestres de música dos colégios da Companhia lhe enviassem partituras, o missionário afirma que não pede só em seu

\footnotetext{
${ }^{313}$ Reglamento General de Doctrinas Enviado por el provincial P. Tomás Donvidas, y aprobado por el general P. Tirso. 1689. Ordenes para todas las Reducciones, aprobados por N. P. General. In: HERNÁNDEZ, Pablo. Organización Social de las Doctrinas Guaraníes de la Compañia de Jesús. Tomo I. Barcelona: Gustavo Gili, 1911. p. 594. Disponível em: http://bdhrd.bne.es/viewer.vm?id=0000012629\&page=1. Acessado em 01/05/2014.

${ }^{314}$ Ibidem.

${ }^{315}$ CARDIEL apud FURLONG, Guillermo S.J. José Cardiel y Su Carta Relación. Libreria del rio de la Plata. Buenos Aires, 1953. p. 164.

316 PEREIRA, D. R. "Si soy misionero es porque canto, bailo y toco música": para uma história social da música na Provincia Paracuaria (1680-1768). 2011. 164f. Dissertação de Mestrado. PUCRS, Porto Alegre. 2011. p. 82. Disponível em: http://tede.pucrs.br/tde_busca/arquivo.php?codArquivo=3678. Acesso em: 15/04/2015.

${ }^{317}$ SEPP, Antônio. Viagem às Missões Jesuíticas e Trabalhos apostólicos [Introdução e notas de Wolfgang Hoffmann Harnisch; tradução de Reymundo Schneider e dos alunos da Companhia de Jesus, em Pareci] São Paulo: Martins, Edusp, 1972. p. 9.
} 
nome, "mas no de todos os pobres músicos indígenas, os quais, se se reunir aos de todas as reduções, somam uns 3.000 homens." 318

Se lembrarmos que no apogeu do projeto missionário da Companhia de Jesus junto à Província Paracuaria, entre 1735 e 1750, esta contava com 30 reduções, caso o regulamento fosse rigidamente seguido teríamos em torno de 1200 índios músicos, menos da metade do que Antonio Sepp afirma existir na época de sua chegada. De qualquer forma, se levássemos em conta a seleção de 100 indivíduos em uma população como a da redução de São João Batista, que no ano de 1715 contava com 3.025 almas, ${ }^{319}$ ainda ficaria evidente a presença de um grupo bastante restrito dentre os milhares de indígenas reduzidos.

E a importância deste grupo restrito reflete em sua posição privilegiada dentro da hierarquia social missioneira. Em sua Breve Relación de las misiones del Paraguay, o padre Cardiel salienta a proeminência dos músicos em momentos chave de afirmação de poder dentro da missão. É o caso das cerimônias de nomeação dos representantes do povoamento. Nelas, os músicos têm papel central não só no andamento da celebração, como recebem destaque político, assim como o corregedor:

(...) se junta todo el pueblo delante del pórtico de la Iglesia antes de Misa. En él ponen los sacristanes una silla ordinaria para el Cura, una gran mesa al lado, donde se ponde el bastón del Corregidor, las varas de los Alcaldes y todas las demás insignias de los Cabildantes, y también ponen el compás del maestro de música, que es una banderilla de seda, las llaves de la puerta de la Iglesia (...). Acabada esta exhortación, nombra el Corregidor, y luego los músicos con sus chirimías y clarines celebran la elección con un corta tocata, pero alegre. Nombra los Alcaldes, y hacen lo mismo los músicos (...). Acabados de nombrar todos los del Cabildo, nombra los que pertenecen à la Iglesia: sacristán, maestro de Capilla, etc. y otros jefes de otros oficios políticos y económicos: y ultimamente los de la milicia. Y después entra la Misa con toda la solemnidad. ${ }^{320}$

A encenação descrita por Cardiel demonstra que entre os símbolos representativos do poder político nas reduções, estava "el compás del maestro de música". A distinção deste grupo com relação ao restante da população, e até mesmo

\footnotetext{
${ }^{318}$ SEPP, Antônio. Viagem às Missões Jesuíticas e Trabalhos apostólicos [Introdução e notas de Wolfgang Hoffmann Harnisch; tradução de Reymundo Schneider e dos alunos da Companhia de Jesus, em Pareci] São Paulo: Martins, Edusp, 1972. p. 72.

${ }^{319}$ Estado De Las Reducciones De Los Ríos Parana Y Uruguay En El Año 1715. 31/12/1715. ARAGN.DE/CJ. Fondo Jesuíta Digital. Sala IX (410-229-695). División Colonia.

${ }^{320}$ CARDIEL, José. Breve relación de las misiones del Paraguay. Buenos Aires: Theoria, 1994. (1771). pp. 46-47. Grifo nosso.
} 
de outros especialistas técnicos, torna-se evidente. Os músicos seriam, então, membros privilegiados da comunidade missioneira, isentos de trabalhos comunais mais pesados e favorecidos em diversas situações. Seriam membros de uma elite, cujo poder baseava-se em seu conhecimento, suas habilidades técnicas e nos serviços prestados à comunidade. 


\section{CONSIDERAÇÕES FINAIS}

Ser musico era ser más.

Bartomeu Melià S. J.

Para que seja possível estudar a utilização da música nas missões jesuíticas da Província Paracuaria é necessário analisar as várias dimensões que acompanham suas práticas: as regras estabelecidas pela Ordem e as adaptações às quais foram sujeitas, os atores (indígenas e missionários), os cenários, a materialidade, bem como as funções com as quais foi utilizada. Foi a partir desta constatação que escolhemos analisar a vida e as atividades do jesuíta Antônio Sepp.

A Companhia de Jesus sempre se preocupou com o registro de sua própria história, legando aos pesquisadores interessados em sua atuação um gigantesco acervo documental. A partir das cartas e relatórios de missionários, provinciais e superiores inacianos, inúmeros assuntos podem ser abordados. É necessário, porém, um olhar atento para estas fontes, que na maior parte das vezes apresentam a voz de apenas um lado, o dos próprios jesuítas. É preciso buscar nos textos aquilo que eles não dizem. Daniela Ribeiro Pereira afirma que não é mais o ineditismo das fontes que enriquece a investigação, mas sim os diversos olhares e metodologias sob os quais elas são interpretadas. $^{321}$ Desta forma, foi essencial partir de estudos já realizados sobre Antônio Sepp, sobre música nas missões e sobre sua estrutura, para apreender as mais variadas abordagens, sempre atentando ao caráter laudatório de muitas delas, mas sem nos prendermos à mera crítica, que deixa de lado contribuições importantes.

Há na Companhia um grande desejo por uniformidade e, ao mesmo tempo, existe uma grande quantidade e variedade de experiências, como pudemos observar pelos escritos de Sepp, Cardiel e Avendaño. Embora o que transpareça nos relatos seja em grande medida a voz da instituição, demonstrando a submissão e obediência do "irmão em Cristo" à uniformidade pregada pela Companhia de Jesus, é possível nos utilizarmos destas correspondências na tentativa de perscrutar elementos que ajudem a entender melhor determinados personagens históricos e o cenário que envolvia suas ações, como foi o caso do jesuíta Antônio Sepp.

A trajetória deste missionário tirolês é significativa ao permitir a abordagem

\footnotetext{
${ }^{321}$ PEREIRA, D. R. "Si soy misionero es porque canto, bailo y toco música": para uma história social da música na Provincia Paracuaria (1680-1768). 2011. 164f. Dissertação de Mestrado. PUCRS, Porto Alegre. 2011. p. 54. Disponível em: http://tede.pucrs.br/tde_busca/arquivo.php?codArquivo=3678. Acesso em: 15/04/2015.
} 
de diversos aspectos que fundamentam as práticas musicais missioneiras, além da própria dinâmica organizacional das reduções. A formação musical em um ambiente de pleno florescimento cultural refletiu-se em sua predisposição para a renovação da música executada nas missões. Da mesma forma, sua exaustiva preparação teológica e filosófica nos colégios da Companhia de Jesus garantiu que as práticas musicais fossem vistas como importante instrumento pedagógico e catequético.

Mas não só de aspectos espirituais caracterizou-se a formação de Sepp. A praticidade necessária para a organização de estruturas tão complexas quanto as reduções americanas fazia com que os candidatos às "vinhas paraguaias" fossem treinados em ofícios diversos, adquirindo habilidades técnicas que viriam a ser fundamentais em seus trabalhos no novo continente. É o caso de Antônio Sepp, sua atuação como docente, a preparação em Sevilha e em diversos colégios da Ordem, e o desenvolvimento que imprimiu à luthieria, à fundição de metais, à criação de gado, às culturas agrícolas e ao tratamento de moléstias nas missões americanas.

O Padre Sepp e a música andaram sempre lado a lado e, através da análise de ambos, pudemos apresentar aspectos que consideramos relevantes para o contexto missioneiro. A importância e escassez de ferro para o abastecimento da província foi abordada em paralelo com o desenvolvimento de oficinas para a construção de instrumentos musicais. A criação de gado serviu para explicitar a presença da música na organização e tutela do trabalho, assim como para jogar luzes sobre a divisão de tarefas e o destaque obtido por músicos e por mestres artesãos.

Ainda no que tange aos aspectos estruturais ligados às práticas musicais, a relação entre as missões, envolvendo circulação de saberes e mercadorias foi vista pelo viés do ensino musical. Por fim, as celebrações religiosas, repletas de sonoridades, ajudaram na abordagem de uma nova noção de tempo introduzida pelos jesuítas e paulatinamente assimilada pelos indígenas reduzidos. Em termos gerais, vimos como o cerimonial instituía uma ordem baseada em noções funcionais de uma ideologia que buscava se tornar dominante. Que ao mesmo tempo em que tentava naturalizar mudanças no modo de ser e encarar o mundo dos índios, canalizava e incorporava tradições nativas, operando uma síntese.

Neste sentido, o estudo da música nas missões exige uma compreensão cada vez maior da diversidade e complexidade das culturas com as quais missionários e colonos se depararam. A interdisciplinaridade mostra-se essencial nesta tarefa, buscando luzes na Antropologia, Arqueologia, Geografia e História com o objetivo de 
esclarecer melhor os elementos culturais dos povos guaranis e possibilitar a reconstrução de um cenário mais elaborado deste período, que não analise o contato através de um único viés, o europeu, predominante em decorrência das fontes escritas. Como vimos, as etnografias modernas nos ajudam a complementar, ou ao menos comparar as informações advindas de documentos administrativos ou de relatos de jesuítas e viajantes. Buscamos absorver algumas das contribuições resultantes destas discussões, explicitando pontos que atestam a possibilidade de diálogo entre Antropologia e História no estudo do período colonial americano, em específico o estudo do contato entre jesuítas e ameríndios em terras paraguaias. Procuramos, desta forma, explicitar certos aspectos que atestam a importância da música para estes indígenas e que suscitam a reflexão sobre a forma como encararam as novas sonoridades geradas pelo contexto missioneiro.

Pensar em como se formam e se reproduzem sociedades é um ponto de partida extremamente frutífero para a análise das estruturas de funcionamento das mesmas. No caso específico das missões jesuíticas, não se pode crer que a organização de um sistema complexo envolvendo culturas tão diversas baseou-se no uso da força, em métodos coercitivos visando a submissão dos nativos aos colonizadores europeus, entre eles os missionários jesuítas. Godelier ajuda-nos a refletir sobre a impossibilidade de manutenção de uma sociedade, qualquer que seja ela, baseada apenas na violência. Segundo ele, não há possibilidade de reprodução de uma sociedade apenas porque existe uma força opressora que obriga os indivíduos a agir de determinada maneira. Assim, as relações sociais predominariam quando funcionassem ao mesmo tempo como relações sociais de produção, como marco e sustento social do processo material de apropriação da natureza. ${ }^{322}$

O consentimento aparece, então, como contraponto essencial, também constituinte do poder de dominação dos homens sobre os homens. A ideia de que as pessoas aderem voluntariamente a sistemas de opressão joga luzes sobre alguns aspectos de difícil compreensão na estrutura missioneira. Como um padre, sozinho, conseguiu colocar em um certo regime de trabalho e organização espacial milhares de indígenas? Embora a questão permaneça sem respostas, em grande parte devido à falta de documentação sobre o período, pudemos, através dos pontos apresentados no decorrer deste trabalho, apresentar algumas hipóteses.

322 GODELIER, Maurice. Lo ideal y lo material: Pensamiento, economías, sociedades. Versión castellana de A. J. Desmont. Madrid. Taurus Humanidades, 1989. Título original: L'ídéel et le matériel (1984). p. 40. 
Acreditamos que a adesão voluntária a um sistema que no fim das contas é explorador e opressor pode ter muito mais responsabilidade na formação, funcionamento e reprodução da estrutura reducional do que a malícia do índio, que buscava se aproveitar da situação sempre que possível. A ideia de ver a resistência como uma esperteza, uma negociação em que os indígenas tiram vantagens, ou resistem se adaptando, advém do debate recente em torno da construção de uma história indígena, da busca de agência indígena que se oponha a simples passividade perante a dominação colonial. Evidente que tal agência existiu, que formas de resistência existiram. Mas não podemos nos restringir a isso. Existiu um consentimento voluntário que se manifestou de diversas maneiras, como por exemplo a obediência às leis e o respeito a determinadas figuras e instâncias simbólicas, possibilitando a incorporação da estrutura opressora pelos próprios oprimidos, ou dominados, e garantindo a reprodução desta sociedade e a manutenção do poder dos dominantes.

Para Godelier, a única forma de explicar como indivíduos e grupos dominados, geralmente em número bem maior do que os dominantes, consentem "espontaneamente" com sua dominação baseia-se na ideia de que tal dominação deve ser encarada como uma troca de serviços entre as partes envolvidas. Mais do que isso, torna-se necessário que ambas as partes compartilhem as mesmas representações para que surja "la fuerza más fuerte del poder de los unos sobre los otros, el consentimiento basado en el reconocimiento de los beneficios, de la legitimidad y de la necesidad de ese poder." ${ }^{323}$

Para o antropólogo francês, foi necessário que as respostas para os novos problemas, advindos do surgimento de novas relações sociais, hierarquizadas, parecessem vantajosas para todos, principalmente para aqueles que sofreriam os aspectos negativos de tal mudança. Em nosso caso, os indígenas reduzidos. Diz Godelier:

Fue menester, pues, que se produjera, no una ciega conjunción de deseos perversos, sino una comunidad de pensamiento, una gran compartición en las mismas representaciones, para que se lograse la adhesión del mayor número posible, y que su

${ }^{323}$ GODELIER, Maurice. Lo ideal y lo material: Pensamiento, economías, sociedades. Versión castellana de A. J. Desmont. Madrid. Taurus Humanidades, 1989. Título original: L'ídéel et le matériel (1984). pp. 187-188. 
pensamiento y su voluntad contribuyeran a la producción y la reproducción de nuevas divisiones de la sociedad que alteraban profundamente el ejercicio de la dominación del hombre por el hombre. ${ }^{324}$

A música desempenha papel fundamental neste contexto. A divisão de tarefas e hierarquização social surgidas no universo missioneiro colocaram em destaque aqueles cujas habilidades técnicas lhes garantiu privilégios frente ao restante do grupo. E dentre estes hábeis especialistas, os músicos despontavam como membros detentores de um poder transcendental: o domínio sobre a música. Música de extrema importância ritualística tanto para indígenas quanto para missionários, instrumento que permitia a conexão com instâncias divinas.

Esta nova música, trazida da Europa pelos jesuítas e posteriormente renovada por Antônio Sepp, foi difundida pelas reduções e, no decorrer das décadas, apropriada pelos indígenas reduzidos, cujas culturas pregressas já viam nas práticas musicais um instrumento de poder. Estes índios se apoderaram desta ferramenta de destaque religioso, político e social (instâncias divididas na cultura ocidental, mas não na ameríndia) e, lentamente, transformaram seu potencial em algo que pudesse ser utilizado a seu favor.

Em uma sociedade hierarquizada como a missioneira, com divisão de funções de trabalho, o acesso ao sagrado ficava centralizado na figura do jesuíta, que contava com o auxílio de grupos específicos, como o dos músicos. Godelier afirma que para que as novas formas de dominação se desenvolvam, com a aceitação e até mesmo cooperação dos dominados, torna-se necessária uma nova divisão das ocupações, implicando em uma especialização e hierarquização de alguns grupos sociais encarregados de funções que aparentemente trazem benefícios a toda a comunidade. Entre elas, destaca os serviços "mágico-religiosos destinados al control ritual de una naturaleza qua va siendo progresivamente domesticada por el hombre." ${ }^{325}$ Como vimos, a música era presença essencial em rituais tanto indígenas quanto missioneiros, dado seu poder transcendente de se comunicar com instâncias sagradas, sendo os músicos os responsáveis por manter essa relação em funcionamento.

\footnotetext{
324 GODELIER, Maurice. Lo ideal y lo material: Pensamiento, economías, sociedades. Versión castellana de A. J. Desmont. Madrid. Taurus Humanidades, 1989. Título original: L'ídéel et le matériel (1984). p. 32.

${ }^{325}$ Ibidem.
} 
O papel destes profissionais no cerimonial, baseado em seu conhecimento e suas habilidades técnicas, assegurava que seus privilégios não fossem contestados por seus irmãos, já que ao executarem suas obrigações estavam trazendo benefícios a toda a comunidade, o que legitimava sua posição. Os indígenas reduzidos estariam eternamente em dívida não só com o missionário, mas também com os músicos. Por mais que os neófitos produzissem excedentes para o abastecimento da redução, permitindo trocas de produtos com outras missões ou com colonos, nada compensava o fato de que o jesuíta salvou suas almas do inferno e de que possuía contato privilegiado com o sagrado, comunicação esta garantida pela atuação dos músicos.

E por saberem bem do papel de destaque destes especialistas, os jesuítas valeram-se de regulamentos na tentativa de restringir o número de indígenas com acesso a este instrumento de diferenciação que era a música, buscando também garantir que este grupo social se portasse de acordo com a importância da atividade que exercia. Não só a regulamentação da prática musical era importante, mas também a representação e o comportamento dos músicos perante o restante da população.

Portanto, a música foi vista pelos missionários jesuítas como instrumento essencial no contato com aqueles que buscavam converter, transformar, gerenciar, encontrando em suas práticas ferramentas importantes para garantir um funcionamento harmônico das reduções. Por outro lado, os indígenas reduzidos enxergaram a música missioneira não só como uma aproximação possível, pois já conhecida como elemento de sua cultura; também viram nela uma possibilidade de ascensão social dentro de um contexto inteiramente novo que se apresentava a eles. 


\title{
REFERÊNCIAS
}

\author{
$\underline{\text { Fontes Impressas }}$
}

CARDIEL, José. Breve relación de las misiones del Paraguay. Buenos Aires: Theoria, 1994. (1771)

CONSTITUIÇÕES da Companhia de Jesus e Normas Complementares. São Paulo: Edições Loyola, 2004. (1558). Disponível em: http://books.google.com.br/books?id=TF3d94YuJYoC\&printsec $=$ frontcover\&hl=p $\mathrm{t}-\mathrm{BR} \&$ source $=\mathrm{gbs} \_\mathrm{ge} \_$summary_r$\& \mathrm{cad}=0 \# \mathrm{v}=$ onepage $\& \mathrm{q} \& \mathrm{f}=$ false. Acesso em: $11 / 05 / 2015$.

Informe do Pe. Francisco de Avendaño da redução de São Luís contra o padre Antônio Ximenes da redução de São Miguel, o qual se dizia lesado por aquela nas vacas de sua estância. Acervo da Biblioteca Nacional, Rio de Janeiro. In: Manuscritos da Coleção De Angelis, vol. 5. pp. 104-110. Disponível em: http://objdigital.bn.br/acervo_digital/div_manuscritos/mss 1019246/mss 1019246.pd f. Acesso em: 10/03/2014.

LOZANO, Pedro S. J. Necrológio do P. Antônio Sepp S. J. In: RABUSKE, Arthur. Pe. Antônio Sepp, SJ - O Gênio das Reduções Guaranis. $2^{a}$ edição, São Leopoldo: Editora Unisinos, 1979.

Reglamento General de Doctrinas enviado por el Provincial P. Tomás Donvidas, y aprobado por El General P. Tirso. 1689. Ordenes para todas las Reducciones aprobados por N. P. General. In: HERNÁNDEZ, Pablo. Organización Social de las Doctrinas Guaraníes de la Compañia de Jesús. Barcelona: Gustavo Gili, 1911. Disponível em: http://www.archive.org/details/organizacinsocia01hern. Acesso em: 01/05/2014.

SEPP, Anthony. An account of a voyage from Spain to Paraquaria; Performed by the Reverend Fathers, Anthony Sepp and Anthony Behme, Both German Jesuits, The First of Tyrol upon the River Eth, he Other of Bavaria. Containing a Description of all the remarkable Things, and the Inhabitants, as well as of the Missionaires refinding in that Country. Taken [...] Translated from the High Dutch Original. London: printed for A \& J. Churchill. 1704. Disponível em: https://archive.org/details/accountofvoyagef00sepp. Acesso em: 13/07/2013.

SEPP, Antonio. Relación de viaje a las misiones jesuíticas. Buenos Aires: EUDEBA, 1971.

SEPP, Antônio. Viagem às Missões Jesuíticas e Trabalhos apostólicos [Introdução e notas de Wolfgang Hoffmann Harnisch; tradução de Reymundo Schneider e dos alunos da Companhia de Jesus, em Pareci] São Paulo: Martins, Edusp, 1972.

Jardín de flores paracuario. Buenos Aires: EUDEBA, 1974

Algumas instruções relativas ao governo temporal das reduções em suas fábricas, sementeiras, estâncias e outras fainas. In: RABUSKE, Arthur - Pe. Antônio Sepp, SJ - O Gênio das Reduções Guaranis. 2. ed. São Leopoldo: Editora Unisinos, 1979.

Carta latina de 13 de junho de 1714. In: RABUSKE, Arthur - Pe. Antônio

Sepp, SJ - O Gênio das Reduções Guaranis. 3. ed. São Leopoldo: Editora Unisinos, 2003.

Testimonio de los guaraníes de San Ignacio (Paraná), 14 de agosto de 1630. In:

Testimonios, cartas y manifiestos indígenas (desde la conquista hasta comienzos del siglo XX). Selección, prólogo, notas, glosario y bibliografía de 
Martin Lienhard. Caracas: Biblioteca Ayacucho, 1992, p. 311-315. Disponível em: http://bibliotecayacucho.gob.ve/fba/index.php?id=97\&backPID=103\&begin_at=11 2\&tt_products=181. Acesso em: 20/02/2015.

\section{Archivo General de la Nación Argentina}

Carta Del Padre Antonio Sepp Al Padre Procurador De Misiones Thomas Verle Sobre Liquidación De Cuentas De Establecimientos De La Compañía De Jesús. 18/10/1731. AR-AGN.DE/CJ. Fondo Jesuíta Digital. Sala IX (411-409696). División Colonia.

Copia De La Sentencia Dada Por El Padre Pablo Restivo A Favor Del Pueblo De La Concepcion, Como Consecuencia Del Pleito Que Mantenía Dicho Pueblo Con El De San Xavier Por La Posesión De Yerbatales. 09/12/1697. ARAGN.DE/CJ. Fondo Jesuíta Digital. Sala IX (409-121-694). División Colonia.

Declaración Del Padre Francisco Ximenez Acerca De Las Vaquerías Realizadas Por Los Indios En Las Zonas De Misiones. 03/06/1706. AR-AGN.DE/CJ. Fondo Jesuíta Digital. Sala IX (410-8-695). División Colonia.

Estado De Las Reducciones De Los Ríos Parana Y Uruguay En El Año 1715. 31/12/1715. AR-AGN.DE/CJ. Fondo Jesuíta Digital. Sala IX (410-229-695). División Colonia.

Memorial Del Padre Provincial Ignacio De Arteaga Para EI Pueblo De La Cruz. 31/07/1727. AR-AGN.DE/CJ. Fondo Jesuíta Digital. Sala IX (411-260-696). División Colonia.

Memorial Del Padre Viceprovincial Luys De La Roca Para El Padre Superior Del Pueblo De La Cruz. 25/05/1714. AR-AGN.DE/CJ. Fondo Jesuíta Digital. Sala IX (410-174-695). División Colonia.

Testimonio De Pedido Del Padre Anselmo De La Mata De Despacho De Hierro A Las Reducciones De Indios De La Compañía De Jesús. A Continuación, Confirmación Del Despacho Solicitado. 12/04/1691. AR-AGN.DE/CJ. Fondo Jesuíta Digital. Sala IX. División Colonia.

\section{Bibliografia Complementar:}

AGNOLIN, Adone. O governo das almas indígenas: missão jesuítica e ritualidade indígena (séc. XVI-XVII). In: SOUZA, Laura de Mello e; FURTADO, Júnia Ferreira; BICALHO, Maria Fernanda (orgs.) O governo dos povos. São Paulo: Alameda, 2009.

AHLERT, Jacqueline. Amálgamas culturais e representações imagéticas nas doutrinas da Província Jesuítica do Paraguai. In: Sæculum - Revista de História [28]; João Pessoa, jan./jun. 2013. pp. 67-81. Disponível em: http://periodicos.ufpb.br/ojs/index.php/srh/article/view/18189. Acesso em: 10/04/2015.

BOLLINI, Horacio. Arte en las Misiones Jesuíticas: Los espejos del Mundo Jesuítico-Guaraní. Buenos Aires: Corregidor, 2007.

Misiones Jesuíticas - visión artística y patrimonial: Voces y emblemas en las reducciones jesuítico-guaraníes: 1609-1768. Buenos Aires: Corregidor, 2009.

BRANDÃO, H. H. N. Estudos sobre o discurso. Tese (Livre Docência). FFLCHUSP, São Paulo, 2001.

BRAUMANN, Francisco. 3.000 Guaraníes y un Tirolés: Reducciones guaraníticas Sepp Von Rainegg (1655-1733). Tradução: José Gallinger. Buenos Aires. Editorial 
Guadalupe. 1981. Título do original alemão: 3000 Indianer und ein Tiroler. Verlag St. Gabriel Steyer Verlag, 1977.

CARDOZO, Efraím. Historiografía Paraguaya. Tomo I. México: Instituto Panamericano de Geografia e Historia, 1959.

CASTAGNA, P. A. Cantochão e liturgia: implicações na pesquisa da música católica latino-americana (séculos XVI-XX). In: IV SIMPÓSIO LATINO-AMERICANO DE MUSICOLOGIA, Curitiba, 20-23 jan. 2000. Anais. Curitiba, Fundação Cultural Curitiba, 2001a, p. 199-222.

Estilo antigo e estilo moderno na música antiga latino-americana. In:

Apostila do curso História da Música Brasileira. São Paulo, Instituto de Artes da Unesp, 2004. Disponível em: http://www.ia.unesp.br/Home/AreadoAluno/HMB_2004_apostila05.pdf. Acesso em: 04/03/2014.

- Alma Latina: música das Américas sob domínio europeu - I [texto dos programas 1 a 4]. Revista Portuguesa de História do Livro. v. 29-30, p. 627654, 2012.

CESARINO, P.N. De duplos e estereoscópios: paralelismo e personificação nos cantos xamanísticos ameríndios. In: Mana. 12 (1): 105-134. 2006. Disponível em: http://www.scielo.br/scielo.php?script=sci_arttext\&pid=S0104-

93132006000100004. Acessado em: 20/10/2014.

CHAUÍ, Marilena. Introdução à história da filosofia, v.1: Dos pré-socráticos a Aristóteles. São Paulo: Companhia das Letras, 2007.

DAVIDSON, N. S. A Contra-Reforma. São Paulo: Editora Martins Fontes, 1991.

EDVINSSON, Rodney. Foreign exchange rates in Sweden 1658-1803. In: Stockholm Papers in Economy History [8]; Stockholm, may 2009. Disponível em: http://historia.se/SPEH8.pdf. Acesso em: 15/05/2015.

EGGINGTON, Tim. Athanasius Kircher, Musurgia universalis, 1650. In: University of Reading Library Special Collections. Reading: Univerity of Reading. 2007. Disponível em: https://www.reading.ac.uk/web/FILES/specialcollections/featurekircher.pdf. Acesso em: 10/06/2015.

EISENBERG, José. As missões jesuíticas e o pensamento político moderno: encontros culturais, aventuras teóricas. Belo Horizonte: Ed. UFMG, 2000.

FABRE, Pierre-Antoine; VINCENT, Bernard (dir.). Missions religieuses modernes "notre lieu est le monde". Rome: École française de Rome, 2007. 410p. Collection de l'École française de Rome 376.

FERNANDES, Florestan. Antecedentes indígenas: organização social das tribos tupis. In: HOLANDA, S. B.; CAMPOS, P. M., Orgs. Historia Geral da Civilização Brasileira - A Época Colonial: do Descobrimento a Expansão Territorial. Rio de Janeiro: Bertrand Brasil, 1989. v.1 t.1.

FLECK, Eliane. Sobre martírios e curas: medicina e edificação nas reduções jesuíticoguaranis. In: Estudos Ibero-Americanos. PUCRS, v.XXXI, n. 1, pp. 35-50, junho de 2005.2 Disponível em: http://revistaseletronicas.pucrs.br/iberoamericana/ojs/index.php/iberoamericana/art icle/viewFile/1324/1029. Acesso em: 15/04/ 2015.

FOCKING, G. F. A História das Missões Orientais do Uruguai e a memória nacional. In: XXVII Simpósio Nacional de História - Conhecimento histórico e diálogo social. Natal, 22 a 26 de julho de 2013. Disponível em: http://snh2013.anpuh.org/resources/anais/27/1364743174_ARQUIVO_Gabriel_Fo cking_Missoesememorianacional.pdf. Acesso em: 05/03/2014

FURLONG, Guillermo S. J. Músicos argentinos durante la dominación hispánica. Buenos Aires: Huarpes, 1944. 
José Cardiel y Su Carta Relación. Libreria del rio de la Plata. Buenos Aires, 1953. 1962.

Misiones y sus Pueblos de Guaraníes. Buenos Aires: Imprenta Balmes,

Antonio Sepp y su "gobierno temporal" (1732). Buenos Aires: Ediciones Theoria, 1962.

Historia social y cultural del Rio de la Plata: 1536-1810. Buenos Aires: Tipográfica Editora Argentina, 1969.

GODELIER, Maurice. Lo ideal y lo material: Pensamiento, economías, sociedades. Versión castellana de A. J. Desmont. Madrid. Taurus Humanidades, 1989. Título original: L'ídéel et le matériel (1984).

GRIEBELER, Carlos José. A construção do imaginário missionário na correspondência epistolar de Antônio Sepp. 2008. 199f. Tese de Doutorado em Teologia. EST/IEPG, São Leopoldo. 2008. Disponível em: http://tede.est.edu.br/tede/tde_busca/arquivo.php?codArquivo=80. Acesso em: $15 / 04 / 2014$.

GROUT, Donald. J., PALISCA, Claude V. História da música ocidental. Revisão Técnica de Adriana Latino; tradução Ana Luísa Faria. Lisboa: Gradiva, 1994.

HANSEN, João Adolfo. O nu e a Luz: Cartas jesuíticas do Brasil. Nóbrega, 15491558. Revista do Instituto de Estudos Brasileiros, n. 38, p. 87-119, 1995. pp. 108-109. Disponível em: http://www.revistas.usp.br/rieb/article/view/71891. Acesso em: 11/05/2015.

HAUBERT, Máxime. Índios e Jesuítas no Tempo das Missões. Prefácio de Jacques Soustelle; tradução de Marina Appenzeller. São Paulo, Companhia das Letras: Círculo do Livro, 1990. Título original: La vie quotidienne des indiens et jésuites du Paraguay au temps de missions. Librairie Hachette, 1967.

HOLANDA, Aurélio Buarque de. Novo Dicionário da Língua Portuguesa. Rio de Janeiro, Editora Nova Fronteira, 1975.

HOLLER, Marcos Tadeu. Os jesuítas e a música no Brasil Colonial. Campinas: Editora da Unicamp, 2010.

KASSAB, Yara. As estratégias lúdicas nas ações jesuítas, nas terras brasílicas (1549-1597), "para a maior glória de Deus". 2010 Tese de Doutorado em História Social. USP, São Paulo. Ano de obtenção: 2010.

KERN, Arno. Utopia e missões jesuíticas. Porto Alegre: Ed. Universidade/UFRGS, 1994. p. 76.

KIRCHER, Athanasius S.J. Musurgia universalis sive ars magna consoni et dissoni in X. libros digesta. Romae: Ex typographia Haeredum F. Corbellitti, 1650. 2v. Disponível em: http://imslp.org/wiki/Musurgia_Universalis_(Kircher,_Athanasius). Acesso em: 10/06/2015.

LANGE, Francisco Curt. El Extrañamiento de la Compañia de Jesús del Río de la Plata (1767). Los bienes musicales y la constancia de su existencia a través de los inventarios practicados - $1^{\text {a }}$ Parte. In: Revista Musical Chilena. 165 (XL): 4-58, 1986.

Disponível

em: www.revistamusicalchilena.uchile.cl/index.php/RMCH/article/download/13286/13 $561+\& c d=2 \& h l=p t-B R \& c t=c \operatorname{lnk} \& g l=b r$. Acesso em: 05/03/2014.

. El Extrañamiento de la Compañia de Jesús del Río de la Plata (1767). Los bienes musicales y la constancia de su existencia a través de los inventarios practicados - 2a Parte. In: Revista Musical Chilena. 176 (XLV); 42-56, 1991. Disponível

em: www.revistamusicalchilena.uchile.cl/index.php/RMCH/article/viewFile/13909/141 
$96+\& c d=7 \&$ hl $=$ pt-BR\&ct=clnk\&gl=br. Acesso em: 05/03/2014

LEITE, Serafim S. J. História da Companhia de Jesus no Brasil. 10 v. in 4. $2^{\text {a }}$ Edição. São Paulo. Edições Loyola, 2004.

LIMA, Tânia S. Um peixe olhou para mim: O povo Yudjá e a perspetiva. São Paulo: Editora UNESP: ISA: Rio de Janeiro: NuTL. 2005.

MAHN, A. T. The influence of Sea Power uppon History, 1660-1783. Cambridge University Press, 2001.

MAYR, Johann. Anton Sepp: Ein Südtiroler im Jesuitenstaat. Verlagsnstalt Athesia, Bozen, 1988. 480p.

MARTINS, Maria Cristina Bohn. A Festa Guarani nas Reduções: Perdas, permanências e recriação. Tese (Doutorado). Instituto de Filosofia e Ciências Humanas - PPGH - PUCRS. Porto Alegre, 1999.

MELIÀ, Bartomeu. El guarani conquistado y reduzido: ensayos de etnohistoria. Asunción: Universidad Católica, 1988.

As missões jesuíticas nos sete povos das missões: depoimento [18 de setembro, 2006]. São Leopoldo: Revista do Instituto Humanitas Unisinos. Entrevista concedida a IHU on-line. Disponível em: http://www.ihuonline.unisinos.br/index.php?option=com_content\&view=article\&i $\mathrm{d}=407 \&$ secao $=196$. Acesso em: 04/03/2014.

MICELI, Paulo. O ponto onde estamos: viagens e viajantes na história da expansão e da conquista (Portugal, século XV e XVI). 4. ed. - Campinas, SP: Editora da Unicamp, 2008.

MONTARDO, Deise Lucy. Através do Mbaraka: Música, Dança e Xamanismo Guarani. São Paulo: Editora da Universidade de São Paulo, 2009.

MONTERO, Paula (org.) Deus na aldeia: missionários, índios e mediação cultural. São Paulo: Globo, 2006.

MUSRI, Fátima Graciela. Relaciones conceptuales entre musicologia e historia: análisis de una investigación musicológica desde la teoría de la historia. In: Revista musical chilena. v.53, n. 192. Santiago, 1999. Disponível em: http://www.revistamusicalchilena.uchile.cl/index.php/RMCH/article/viewFile/128 03/13090. Acesso em: 20/04/2015.

NEVES, L. F. B. O Combate dos Soldados de Cristo na Terra dos Papagaios: Colonialismo e Repressão Cultural. Rio de Janeiro, Forense - Universitária, 1978.

PAYRÓ, Roberto P. El Río de la Plata: de colonias a naciones independientes: De Solís a Rosas (1516-1852). Buenos Aires: Alianza Editorial. 2006.

PEREIRA, D. R. "Si soy misionero es porque canto, bailo y toco música": para uma história social da música na Provincia Paracuaria (1680-1768). 2011. $164 f$. Dissertação de Mestrado. PUCRS, Porto Alegre. 2011. Disponível em: http://tede.pucrs.br/tde_busca/arquivo.php?codArquivo=3678. Acesso em: 15/04/2015.

PORTO, Aurélio. História das Missões Orientais do Uruguai. Rio de Janeiro: Imprensa Nacional, 1943. Disponível em: http://ufdc.ufl.edu/AA00011461/00001. Acesso em: 05/03/2014.

PRADO JR., Caio. Formação do Brasil Contemporâneo. São Paulo: Editora Brasiliense, 1976.

PREISS, Jorge Hirt. A música nas missões jesuíticas nos séculos XVII e XVIII. Porto Alegre: Martins Livreiro Editor, 1988.

RABUSKE, Arthur S.J. Pe. Antônio Sepp, SJ - O Gênio das Reduções Guaranis. 2.ed. São Leopoldo: Editora Unisinos, 1979.

Pe. Antônio Sepp, SJ - O Gênio das Reduções Guaranis. 3.ed. São Leopoldo: Editora Unisinos, 2003. 
RAENDEL, Don Michael. The Harvard Dictionary of Music. 4th ed. Cambridge, Massachusetts and London, England. The Belknap Press of Harvard University Press. 2003 (1986).

RIBEIRO, Darcy. As Américas e a civilização: processo de formação e causas do desenvolvimento desigual dos povos americanos. $2^{\mathrm{a}}$ edição. Petrópolis: Vozes, 1977.

RICO CALLADO, Francisco Luis. Conversión y persuasión en el barroco: propuestas para el estúdio de las misiones interiores en la España postridentina. In: Studia histórica. Historia moderna, 24, Ediciones Universidad de Salamanca, 2002, pp. 363-386.

RODRÍGUEZ, Diana Farley. Y Dios se hizo música: La conquista musical del Nuevo Reino de Granada. In: Fronteras de La Historia. Universidad Nacional de Colômbia. Vol. 15-1 / 2010.

SOUTHEY, Robert. História do Brasil. São Paulo, Melhoramentos. 1977.

SZTUTMAN, R. O Profeta e o Principal: A Ação política ameríndia e seus personagens. São Paulo: EDUSP. FAPESP. 2012.

SZARÁN, Luis. Domenico Zipoli (1688-1726): Una vida, un enigma. Nurenberg: Fundación Paracuaria - Missionsprokur S.J., 2005.

SZARÁN, Luis; NESTOSA, Jose (orgs). Música en las Reducciones Jesuíticas de América Del Sur. $2^{\text {a }}$ Edición. Asunción: Missionsprokur, 1999.

WAISMAN, Leonardo. Corelli entre los índios, o Utopia desconstruye Arcádia. In: Concierto Barroco. Estudios sobre música, dramaturgia e historia cultural, ed. J. J. Carreras and M. A. Marín. Logroño, 2004. pp. 227-54. Disponível em: https://www.academia.edu/3814665/Corelli_entre_los_indios_o_Utopia_deconstru ye_Arcadia. Acesso em: 15/10/2012.

- WAISMAN, Leonardo. La contribuición a la música misional em mojos (Bolívia). Revista Memoria Americana: cuadernos de etnohistoria. n.12. Buenos Aires, 2004.

Musica Del Barroco Misional: ¿Un Concepto o un Slogan?. In: WILDE, Guillermo (org.). Saberes de la Conversión - Jesuítas, Indígenas e Impérios Coloniales en las Fronteras de la Cristiandad. Buenos Aires: Editora Sb, 2011.

The Singing Demons Of San Ignacio: Musical Interfaces Between Jesuits and Indians. In: Colloquim on the Department of Music - Columbia University. New York, 15/02/2013. Disponível em: https://www.academia.edu/3815396/The_Singing_Demons_of_San_Ignacio_Musi cal_Interfaces_between_Jesuits_and_Indians. Acesso em: 13/08/2013.

WEISBACH, Werner. El barroco: arte de la contrarreforma. 2.ed. Traduccíon y ensayo preliminar de Enrique Lafuente Ferrari. Madrid, Espasa-Calpe, 1948.

WESTERHAUS, Timothy Paul. The Baroque Requiem Mass at the imperial Habsburg Court in Vienna: musical and historical context, rhetoric, and signification. 2013. Thesis (D.M.A.), Boston University. 2013. Disponível em: http://hdl.handle.net/2144/11085. Acesso em: 05/05/2015.

WILDE, Guillermo. Poderes del ritual y rituales del poder: un análisis de las celebraciones en los pueblos jesuíticos de Guaraníes. In: Revista Española de Antropologia Americana. n. 33. 2003. pp 203-29. Disponível em: http://www.google.com.br/search?q=guillermo+wilde+poderes+del+ritual\&ie=utf$8 \&$ oe $=$ utf- $8 \&$ aq $=$ t\&rls=org.mozilla:en-US:official\&client=firefoxa\&gfe_rd=cr\&ei=RvARU-ifCMai8wfN0oDoAQ. Acesso em: 01/03/2014.

(org. e ed.) Saberes de la Conversión - Jesuítas, Indígenas e Imperios

Coloniales en las Fronteras de la Cristandad. Buenos Aires: Editorial SB, 2011.

WITTMANN, Luisa T. Flautas e maracás: música nas aldeias jesuíticas da América 
Portuguesa (XVI-XVII). 2011. 266f. Tese de Doutorado em História. UNICAMP, Campinas. 2011. Disponível em: www.bibliotecadigital.unicamp.br/document/?down=000802385. Acesso em: 13/04/2015.

ZERON, Carlos. Mission et espace missionnaire: les bases matérielles de la conversion. In: Archives des Siences Sociales des Religions. Paris: édtions EHESS, no 169, janvier-mars 2015, p. 307-334.

ZÍPOLI, Domenico. Misa San Ignacio; Ave Maris Stella; Laudate Dominum; Tantum ergo; Beatus vir; Ad Mariam; Confitebro de (...): recopilación y transcipción Luis Szarán; edicción y coordinacióngeneral Gisela von Thümen. 2. ed. Asunción: Missions Prokur S.J. Nürnberg, 1999. 202p. 